General Geology of the

Mammoth Quadrangle

Pinal County, Arizona
G E O L O G I C A L
S U R V E Y
B U L L E T I N
1218 


\section{General Geology of the}

\section{Mammoth Quadrangle}

\section{Pinal County, Arizona}

By S. C. CREASEY

G E O L O G I C A L S U R V E Y B U L L E T I N 1218

$A$ description of the stratigraphy, structure, and petrology of the rocks in an area that contains deposits of copper, tungsten, and gold

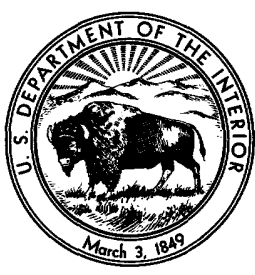




\section{UNITED STATES DEPARTMENT OF THE INTERIOR}

STEWART L. UDALL, Secretary

\section{GEOLOGICAL SURVEY}

William T. Pecora, Director

Library of Congress catalog-card No. GS 67-160 


\section{CONTENTS}

\begin{tabular}{|c|c|}
\hline \multirow{2}{*}{\multicolumn{2}{|c|}{ Abstract }} \\
\hline & \\
\hline roduction_. & 4 \\
\hline ibility & 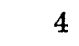 \\
\hline & \\
\hline d acknowledgments & \\
\hline rocks & 7 \\
\hline 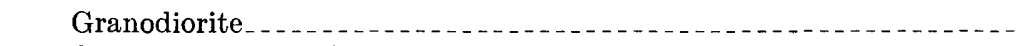 & \\
\hline zonite (Oracle Granite of Peterson, 1938) & 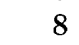 \\
\hline (1) & 10 \\
\hline skite & 12 \\
\hline & 4 \\
\hline ion........... & 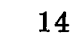 \\
\hline nerate Member and middle member & \\
\hline (n- & 6 \\
\hline - & 10 \\
\hline uartzite & 18 \\
\hline erate Member..... & 19 \\
\hline (2n- & 20 \\
\hline ber & 21 \\
\hline 的 & 22 \\
\hline 品 & 22 \\
\hline 思- & 26 \\
\hline er & 27 \\
\hline Iember & 29 \\
\hline er & 30 \\
\hline - & 33 \\
\hline - & 34 \\
\hline 思 & 34 \\
\hline 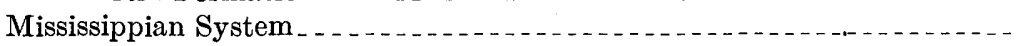 & 37 \\
\hline 㐌- & 37 \\
\hline ian Systems_... & 41 \\
\hline - & 41 \\
\hline (1-1 & 41 \\
\hline $\mathrm{n}_{\mathbf{n}} \ldots$ & 41 \\
\hline - & 45 \\
\hline (?) Systems & 48 \\
\hline ( & 0 \\
\hline 县 & 49 \\
\hline rhyodacite & \\
\hline 只 & 58 \\
\hline - & 58 \\
\hline Systems _.... & 60 \\
\hline $\mathrm{te}$ & 60 \\
\hline
\end{tabular}




\begin{tabular}{|c|c|}
\hline \multirow{2}{*}{\multicolumn{2}{|c|}{ Quaternary System }} \\
\hline & \\
\hline Gravels & 4 \\
\hline Alluvium & 65 \\
\hline ocks of unknown age-granite & 66 \\
\hline 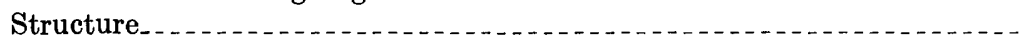 & 6 \\
\hline of principal structural events & 66 \\
\hline es in the Mammoth quadrangle & 68 \\
\hline ediments & 78 \\
\hline - & 79 \\
\hline sits . . . . . . . & 80 \\
\hline nmoth) mine & 80 \\
\hline 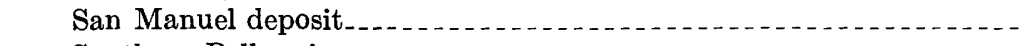 & 81 \\
\hline - - & 82 \\
\hline ect & 84 \\
\hline - & 84 \\
\hline tures_-_- & 84 \\
\hline .............. & 85 \\
\hline 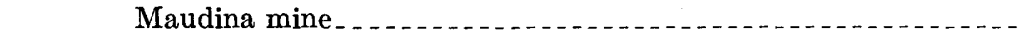 & 85 \\
\hline nine & 86 \\
\hline - & 87 \\
\hline endations & 87 \\
\hline ces cited. & 88 \\
\hline$--1-1-1-1-1-1$ & 91 \\
\hline
\end{tabular}

\section{ILLUSTRATIONS}

Plate 1. Geologic map._... In pocket

2. Geologic maps of Maudina and Morning Star tungsten mines In pocket

Figure 1. Index map of Arizona

2-5. Photograph of :

2. Typical Barnes Conglomerate Member of the Dripping Spring Quartzite.

3. Typical Three C Member of the Abrigo Formation.

4. Crossbedded sandy dolomite in the Peppersauce Member of the Abrigo Formation. ........

5. Chip or edgewise conglomerate in the Peppersauce Member of the Abrigo Formation........ 32

6. Plan and sections of Peppersauce Cave, Nugget Canyon.-- $\quad 40$

7. Geologic sketch map of Southern Belle gold mine....... 83 


\title{
GENERAL GEOLOGY OF THE MAMMOTH QUADRANGLE PINAL COUNTY, ARIZONA
}

\author{
By S. C. Creasey
}

\begin{abstract}
The Mammoth quadrangle is in southeastern Arizona about $\mathbf{3 0}$ miles northeast of Tucson on the north slope of the Santa Catalina Mountains. It is along the junction of bedrock and valley fill of the San Pedro Valley, which lies to the east. Bedrock is largely limited to the western third of the quadrangle, and locally valley fill extends across the entire quadrangle. The broad wash of the San Pedro River cuts diagonally northwestward across the quadrangle and is the dominant topographic feature. Altitudes range from 7,577 feet on Rice Peak in the southwest corner of the quadrangle to 2,300 feet at the point where the San Pedro River crosses the northern boundary of the quadrangle. Local relief, however, in all but the southeast corner is gentle, and most of the quadrangle is a series of moderately dissected surfaces dipping gently toward the San Pedro River.

Bedrock in the quadrangle ranges in age from Precambrian to Pleistocene and includes intrusive, extrusive, and sedimentary rocks. The oldest Precambrian rocks are quartz monzonite, granodiorite, and subordinate amounts of alaskite, aplite, and diabase. The quartz monzonite and granodiorite are coarse-grained deep-seated plutonic rocks. The alaskite, aplite, and diabase form dikes and small irregular intrusives that cut the older granitic rocks; their outcrop area is small in comparison to the granitic rocks.

The younger Precambrian Apache Group, which is about 850 feet thick, unconformably overlies the granitic rocks in the southeast corner of the map area. From old to young, the Apache Group here consists of the Pioneer Formation and the Dripping Spring Quartzite.

The Pioneer Formation comprises three members: the Scanlan Conglomerate Member, the middle member, and the upper member. The Scanlan Conglomerate Member, 2-6 feet thick, consists of cobbles and pebbles of vein quartz, quartzite, and jasper. It grades upward into the middle member. The middle member, $80-$ 135 feet thick, consists of coarse-grained sandstone; the upper member, 365 feet thick, consists of tuffaceous sandstone and slabby maroon to purple slate.

The Barnes Conglomerate Member, the basal member of the Dripping Spring Quartzite, disconformably overlies the Pioneer Formation. It is a marker bed averaging about 50 feet thick that commonly stands as a rib well above the adjacent country. It consists of well-rounded boulders and cobbles of quartz, quartzite, and scarce jasper.

The Dripping Spring Quartzite comprises three members: the Barnes Conglomerate Member, cited above; a middle member, 204 feet thick, consisting of red medium-bedded feldspathic quartzite; and an upper member, 89 feet thick, consisting of thin-bedded slabby quartzite and interbedded shale.
\end{abstract}


Following the accumulation of the Apache Group, but before deposition of any Paleozoic rocks, the Apache Group, particularly the upper member of the Pioneer Formation, was intruded by masses of stratiform diabase $300-600$ feet thick.

Paleozoic rocks aggregating 1,935 feet in thickness unconformably overlie the Apache Group. The oldest of these rocks is the crossbedded Bolsa Quartzite of Middle Cambrian age, which is about 400 feet thick. It grades upward into 740 feet of shales, thin-bedded sandstone, and impure limestones of the Abrigo Formation, of Middle and Late Cambrian age, which consists of three members. Listed in order of deposition, these are the Three C, Southern Belle, and Peppersauce Members. The Devonian Martin Formation disconformably overlies the Abrigo. It consists of two impure dolomite units separated by a pink finegrained limy sandstone unit. A 6-foot orthoquartzite bed separates the Martin from the overlying Mississippian Escabrosa Limestone, a massive thick-bedded cliff-forming limestone. Pennsylvanian and Permian limestones are missing, except for about 100 feet of the Naco Limestone in an inlier; but to judge by their distribution in adjacent areas, their absence is due to erosion rather than to nondeposition.

The top of the Paleozoic section is marked by an unconformity that probably spans the Triassic, Jurassic, and at least part of the Cretaceous Periods. This erosional period was interrupted by the deposition of more than 2,000 feet of fresh-water conglomerates and graywackes of the American Flag Formation of Cretaceous(?) age, which overlies the Paleozoic rocks by a small angular unconformity.

The first igneous activity subsequent to the Precambrian was the intrusion of granodiorite porphyry into the American Flag Formation, Paleozoic rocks, and older rocks. The San Manuel porphyry copper deposit is largely in the granodiorite porphyry and may be related genetically to this period of igneous activity.

Erosion followed the intrusion of the granodiorite porphyry. It exposed the granodiorite porphyry and supplied material to the Cloudburst Formation, a terrestrial sequence of interbedded fanglomerates and highly altered latitic flows and flow breccias. The Cloudburst is Late Cretaceous or early Tertiary. Rhyolitic to rhyodacitic volcanic plugs intrude the Cloudburst Formation. Their age is not known but is probably early Tertiary. In part at least, these plugs are older than the middle Tertiary volcanic rocks in the Galiuro and Winchester Mountains along the east side of the San Pedro Valley.

In the Pliocene and perhaps in the Pleistocene, fluviatile fanglomerates and conglomerates and lacustrine marls of the Gila Conglomerate accumulated in a broad basin (San Pedro Valley) formed during the Basin and Range deformation. These fluviatile and lacustrine deposits cover at least two-thirds of the map area.

Eventually, drainage was established through the basin, and the Gila Conglomerate was deeply eroded. During at least two periods, the erosion was sufficiently static for extensive pediments to form. Further erosion has reduced these pediments to scattered patches of gravel and lowered the flood plain of the San Pedro River to roughly 50 feet or more below the level of the adjacent country. The river bed itself is cut 10-20 feet below the flood plain; apparently, the river is in a period of accelerated erosion.

The oldest Precambrian structures in the map area are sheared zones and joints, many occupied by dikes, in the quartz monzonite and granodiorite. Younger Precambrian deformation includes inflation of the Apache Group, due to intrusion of stratiform diabase, foliation in the Pioneer Formation, and uplift and subsidence of two ages marked by the pronounced unconformity at the top of the Apache Group. The foliation can most likely be attributed to the diabase 
intrusion. At least 2,000 feet of rocks was removed during the two erosional periods.

The entire Paleozoic section appears conformable, despite time breaks between some of the formations. Apparently, gentle uplifts accompanied by a minimum of erosion were followed by gentle subsidence.

The rocks do not record any strong deformation or igneous activity during the Triassic or Jurassic. Although the record is too incomplete to have much meaning, the small angular discordance between the Paleozoic rocks and the Cretaceous(?) American Flag Formation does not suggest any intervening structural paroxysms.

Post-Early Cretaceous and pre-Pliocene deformation, chiefly faulting, produced the major structures in the map area. Thrusts, reverse faults, and strike-slip fault formed during this period. Thrust faults moved the Cloudburst Formation over Precambrian granitic rocks and Escabrosa Limestone over the American Flag Formation. A complementary set of high-angle reverse faults formed in the upper plate of the thrust at the base of the Cloudburst Formation. Presumably, the reverse faults are related to the thrust.

The Mogul, the dominant fault in the map area, is a right-lateral normal fault. The offset parallel to the trace of the Mogul fault is probably about 10 miles, as suggested by the inferred displacement of Paleozoic rocks. The stratigraphic throw where the American Flag Formation contacts the fault is a minimum of 5,000 feet. Numerous subsidiary faults are adjacent to the Mogul; they seem to be related to the Mogul and probably are of the same age. Other faults of this age probably are unrecognized, owing to renewed movement during younger deformation.

The granodiorite porphyry was intruded in Cretaceous (?) time following the accumulation of the American Flag Formation. The largest mass, which is in the southeast corner of the map area, pushed the rocks aside, arching the Paleozoic rocks toward the east and west. Subsequently, it was weakly foliated, presumably at the same time as the movement on the Mogul fault. Elsewhere, granodiorite porphyry dikes follow east-northeast fractures, which may have formed during this period.

The Basin and Range deformation of Pliocene and younger age is responsible for the gross pattern of the ranges and basins in southeastern Arizona. In the Mammoth quadrangle, the San Pedro Valley, the Black Hills, and the Santa Catalina Mountains are products of the Basin and Range deformation. Normal faults are the dominant structures. Some of these are well exposed, whereas others, which are inferred, are concealed beneath the fill in the San Pedro Valley.

Movement along the Mammoth and San Manuel normal faults elevated the Black Hills in the northwest corner of the map area. The Mammoth fault, which comprises several strands, for the most part bounds the Black Hills on the east. The principal strand of the fault has a normal dip-slip displacement of about 700 feet in the St. Anthony (Mammoth) mine.

The San Manuel fault bounds the Black Hills on the southwest. It is a normal right-lateral fault with a dominant right-lateral component estimated at 10,000 feet or more. Although movement on the fault displaced the Gila Conglomerate and thus is post-Pliocene, initial movement may have occurred during the post-Early Cretaceous and pre-Pliocene period of deformation when the Mogul fault was most active. The Mogul fault moved only slightly after the San Pedro Valley was formed; near the Three C Ranch, the vertical separation on the base of the Gila Conglomerate is estimated to be 50 feet. 
In the northern part of the map area the Mammoth and San Manuel faults offset the Gila Conglomerate, whereas southward they are overlapped by the Gila. These relations show that faulting and sedimentation were contemporaneous. Locally, elsewhere in the quadrangle, the contacts between marl and fanglomerates of the Gila are remarkably straight and are parallel to the Mammoth fault. Such contacts may mark buried range-front faults.

The map area contains prominent deposits of copper, lead, zinc, molybdenum, vanadium, tungsten, gold, and silver. The San Manuel porphyry copper deposit is in the northeastern part of the map area. It consists of sulfides, chiefly chalcopyrite and pyrite, disseminated in Cretaceous(?) granodiorite porphyry and Precambrian quartz monzonite. The altered zone that contains the ore is about $8,000-9,000$ feet wide and more than 9,300 feet long; the long dimension strikes about $\mathrm{N} .80^{\circ} \mathrm{E}$. The ore contains about 0.8 percent combined oxide and sulfide copper. Only summaries of the deposit are given in this report because of two earlier reports by the U.S. Geological Survey. The St. Anthony (Mammoth) deposit, which is a short distance northeast of the San Manuel, is a complex vein deposit that produced gold, silver, molybdenum, and vanadium from the oxidized part of the vein and lead and zinc from the unoxidized part. Total production between 1881 and 1952 was about 1,900,000 tons of ore.

The Morning Star and Maudina are tungsten deposits in a silicified and sheared fault block of Escabrosa Limestone adjacent to the Mogul fault. The ore mineral is scheelite, and it is restricted to well-defined shoots in the silicified zones that seem to be controlled by structures related to the Mogul fault. Total production of both deposits from 1908 to 1944 is probably about 17,700 units of $\mathrm{WO}_{3}$.

The Southern Belle mine and Mary West prospect are small mines within the map area. The Southern Belle contained gold-quartz veins in the Dripping Spring Quartzite. Unfortunately, the production is unknown. The Mary West prospect was explored for base metals along a quartz vein lying between the middle and upper members of the Pioneer Formation. The mine has no record of production.

\section{INTRODUCTION}

\section{LOCATION AND ACCESSIBILITY}

The Mammoth quadrangle is in southeastern Arizona, about 30 miles northeast of Tucson and on the north slope of the Santa Catalina Mountains. It is bounded by lat $32^{\circ} 45^{\prime}$ and $32^{\circ} 30^{\prime}$ and long $110^{\circ} 45^{\prime}$ and $110^{\circ} 30^{\prime}$ (fig. 1).

Access to most of the quadrangle is good. Arizona State Highway 77 crosses the northwestern part of the quadrangle, and a paved road, too new to be shown on the geologic map, connects the San Manuel mine to the town of San Manuel, which is in and around sec. 32, T. 9 S., R. 17 E. The Mount Lemmon road, an improved dirt road extending from Oracle to the summit area of the Santa Catalina Mountains, traverses the southwest corner of the quadrangle. Good dirt roads, built and maintained by the local stockmen and by Pinal County, are strategically placed to serve the less accessible country. In addition, the larger washes and gulches, where not obstructed by fences, are natural access roads for four-wheel-drive vehicles. 


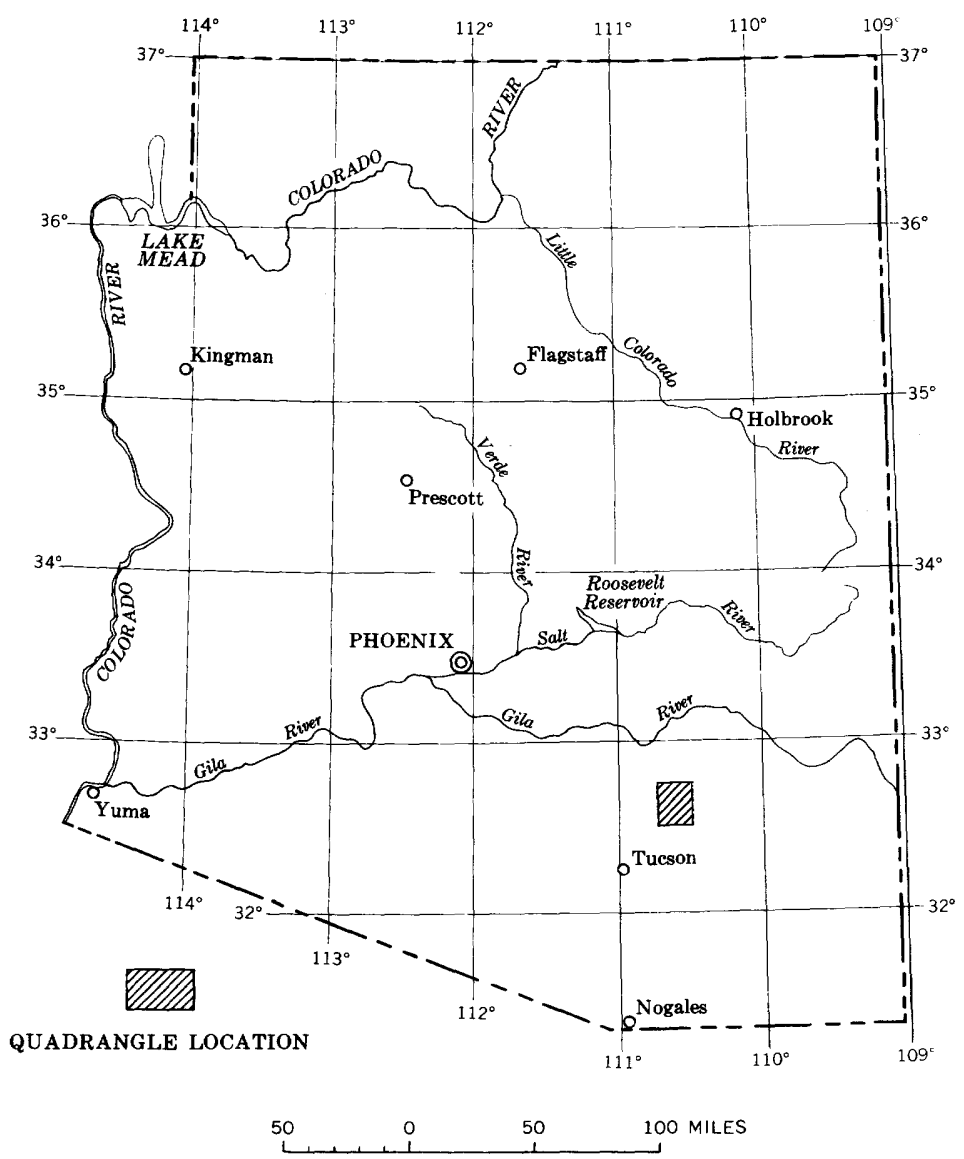

Figure 1.-Index map of Arizona showing the location of the Mammoth quadrangle.

Two roughly parallel lines of the San Manuel, Arizona, Railroad Co., which is owned by the San Manuel Copper Corp., lie within the area. One line, 8 miles long, connects the mine to the mill and smelter adjacent to the San Manuel townsite; the other, 29 miles long, extends from the mill and smelter to Hayden where it joins the Southern Pacific Railroad. The line to Hayden transports the copper anodes and freight outbound, and limestone and quartzite and freight inbound to the plant at San Manuel.

Mammoth, which lies along the San Pedro River, and San Manuel are the two towns within the quadrangle (pl. 1). Originally, Mammoth was the site of the stamp mill for gold ores mined from the Mammoth mining camp. Old mining camps commonly continue to 
survive long after logic predicts their end; Mammoth was such a camp. It somehow survived the lean years when the mines were closed and somehow survived when the milling was moved to the mines. Apparently, it was sustained by the stockmen and the scattered residents in the valley. Arizona State Highway 77 passes through the town; the agricultural development of the San Pedro Valley has now begun; and many dollars paid out by the San Manuel enterprise are exchanged for supplies, services, and recreation in Mammoth. All of these have combined to produce a prosperous and growing community.

San Manuel is the new, modern town built since about 1951 to house the people working in the San Manuel mine, mill, and smelter, and in supporting services. It contains many facilities: shopping, educational, recreational, and medical.

Oracle, which is a small but growing settlement built around a general store and post office, is about 2 miles west of the map area. Winkelman and Hayden are in the San Pedro Valley about 20 miles north of the area. They are towns largely supported by people engaged in the mining, milling, and smelting of ores from the Ray porphyry copper deposit.

\section{PHYSICAI FEATURES}

Altitudes in the map area range from about 2,300 to 7,577 feet. The lowest point is where the San Pedro River leaves the quadrangle along the northern border; the highest point is Rice Peak, which is in the southwest corner. Local relief is gentle, except for the southwest corner. Here altitudes of about 4,500 feet near the Mogul fault increase steadily to more than 7,500 feet within a distance of about 3 miles, and the intervening area is deeply dissected by steep-walled canyons.

The large part of the quadrangle underlain by the Gila Conglomerate is a series of moderately dissected surfaces sloping gently toward the San Pedro River, which is well below the general level of the surrounding country. Lithologic differences in the Gila have a marked effect on the slope and dissection of the surfaces. Slopes cut on more resistant indurated fanglomerate are on the order of 200-250 feet per mile, in contrast to slopes of 150-180 feet per mile cut on less resistant marls and silts of lake beds. The bed of Copper Creek slopes at 170 feet per mile over the fanglomerate, but only 100 feet per mile over the lake beds. The soft unconsolidated marls erode easily, and canyons cut in them have wide alluviated streambeds flanked by cliffs rising several hundreds of feet, whereas the fanglomerates erode to steep slopes which locally give way to narrow slotlike canyons. In some places where Copper Creek cuts the fanglomerate, the canyon 
is not more than 10 feet wide for an estimated depth of 100 feet. These contrasts result in a pronounced physiographic change at the contact between the two rock types, and the contact stands out as a pronounced line on the topographic map.

The flood plain of the San Pedro River, which is as much as 1 mile across, is deeply entrenched, the surrounding gravel benches commonly rising 100 feet above the flood plain. The riverbed itself is entrenched from 5-15 feet below the flood plain. The rich soil and level surface of the flood plain are favorable for farming where ample ground water is available, and irrigated cotton fields and pastures flank the river here and there.

\section{FIELDWORK AND ACKNOWLEDGMENTS}

The fieldwork on the Mammoth quadrangle consumed about 15 manmonths. From September 1954 to January 1955, Robert E. Davis and S. C. Creasey mapped the northwest quarter of the quadrangle on a scale of $1: 24,000$. This map accompanied by a description of the San Manuel ore deposit was published as a separate report. Fieldwork was resumed on the remainder of the quadrangle in 1959 by $\mathrm{E} . \mathrm{H}$. Pampeyan and S. C. Creasey and was completed in 1960, only a part of each year being spent on field mapping.

Mr. Virgil Mercer, Jr., manager of the Three C Ranch, generously supplied domestic water and storage for a trailer at the ranch during the off season. In addition, he kindly permitted access to all parts of the ranch. Other ranchers and residents of the area also were courteous and helpful.

\section{PRECAMBRIAN ROCKS}

\section{GRANODIORITE}

The granodiorite crops out over about 4 square miles in the northwest corner of the quadrangle. It underlies a somewhat larger area, but is locally covered by a thrust plate of the Cloudburst Formation.

The granodiorite is a light-colored medium-grained hypidiomorphic granular rock. The color index is about 13 . Locally, northeastand northwest-trending shear planes and joints are prominent and are commonly marked by aplitic and diabasic dikes. Other local trends of minor shear planes and joints were noted, and where well developed, they were recorded by a symbol. The rock, however, is by no means gneissic.

The granodiorite is everywhere deeply weathered-weathered to such an extent that fresh specimens from which thin sections can be made are scarce. Relatively fresh granodiorite was obtained from the dump of the Tar mine and from a few scattered outcrops, but 
most of the granodiorite in surface outcrops is sufficiently rotten to be crushed by hand.

The granodiorite is composed of quartz, plagioclase $\left(\mathrm{An}_{30} \pm 5\right)$, $\mathrm{K}$-feldspar, biotite, and hornblende. Accessory minerals are leucoxene, magnetite, and zircon; secondary constituents are carbonate, chlorite, and sericite. The plagioclase and mafic minerals are subhedral; the K-feldspar is anhedral and occurs (1) interstitial to the quartz, plagioclase, and mafic minerals and (2) as minute blebs included in the plagioclase, probably owing to exsolution. Much of the plagioclase is argillized; some crystals are completely altered, whereas others are altered in irregular patches or differentially altered with the greatest alteration in the core. The average, in volume percent, of two modes from the granodiorite is: quartz 23, plagioclase $\left(\mathrm{An}_{30}\right) 51$, K-feldspar 10, mafic (biotite plus hornblende) 13 , accessories 1 , carbonate 1 , and other 1 .

The age of the granodiorite is older Precambrian. The basis for this age is discussed on page 10 .

\section{QUARTZ MONZONITE (ORACLE GRANITE OF PETERSON, 1938)}

The quartz monzonite is the most extensive rock unit in the quadrangle, other than the Gila Conglomerate. It crops out in the western half of the quadrangle sporadically in large and small patches from the southern to the northern quadrangle boundaries. Undoubtedly, much of the Gila Conglomerate west of the San Pedro River overlies quartz monzonite, and from underground exposures in the Mammoth (St. Anthony) mine and from a window in the thrust plate at the base of the Cloudburst Formation, too small to show on plate 1, much of the footwall of the thrust is quartz monzonite.

The quartz monzonite is a coarse-grained porphyritic rock; it has a color index ranging from 5 to 15 and probably averaging about 10 . As in the granodiorite, deformation locally produced joints and sheared zones, but the rock is not gneissic. Most of these structures trend northeast and northwest, and many are occupied by aplitic and diabasic dikes.

The quartz monzonite away from the foothills of the Santa Catalina Mountains is deeply weathered, and fresh rock cannot be obtained from surface outcrops. From about the Mount Lemmon road to the western edge of the quadrangle, however, erosion stripped the weathered mantle and exposed fresh rock. Because of the pronounced jointing, these exposures of fresh rock tend to be in picturesque rounded boulderlike outcrops that rise as much as 20 feet above the general level of the countryside.

The quartz monzonite consists of phenocrysts of microperthite and $\mathrm{K}$-feldspar, as.much as 3 inches long parallel to the side pinacoid, set 
in a medium-grained hypidiomorphic granular matrix. The phenocrysts are pink, whereas the matrix feldspar (both plagioclase and $\mathrm{K}$-feldspar) is white. The bulk of the $\mathrm{K}$-feldspar is in the phenocrysts, but that in the matrix occurs interstitial to the quartz and plagioclase. In the specimen studied, the plagioclase was saussuritized, but whether this is characteristic of all the quartz monzonite was not determined. Accessory minerals are sphene, zircon, and apatite.

The following table gives a chemical analysis, norm, and four modes for the quartz monzonite.

Chemical, normative, and modal composition of the quartz monzonite

[Chemical analysis from Schwartz, 1953, p. 7; analyst: Charlotte M. Warshaw]

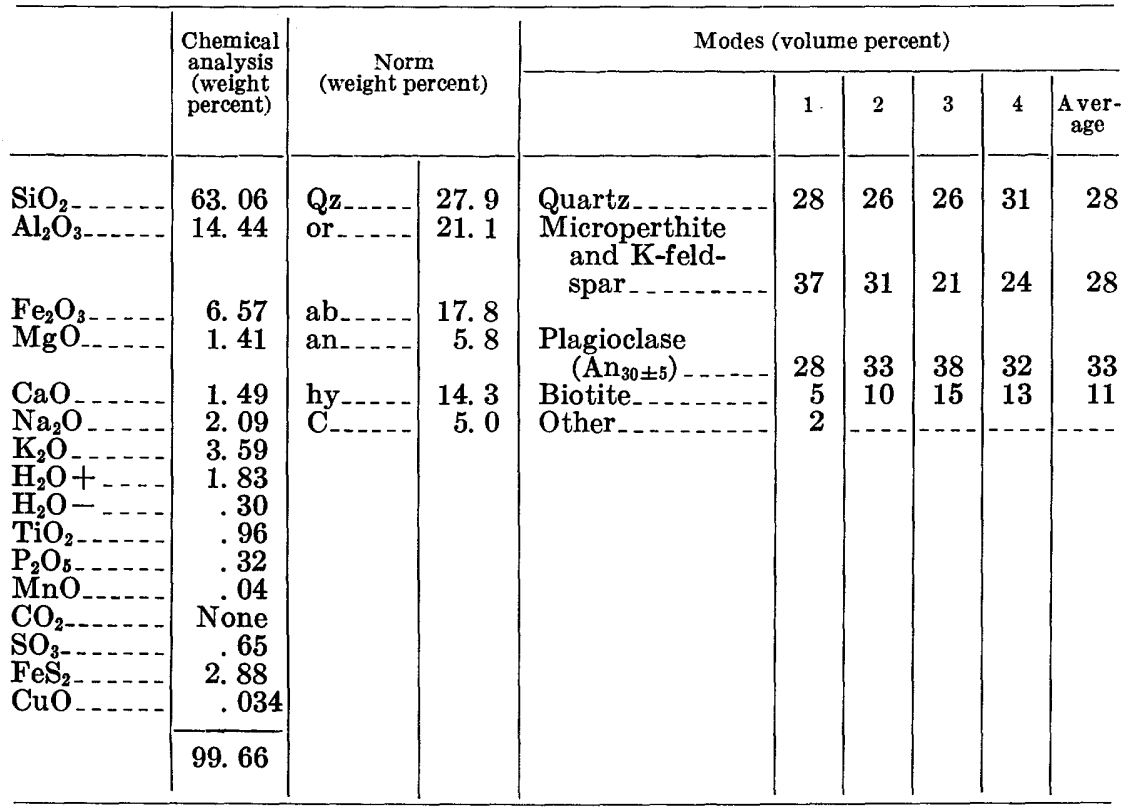

1. From Mammoth (St. Anthony) mine, Peterson, 1938, p. 8-9.

2. From the dump of the Tar mine, Mammoth quadrangle.

3. From near Oracle, Ariz.

4. From near Oracle, Ariz.

The analysis is of an altered sample of quartz monzonite (Schwartz, 1953$, p. 7$)$, and the partial norm calculated from it assumes that all the iron not in sulfide is in the mafic silicates and ilmenite rather than magnetite. The difficulty in measuring an accurate mode is increased by the porphyritic texture and the coarse grain size. The variations in the modes therefore may be due either to errors in measurement or to actual differences in the rock from place to place. Nevertheless, both the modes and the norm indicate the rock is a quartz monzonite. 
The quartz monzonite is older Precambrian. South of the Mogul fault, the Scanlan Conglomerate Member, which is the basal unit of the younger Precambrian Apache Group, rests unconformably on the quartz monzonite. This unconformity is profound; elsewhere, it separates the Pinal Schist, an intensely deformed metamorphic formation, from the Apache Group.

The Precambrian age of the quartz monzonite determined by geologic relations is supported by isotopic age determinations. T. W. Stern, of the U.S. Geological Survey, obtained three lead-alpha ages for the quartz monzonite from zircons concentrated from churn-drill cuttings obtained by G. M. Schwartz during exploration on the San Manuel ore deposit. The individual ages, in millions of years, are $1,200 \pm 130,1,320 \pm 150$, and $1,250 \pm 140$; the average is about 1,250 \pm 140 million years. Giletti and Damon (1961) obtained an age of 1,450 million years for biotite from the quartz monzonite using the rubidium-strontium method and a half life of $50 \times 10^{9}$ years for $\mathrm{Rb}^{87}$. The correct figure for the half life of $\mathrm{Rb}^{87}$ is in dispute; $50 \times 10^{9}$ years is a geologically determined figure, whereas $47 \times 10^{9}$ is the figure determined by liquid scintillation counting. If $47 \times 10^{9}$ years for the half life is used instead, the age is reduced to 1,350 million years, which is reasonably close to the average lead-alpha age.

Unequivocal evidence for the relative ages of the granodiorite and quartz monzonite was not found, but their respective relations to the aplite and alaskite suggest that the quartz monzonite is younger. The aplite and alaskite appear to be temporally and genetically related to the quartz monzonite (see p. 12). Yet dikes of aplite cut the granodiorite as well as the quartz monzonite, which implies that the granodiorite was emplaced before the quartz monzonite.

\section{DIABASE}

Diabase dikes and sills are plentiful wherever Precambrian rocks crop out. In the southwest corner of the quadrangle, large stratiform diabasic intrusions cut the Apache Group, and from the Mogul fault northward along the western margin of the quadrangle to its northern border, diabase dikes cut the Precambrian granitic rocks.

The diabase intruded all formations and members in the Apache Group except the Barnes Conglomerate Member of the Dripping Spring Quartzite; it cut the lower member of the Pioneer Formation and spread out in large sill-like masses from 300-600 feet thick in the upper member. In the Dripping Spring Quartzite, it crosscuts the middle member, but spread into stratiform intrusives along the contact of the middle and upper members and within the upper member. These stratiform intrusive sheets dilated the Apache section. At no place is there an indication of assimilation of country rock. 
The diabase dikes in the granitic rocks occur both in swarms and separately. The dikes trend northeast and northwest, but the northwest trend predominates; no age distinction was recognized between the two. The longest continuous diabase dike crops out for $41 / 2$ miles, and the swarm of which it is a part crops out for $61 / 2$ miles before leaving the western boundary of the quadrangle. The dikes range in width from a few feet to about 1,500 feet. Many of the dikes shown on the geologic map are less than 50 feet wide and they are therefore shown somewhat diagrammatically.

The diabase ranges from medium gray to nearly black, corresponding to a range in color index of from 43 to 75 . It is massive, although the dikes in the granitic rocks mark preexisting structures. The common texture is diabasic; that is, the mafic constituents are interstitial to the lath-shaped plagioclase. Fine-grained granular textures, however, in which the plagioclase is subhedral characterize some of the intermediate and larger masses. The following modes (in volume percent), each a sample from a different diabase dike or sill, illustrate the variation in mineralogy.

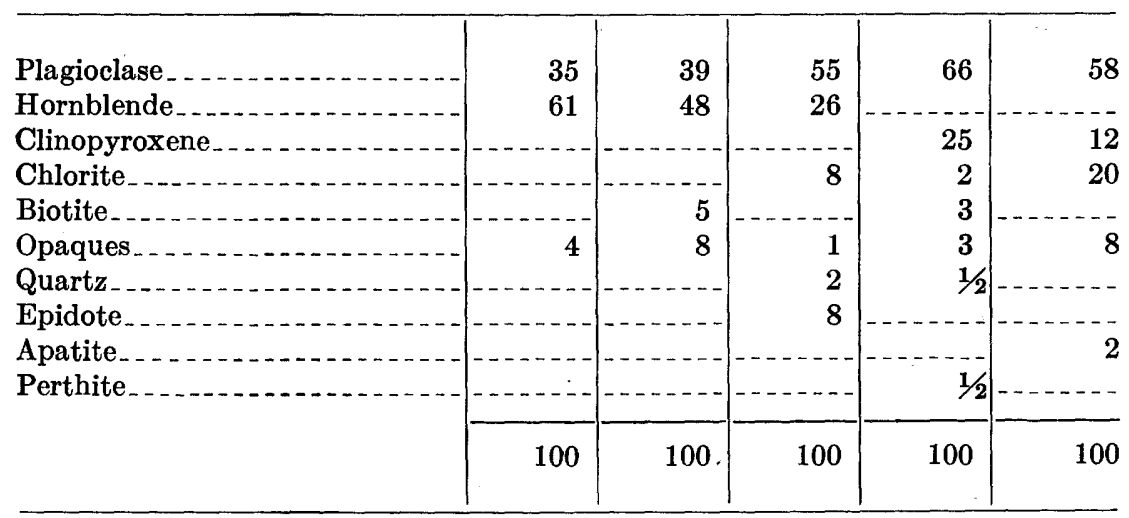

The composition of the plagioclase from two separate dikes is $\mathrm{An}_{35-40}$ and $\mathrm{An}_{50_{ \pm} 3}$, respectively, and to judge by the indices of refraction, the composition in other dikes and sills is also andesine. The plagioclase commonly is altered to sericite, epidote, chlorite, and other undetermined secondary products.

In some masses the predominant mafic mineral is hornblende and in others, clinopyroxene. They commonly are altered to chlorite, and in one dike the clinopyroxene is altered locally to a red-brown biotite, followed by a chloritic alteration. This rock contain some $\mathbf{K}$-feldspar in perthite, which is interstitial to the plagioclase laths. 
The opaque minerals include magnetite, leucoxene, and pyrite. Apatite is the common accessory, and in one sample composes about 2 percent of the rock. One dike contains abundant secondary carbonate, and another abundant secondary epidote.

The intrusive relations of the diabase indicate at least three ages: one Cretaceous (?) and two Precambrian. Some diabase dikes near Red Hill (sec. 35, T. 8 S., R. 16 E.) cut the granodiorite porphyry, which is probably of Cretaceous age, but they do not cut the Cloudburst Formation, which is of late Cretaceous or early Tertiary age. The Precambrian diabase cuts and is cut by the aplite dikes, which probably are satellitic to the Precambrian quartz monzonite. The diabase also forms extensive stratiform intrusive masses in the Apache Group of Precambrian age, and these stratiform masses are truncated by the unconformity at the base of the Paleozoic rocks. The aplite dikes, however, do not cut the Apache Group, and this relation permits distinction of two Precambrian diabases: one older than the aplite and the Apache Group, and the other younger than the Apache Group but older than the Paleozoic rocks. If there are diabases of other ages, they were unrecognized.

Additional support for two ages of Precambrian diabase stems from the interpretation that the quartz monzonite and the aplite dikes are genetically related and hence virtually coeval. Some of the Precambrian diabase dikes cut and are cut by the aplite dikes. Because the quartz monzonite is much older than the Apache Group, the diabase dikes that are cut by the aplite are much older than the large masses of stratiform diabase that intrude the Apache Group, provided, of course, that the relation between quartz monzonite and aplite is correctly interpreted.

\section{APLITE AND ALASKITE}

The aplite and alaskite, which are not differentiated on plate 1, intrude the Precambrian granitic rocks. Aplite oecurs along the western third of the quadrangle wherever Precambrian granitic rocks crop out, but it occurs chiefly from the Mogul fault northward to the quadrangle boundary. The alaskite, however, crops out only in the northwest corner of the quadrangle, in secs. 19 and 20, T. 8 S., R. 16 E.

The aplite occurs chiefly in northwest-trending dikes, and to a lesser extent, in irregularly shaped masses whose long dimension tends to be northwest. A few aplite dikes trend northeast, such as the dike in sec. 8, T. 10 S., R. 16 E., or east-west, such as some of the aplite dikes in the quartz monzonite northwest of the San Manuel deposit. Widths of dikes range from a few feet to perhaps a maximum of 40 feet; most widths, however, are about 10 feet. Their representation 
on the geologic maps is largely diagrammatic, and their widths therefore are exaggerated. The alaskite occurs in an irregularly shaped mass which locally passes into dikelike apophyses.

The alaskite and aplite are light cream or buff, and their color index ranges from 1 to 3 . Locally, they are sheared, but the dominant textures and structures are igneous rather than metamorphic. Fractures and joints, however, are common. The aplite is a fine- to medium-grained rock; the dominant texture is saccharoidal or aplitic, interrupted here and there by graphic intergrowths. Quartz, K-feldspar, albitic plagioclase, and $\mathrm{K}$-feldspar and quartz intergrowths comprise more than 95 percent of the rock. In addition, minor amounts of muscovite, biotite, and magnetite occur.

The alaskite is a medium- to coarse-grained rock. Where the alaskite mass tapers to a dike, the texture becomes aplitic, and the alaskite becomes an aplite, indistinguishable from the aplite dikes. Where the mass widens, however, the grain size coarsens, and the texture becomes porphyritic. Here the alaskite consists of plagioclase and $\mathrm{K}$-feldspar phenocrysts set in a saccharoidal groundmass composed of quartz and K-feldspar. Scattered throughout the alaskite are fibrous hornblende crystals, partly to completely altered to chlorite. Virtually all the plagioclase is phenocrystic, and it is argillized. A mode, in volume percent, of the alaskite consists of 24 percent albitic plagioclase, 43 percent quartz, 31 percent $\mathrm{K}$-feldspar, 1 percent hornblende, and 1 percent chlorite.

The aplite and alaskite seem to be genetically related to the quartz monzonite. The aplite dikes cut the granodiorite and quartz monzonite indiscriminately, but the alaskite is more closely related spatially to the quartz monzonite. In addition, the mineral composition and texture of the alaskite are more like the quartz monzonite. The ratio of quartz to alkali feldspar to plagioclase for the granodiorite, quartz monzonite, and alaskite, respectively, are $23: 10: 51,27: 30: 33$, and $43: 30: 24$. Although all three rocks contain abundant quartz, the closer similarity of the alkali feldspar to plagioclase ratio for the quartz monzonite and alaskite indicates a more similar bulk chemical composition.

Where the alaskite mass is dikelike, the texture is aplitic. But as the dikelike masses wide into the main body of the alaskite, the texture becomes porphyritic, and the rock grades into a porphyritic alaskite and, locally, into a rock that cannot be distinguished megascopically from the quartz monzonite. This transitional change into a rock like the quartz monzonite suggests a close genetic relation between the alaskite and the quartz monzonite. 
The aplite and alaskite are Precambrian, older than the Apache Group but younger than the Precambrian granitic rocks. This age is based on intrusive contacts with the granodiorite, quartz monzonite, and some diabase (see p. 12 for age relations of diabase and aplite). The Apache Group is not intruded by either the aplite or the alaskite.

\section{APACHE GROUP}

\section{PIONEER FORMATYON}

The Pioneer Formation was named by Ransome (1903) from exposures in the northeastern part of the Ray quadrangle, Arizona. Ransome originally called the Pioneer a shale, but subsequent observations have revealed that in many areas it is arenaceous, and commonly tuffaceous. Consequently, later authors also have used Pioneer Quartzite and Pioneer Formation, the latter being the more common designation and the one used here. Willden (1964, p. E13) incorporated the Scanlan into the Pioneer Formation as the Scanlan Conglomerate Bed. This report redefines the Scanlan Conglomerate from a bed to a member, and subdivides the Pioneer Formation into three members: in order of stratigraphic succession they are the Scanlan Conglomerate Member, middle member, and upper member. On plate 1, the Scanlan Conglomerate Member is included with the middle member, and it is described with the middle member in the following text.

The Pioneer Formation occurs in the southwest corner of the Mammoth quadrangle where it crops out continuously for about 4 miles. It overlies Precambrian quartz monzonite (the Oracle Granite of Peterson, 1938) by erosional unconformity. The Barnes Conglomerate Member, the basal conglomerate of the Dripping Spring Quartzite, overlies the Pioneer with apparent conformity, although from relations outside the quadrangle, the contact is known to be a disconformity.

The Scanlan Conglomerate Member of the Pioneer Formation ranges in thickness from 2 to 15 feet. Two sections in the middle member of the formation measured 80 and 135 feet, and the upper member, which is disrupted by diabase intrusion, is 365 feet thick.

\section{SCANLAN CONGLOMERATE MEMBER AND MIDDLE MEMBER}

Ransome (1903) named the Scanlan Conglomerate from exposures at Scanlan Pass near Globe, Ariz., where he considered it a unit wholly underlying his Pioneer Shale. Willden (1964, p. E13), in the Christmas quadrangle, incorporated the Scanlan into the Pioneer Formation 
as its basal unit, the Scanlan Conglomerate Bed. In the Mammoth quadrangle the Scanlan is retained as the basal unit of the Pioneer Formation, but it is here defined as the basal member, the Scanlan Conglomerate Member, to agree in rank with the Barnes Conglomerate Member, the basal member of the Dripping Spring Quartzite.

The Scanlan Conglomerate Member occurs continuously along the base of the Pioneer Formation. On the ridge west of the Mary West mine, the Scanlan ranges from 2 to 6 feet thick, whereas from Oracle Ridge southeastward to the quadrangle boundary, it is appreciably thicker, reaching a maximum of 15 feet and averaging by estimate at least 10 feet.

The pebbles and cobbles in the Scanlan Conglomerate Member are extremely well rounded, and consist of only the most durable rock types: quartz, quartzite, and jasper or chert. At one locality about 90 percent of the cobbles are quartz, about 10 percent quartzite, and less than 1 percent jasper. Certainly, quartz cobbles greatly predominate every where in the Mammoth quadrangle.

The middle member of the Pioneer Formation, which grades into the Scanlan Conglomerate Member, is a white to light-cream thickbedded coarse-grained pebbly sandstone or quartzite. Locally, it exhibits a crude foliation at an angle to bedding. The thickest and best exposed outcrops of the middle member are west of the Mary West mine. Here the member varies in thickness from 80 feet on the north to 135 feet on the south. The rocks consist of thick-bedded coarse-grained feldspathic quartzites containing scattered subrounded pebbles of vein quartz. The pebbles are estimated to comprise less than 10 percent of the rock; here and there they form discontinuous thin pebble beds. The grain size seems to decrease slightly upward. The average grain size by estimate is between 1 and $2 \mathrm{~mm}$; the maximum, exclusive of quartz pebbles, is $5 \mathrm{~mm}$. The maximum pebble size is about $6 \mathrm{~cm}$, but most pebbles are less than $3 \mathrm{~cm}$ in diameter.

The southern part of this exposure contains a 25-foot tuffaceous zone from 60-85 feet above the base. This zone consists of tan thin-bedded tuffaceous sandstone and subordinate amounts of maroon crystal tuff. It is like the upper member of the Pioneer.

An anomalous conglomerate occurs at the top of the middle member from the top of Oracle Ridge southeastward to the quadrangle boundary. This conglomerate, which is as much as 30 feet thick, consists of cobbles and boulders of quartz, quartzite, and red chert. It appears similar to the Barnes Conglomerate Member of the Dripping Spring, for which it could easily be mistaken. 
Locally, the middle member is crudely foliated, and the foliation strikes eastward and dips southward at $30^{\circ}-40^{\circ}$, which is parallel to the pronounced foliation in the fine-grained slates in the upper member. The fine-grained tuffaceous zone within the middle member west of the Mary West mine is as delicately foliated as the upper member; the difference in foliation between the two members is related only to the differences in lithology.

The coarse-grained quartzites consist of subrounded grains of quartz, chert, and $\mathrm{K}$-feldspar set in a microcrystalline matrix of quartz and sericite. Quartz comprises more than 95 percent of the grains. Some quartz grains have overgrowths and sutured edges that interlock with smaller quartz grains; others do not. Some of the grains are aggregates of interlocking crystals, others show strain shadows, and still others are clear. Those that are composite were recrystallized before deposition, and at least some of these are pink in contrast to the others which are clear or gray. K-feldspar, in grains as much as $5 \mathrm{~mm}$ in diameter, is intensely altered to sericite, and based on sericite veinlets that extend from the matrix through the $\mathrm{K}$-feldspar grains, the sericitization occurred after deposition.

\section{UPPER MEMBER}

The upper member is a tuffaceous rock composed of crystal fragments set in a recrystallized matrix derived from ash and pumice fragments. Two rock types predominant; these are closely related in mode of formation, yet are distinctly different in appearance. One is a light-colored crystal tuff that appears much like a fine-grained micaceous sandstone. The other is a maroon to gray slate, formed from recrystallized ash. The characteristic color of the upper member of the Pioneer Formation is maroon or a purplish gray. The bulk of the rocks, however, are light gray or cream colored, commonly with a reddish tint due to a light strain of iron oxide.

The member is typically thin bedded. Bedding is conspicuous, and crossbedding is common, particularly in the coarser grained beds. Beds range in thickness from 1 inch to 3 feet, although one bed near the base of the section is 9 feet thick.

The amount of maroon slate appears to decrease southward from Peppersauce Wash. On the Oracle Ridge south of Rice Peak, maroon slates crop out in only one zone a few feet thick, and the section exposed along the southern edge of the quadrangle is all crystal tuff, except for a few thin partings of slate. Here beds as much as 3 feet thick are common, and the crossbedding is on a much larger scale. 
The beds of crystal tuff consist of crystal fragments set in a matrix of ash and pumice fragments now recrystallized to quartz, sericite, and, locally, feldspar. The largest crystal fragments are approximately $0.6 \mathrm{~mm}$ in diameter, but most are between $0.1 \mathrm{~mm}$ and $0.3 \mathrm{~mm}$.

The crystals listed in order of abundance are quartz, K-feldspar, plagioclase, zircon, apatite, and tourmaline. More than 90 percent by estimate of the crystal fragments are quartz. Presumably, the tourmaline and perhaps the zircon and apatite are exotic; all three compose less than 1 percent of the total.

The fragmental character of the crystals is demonstrated by their angular outlines and erratic shapes, such as sharp-pointed slivers and sharp-pointed crescent-shaped fragments. Here and there, however, subrounded grains. indicate abrasion through water transport. Such foreign grains become more abundant near the base of the member, and the upper member grades into the lower through admixing of the volcanic and terrigenous detritus.

The outline of the original pumice fragments are readily recognized in thin section with plane-polarized light. In general, the pumice fragments were appreciably larger than the crystals.

The pumice and ash recrystallized into a microcrystalline granular aggregate of quartz and sericite with or without feldspar. The individual granules of quartz, which greatly predominate, and feldspar are generally $0.02-0.05 \mathrm{~mm}$ in diameter. The feldspar is intergrown with quartz. Some of the feldspar is so fine grained that it can be identified only as either albite or K-feldspar. Where determined, however, the individual species are albite. Because of their larger average grain size, beds rich in crystal fragments appear to be finegrained feldspathic sandstones, whereas the beds poor in crystal fragments appear to be slates.

The beds composed largely of pumice fragments and ash have a slaty cleavage that is generally not recognized in the crystal tuffs; however, the microscope reveals that the sericite needles in the crystal tuffs are preferentially oriented.

The quartz in the recrystallized pumice forms interlocking aggregates of roughly equant crystals around which anastomose needles of sericite. In some areas of a thin section, the sericite needles form mats that appear to be free of quartz, whereas other areas contain only a few sericite needles dispersed in the granular aggregate of quartz.

The following section was measured westward from the hill marked 5620 , just south of Peppersauce Wash. 
Stratigraphic section of the upper member of the Pioneer Formation

Barnes Conglomerate Member of the Dripping Spring Quartzite:

Pebbles, cobbles, and boulders of well-rounded quartzite set in a quartzite matrix

Upper member of the Pioneer Formation:

6. Tuff, fine- to medium-grained, crystal; in beds from 1 in. to $1 \mathrm{ft}$. thick interbedded with slabby purple slates (tuffs). Crystal tuffs probably predominate, but the slates are more conspicuous. Mica conspicuous in bedding planes. White to light maroon......-.-

5. Tuffs, thin-bedded, fine- to medium-grained, crystal. Poorly exposed. Considerable maroon slate as float, but no outcrops. Some beds of crystal tuff next to diabase appear chalky, owing to alteration

4. Diabase equivalent to about $300 \mathrm{ft}$. of section.

3. Tuff, light-colored, fine-grained, thin-bedded, crystal

2. Slates light-gray to maroon, and subordinate amounts of white to cream thin-bedded crystal tuff-

1. Medium-grained, white, crystal tuff or tuffaceous sandstone. A few interbeds of purple slates (tuffs). Beds 2-3 ft. except for thick, one 9 -ft. bed about $15 \mathrm{ft}$. above the base

Total

Middle member of the Pioneer Formation:

Quartzites, thick-bedded, coarse-grained, feldspathic ; contains scat-

tered subrounded pebbles of vein quartz

\section{ORIGIN}

The source for the quartz, K-feldspar, and quartz pebbles in the Scanlan and middle members is probably the underlying quartz monzonite. The small amount of chert and the recrystallized quartz with sutured contacts came from elsewhere.

The source for the volcanic detritus in the upper member is unknown. Except for the basalt flows at and near the top, volcanics have not been described from the Apache Group. Whatever the source, the volcanic fragments were deposited by water and partly sorted, but the abrasion was not sufficient to round the quartz crystals appreciably.

\section{DRIPPING ISPRING QUARTZITE}

The Dripping Spring Quartzite was named by Ransome (1903) for the Dripping Spring Mountains, which are south of Globe and about 20 miles north of the Mammoth quadrangle. There it is underlain by the Pioneer Shale and overlain by a limestone, later recognized as the Mescal Limestone of the Apache Group; all are of Precambrian age. The Dripping Spring is divided in the Mammoth quadrangle into the Barnes Conglomerate Member (Granger and Raup, 1964) and overlying middle and upper members. 
The Dripping Spring Quartzite is present south of the Mogul fault in the southwest corner of the map area. Here it occurs in fault blocks adjacent to the Mogul fault, and in continuous outcrop starting about a mile south of the fault and continuing south to southeast for about 4 miles to the boundary of the area.

The Dripping Spring Quartzite overlies the Pioneer Formation in apparent conformity, and is disconformably overlain by the Bolsa Quartzite of Cambrian age. The Barnes Conglomerate Member marked the beginning of sedimentation that continued uninterrupted until all the Dripping Spring accumulated. Although the Dripping Spring and Bolsa Quartzites have similar attitudes, the disconformity between them marks a period during which erosion stripped the land to expose medium-grained diabase in large stratiform intrusive masses. Certainly, an appreciable amount of the upper part of the Dripping Spring Quartzite and probably other rocks was removed. In the Holy Joe Peak quadrangle, which joins the Mammoth on the north, M. H. Krieger (oral commun., March 1961) has demonstrated that at least a thousand feet of Dripping Spring and Troy Quartzites covered stratiform diabase masses at the time of their intrusion.

\section{BARNES CONGLOMERATE MEMBER}

The Barnes Conglomerate was named by Ransome (1903) from the good exposures on Barnes Peak, which is about 12 miles northwest of Globe, Ariz.

The Barnes Conglomerate Member (Granger and Raup, 1964, p. 16-22) is present south of the Mogul fault in the southwest corner of the map area. Except for minor offsets by small faults, it crops out continuously for about 5 miles. In addition, six small faulted segments of Barnes are adjacent to the Mogul fault in secs. 17 and 18, T. 10 S., R. 16 E.

The Barnes is a marker bed. It crops out strongly everywhere and commonly forms a distinctive ridge standing as much as 50 feet above the general level of the adjacent rocks.

The lithology of the Barnes differs markedly from that of the overlying middle member of the Dripping Spring Quartzite, but the contact is gradational. The Barnes disconformably overlies the Pioneer Formation, but within the map area the contact appears conformable.

A section of the Barnes Conglomerate Member, 57 feet thick, was measured in Peppersauce Wash along with the overlying members of the Dripping Spring. Although no other sections were measured, $50-60$ feet is thought to be the average thickness, and at no place did the thickness appear to be as much as 100 feet.

The Barnes consists of pebbles, cobbles, and boulders of wellrounded quartz, quartzite, and jasper set in a quartzite matrix, figure 2. Both quartz and quartzite clasts are abundant, but chert is scarce. 


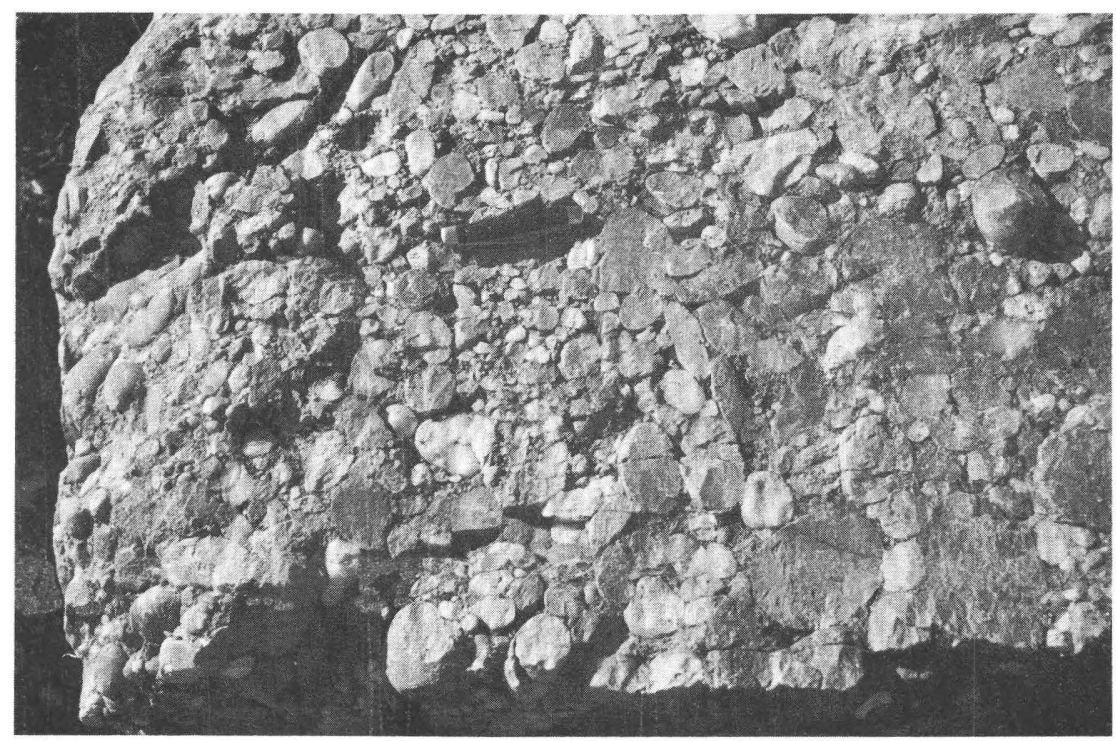

Figure 2.-Typical appearance of the Barnes Conglomerate Member of the Dripping Spring Quartzite. All pebbles and cobbles are well rounded. Only the most durable rock types-quartz and quartzite-survived the attrition that produced the conglomerate. This outcrop contains only a little matrix quartzite. Note that the fracture cuts the matrix and clasts indiscriminately.

In some places there is virtually no matrix, whereas in others the quartzite matrix exceeds the clasts and locally makes lenticular beds of quartzite as much as 2 feet thick. In several places near the base, beds occur in which the matrix is so rich in magnetite that the rock is black. Magnetite-rich beds also occur in the lower part of the quartzite unit of the Bolsa. In both occurrences, the magnetite is thought to be a primary terrigenous constituent.

\section{MIDDLE MEMBER}

The middle member of the Dripping Spring Quartzite is pink to dark red on weathered surfaces and a lighter pink to maroon on fresh fracture. Bedding is pronounced, and individual beds are from 2-4 feet thick. The quartzite, which is feldspathic, is medium grained and well sorted, in contrast to the Troy. Crossbedding is common, and abundant internal laminations mark all the beds. The feldspars weather out conspicuously. The middle member is 204 feet thick in Peppersauce Wash.

In a small isolated outcrop a few feet thick the middle member might be confused with the Bolsa Quartzite, but in general the middle 
member can be distinguished from the Bolsa by (1) better sorting, (2) more pronounced and thinner beds, (3) greater feldspar content, (4) absence of pebble beds and included pebbles in the quartzites, and (5) fine grain size.

The grain size of a typical specimen was estimated to range from 0.06 to $0.3 \mathrm{~mm}$ and to average between 0.10 and $0.15 \mathrm{~mm}$. The grains are rounded to subangular. Quartz constitutes 80-90 percent of the rock, and feldspar the remainder, except for minor amounts of chert, zircon, leucoxene, and iron oxide. The bulk of the feldspar is $\mathbf{K}$-feldspar; only a few grains of plagioclase were recognized.

The quartz grains are mostly clear single crystals, some of which have overgrowths. A few grains consist of a mosaic of interlocking crystals that had recrystallized before deposition. The source of these grains is presumed different from that of the single crystals.

The matrix, estimated to make up 10 percent of the rock, is a recrystallized aggregate of granular quartz and flaky sericite, virtually free of feldspar. The mild metamorphism indicated by recrystallization is the same as that indicated by the foliation in the Pioneer Formation. Possibly both resulted from the intrusion of the diabase; the metamorphism is pre-Paleozoic, and the diabase seems the most logical source of the heat and deformation necessary.

\section{UPPER MEMBER}

The upper member of the Dripping Spring ranges in color from rusty orange to tan and brown. It consists of quartzite beds ranging from $1 / 2$ to 18 inches in thickness and averaging about 2 inches, separated by shale partings as much as 4 inches thick, but generally less than half an inch. The shale partings weather easily, thereby emphasizing the quartzite beds and bedding. Most of the quartzite beds appear to be fine grained, well sorted, and internally laminated; some are crossbedded. Here and there are medium-grained feldspathic quartzite beds like those in the middle member, but they constitute only a minor part of the section. The member is 89 feet thick in Peppersauce Wash and nowhere appears to be thicker than 100 feet. Although the upper surface is an erosional one, the member crops out continuously throughout the extent of the formation.

The upper member differs from the middle because of (1) finer grain size, (2) thinner beds, (3) more slate partings, and (4) darker color. The contact between the two members is sharp, but there is no structural discordance and no indication of a break in sedimentation. 
The microscope reveals a range in grain size from that of silt to fine sand between beds and within some individual beds. Sorting is good, thus accounting for the distinctive bedding.

The quartzites consist of quartz, K-feldspar, sericite, and traces of other minerals. Quartz, the most abundant and prominent mineral, constitutes more than half of all but a few of the specimens studied. Sericite also occurs in all the rocks, and some beds are composed entirely of quartz, sericite, and a minor amount of iron oxide.

Some beds contain abundant $K$-feldspar (as much as 60 percent of the rock) associated with quartz and sericite. In several of these beds, the $\mathrm{K}$-feldspar is altered to sericite and presumably quartz. The alteration extends outward from centers, producing a spotted rock in which the spots are as much as 1 inch in diameter; where the spots coalesce, streaks are produced roughly parallel to the bedding. In addition, the disseminated iron oxide in the original rock was expelled during the recrystallization, and in some specimens the expelled iron collected as clots in the unaltered rock. This expulsion of the iron resulted in the distinct spots and streaks: the recrystallized iron-free areas are a dark gray, whereas the unaltered rock is a tan or light brown. It seems clear that quartz-sericite is the stable assemblage.

Plagioclase occurs only in a few scattered grains; it is not a significant constituent. In addition, a few grains of zircon, chert, and leucoxene were noted.

The following section of the Dripping Spring Quartzite was measured in Peppersauce Wash.

Stratigraphic section of the Dripping Spring Quartzite in Peppersauce Wash

Upper member : Quartzite, rusty orange, tan, and brown, thin-bedded, miFeet caceous. Internally laminated and crossbedded on small scale. Shale partings pronounced and characteristic. Quartzite beds range in thickness from $1 / 2$ to 18 in. but average about 2 in. Shale partings usually less than $1 / 2$ in. thick, but some as much as 4 in

Middle member: Quartzite, medium-grained, well-sorted, feldspathic; in beds $2-4 \mathrm{ft}$ thick. Crossbedded; internal laminations pronounced. Pink to dark red on weathered surface ; pinkish to maroon on fresh fracture.-

Barnes Conglomerate Member: Pebbles, cobbles, and boulders of wellrounded quartzite; lesser amounts of vein quartz and minor chert in a quartzite matrix. A 2-ft coarse-grained quartzite bed from 23-25 ft above base

\section{CAMBRIAN SYSTEM}

\section{BOLSA QUARTZITE}

In Stoyanow's description (1936) of the stratigraphic section in Peppersauce Canyon, the quartzite herein called Bolsa was correlated with the Troy Quartzite named by Ransome (1915) from exposures on 
Troy Mountain in the Ray district, which is about 20 miles north of the map area. Until recently the stratigraphic relation of the Bolsa and Troy Quartzites was uncertain, and many geologists thought the two were equivalent.

In the Holy Joe Peak quadrangle, which bounds the Mammoth on the north, Krieger (1961) found that the rocks heretofore called Troy contain a major unconformity separating Precambrian quartzite below from Cambrian quartzite above. The Precambrian quartzite is intruded by large stratiform masses of diabase, whereas the Cambrian quartzite rests on the eroded surface cut on the diabase and older quartzite. The U.S. Geological Survey now restricts Troy to the Precambrian quartzite and correlates the Cambrian quartzite with the Bolsa. In the Mammoth quadrangle, the quartzite unconformably overlies the stratiform diabase intrusives and locally contains Scolithus tubes, both of which indicate the quartzite is the Bolsa.

The Bolsa Quartzite of Middle Cambrian age was named by Ransome (1904) from exposures near Bisbee, Ariz., about 80 miles southeast of the map area. In the type area, it rests unconformably on Precambrian schists and is conformably overlain by the Abrigo Limestone.

The Bolsa Quartzite is chiefly in the southwest corner of the quadrangle south of the Mogul fault. In addition, a small patch of quartzite along the eastern edge of the quadrangle in secs. 28 and 33, T. 8 S., R. $18 \mathrm{E}$. is included with the Bolsa.

The Bolsa in the southwest corner of the quadrangle is broken and duplicated along the Mogul and subsidiary faults and is somewhat fragmented by the intrusion of the granodiorite porphyry. One stretch of continuous outcrop about 3 miles long ends against the granodiorite porphyry. Outcrops of Bolsa south of the granodiorite porphyry are in sec. 3, T. 11 S., R. 16 E., and extend southeastward from there.

The quartzite correlated with the Bolsa along the eastern edge of the quadrangle is an isolated exposure about 4,000 feet long and somewhat more than 1,000 feet wide. It is overlain by Tertiary volcanic rocks in the Galiuro Mountains, a short distance east of the quadrangle, and is overlapped on the west by the Gila Conglomerate. A reinterpretation of this isolated exposure may be necessary when the nature and distribution of the Paleozoic rocks in the Galiuro Mountains are known. Based on the rocks exposed in the Santa Catalina Mountains, however, these quartzites in the Galiuro Mountains most closely resemble the Bolsa, to which they are here assigned.

The Bolsa Quartzite disconformably overlies the upper member of the Dripping Spring Quartzite. Here and there the Bolsa was also deposited on the diabase, which is intrusive into the Dripping Spring. 
The Abrigo Formation conformably overlies the Bolsa; the contact is gradational over an estimated stratigraphic interval of about 30 feet, but it is arbitrarily placed where the massive cliff-forming quartzite changes to dark-brown thin-bedded quartzite separated by shale partings.

The Bolsa Quartzite is divided into a lower discontinuous maroon siltstone unit and an upper massive quartzite unit. In Peppersauce Wash, the siltstone is 93 feet thick, and in Nugget Canyon, where the siltstone is missing, the quartzite is 305 feet thick.

The maroon siltstone unit is a deep maroon and thinly laminated. It consists of subrounded to angular grains of quartz and plagioclase and flakes of sericite, set in a matrix of quartz and argillaceous material, very heavily impregnated with iron oxide. The dominant grain size in the thin sections studied was estimated at $0.03-0.05 \mathrm{~mm}$, well within the range for silt. The maximum grain size observed was 0.4 $\mathrm{mm}$; grains slightly smaller are common, however. Sorting actually is poor, but the poor sorting is not megascopically apparent because the average grain size is fine.

Quartz makes up about 90 percent of the grains. Plagioclase occurs sparsely, constituting only 1 or 2 percent. Sericite occurs as wellcrystallized flakes lying parallel to the bedding and perhaps as a finely divided constituent of the argillaceous matrix material.

The iron oxide-rich matrix material makes up 40-50 percent by estimate of the rock. The exact nature of the matrix was not determined because of the masking effect of the iron oxide. It does contain quartz and argillaceous material.

The maroon siltstone is completely free of $\mathbf{K}$-feldspar. This is in marked contrast both to the lower, thinner bedded part of the Bolsa in the areas where the maroon siltstone is absent and to the maroon slates in the Pioneer Formation.

Where exposed, the lower $11 / 2^{-2}$ feet of the maroon siltstone is a cobble or pebble conglomerate composed of fragments of jasper, diabase, and quartzite in a matrix of maroon siltstone, detritus from the diabase, and a mixture of the two.

It seems reasonable that the diabase in the upper part of the Dripping Spring Quartzite provided much of the material for the maroon siltstones. The heavy impregnation of iron and the absence of K-feldspar are compatible with such a source. Contamination by quartz grains would be expected from the abundant quartzite in the older rocks.

The quartzite unit of the Bolsa is generally white, but variations are common. Here and there it is stained pink or brownish from secondary iron and manganese, and the lower part of the quartzite unit character- 
istically consists of alternating black and white quartzite beds underlain by thin-bedded pink and white quartzites.

Beds range in thickness from a few inches to about 6 feet but average between 3 and 6 feet. The upper 200 feet of the formation locally forms prominent cliffs and is thicker bedded than the underlying section which consists of alternating zones of thick beds and of thin beds separated by shale partings. Grain size varies with bedding thickness; the thicker beds are coarser grained, and some of the coarsegrained beds are intercalated with thin lenticular pebble beds. The thin-bedded and fine-grained quartzites predominate in the lower part of the section, and where the maroon siltstone is missing, the Bolsa appears to grade into the upper member of the Dripping Spring Quartzite.

Sorting is poor, especially in contrast to the underlying Dripping Spring Quartzite and the overlying Abrigo Formation. Poor sorting, which precludes pronounced internal laminations, is one of the characteristics that helps to distinguish isolated outcrops of Bolsa from the middle member of the Dripping Spring Quartzite.

The following stratigraphic section is representative of the Bolsa where the maroon siltstone is absent.

Stratigraphic seation of the Bolsa Quartzite, Nugget Canyon

Three C Member of the Abrigo Formation :

Quartzite or sandstone, tan to dark-brown, thin-bedded, finely laminated, argillaceous.

Bolsa Quartzite :

3. Quartzite, white, massive, medium- to coarse-grained. Crossbedding common. Forms conspicuous cliffs. Beds range in thickness from 2 in. to $6 \mathrm{ft}$., but many are $4-6 \mathrm{ft}$. thick. Bedding planes marked by $1 / 4-1 / 2$ in. of micaceous fine-grained quartzite, commonly greenish from ärgillaceous impurities

2. Quartzite, chiefly black-and-white-layered, medium-grained. Forms cliffs separated by short slopes. Dark layers range in thickness from 2 in. to $2 \mathrm{ft}$., are rich in iron oxide minerals, and form (by estimate) 60 percent of rock

1. Quartzite, white, and pink, thin-bedded, medium-grained feldspathic. Beds range in thickness from 2 in. to $1 \frac{1}{2} \mathrm{ft}$., and are separated by green shale partings. Forms slopes, in contrast to overlying cliff-forming quartzites. A 2-ft. bed of coarse-grained quartzite about $10 \mathrm{ft}$. above base. Appears to grade into upper member of the Dripping Spring Quartzite

Total Bolsa Quartzite

Upper member of the Dripping Spring Quartzite :

Quartzite, tan, green, pink, and white, thin-bedded, fine-grained, thinly

laminated. Interbeds of shale or slate. 
In the area where the maroon siltstone is missing, the beds below the cliff-forming quartzites are of two types: massive beds like those in the overlying cliffs and thin-bedded quartzites separated by shale or slate partings. The former are composed of quartz grains and sericite flakes; they are virtually free of $\mathrm{K}$-feldspar. The latter consist of abundant quartz and $\mathrm{K}$-feldspar grains and sparse plagioclase grains and sericite flakes, all set in a matrix of sericite and other argillaceous material. In some of the thin-bedded quartzites, the matrix constitutes as little as 5 percent of the rock, so that most of the associated argillaceous material is in the shaly partings. The material in these thin-bedded quartzites and shales may have been supplied by erosion of the Dripping Spring Quartzite.

The black-and-white-layered rock, which is also below the cliffforming beds, consists of subrounded quartz grains set in a ferruginous matrix, probably derived from the diabase. The matrix, which compases about 25 percent of the rock, is so rich in iron oxide that other minerals besides quartz and sericite were not recognized.

The cliff-forming quartzites consist for the most part of an interlocking mosaic of quartz grains; matrix material is virtually absent. Quartz overgrowths on many of the grains are responsible for the tight interlocking of the grains and the consequent resistant nature of the beds. "Ghost" outlines indicate the grains were rounded to subrounded before precipitation of the overgrowths.

Feldspar is conspicuously absent in the upper part of the Bolsa. None was found in the specimens studied microscopically, and only a few scattered grains in a few beds were recognized megascopically during the field mapping.

\section{ABRIGO FORMATION}

The Abrigo Limestone of Middle and Late Cambrian age was named by F. L. Ransome (1904) from exposures on Mount Martin near Bisbee, Ariz., some 80 miles southeast of the map area. Subsequently, the name was used for the same stratigraphic interval in contiguous areas (Gilluly, 1956; Cooper, and Silver, 1964). Stoyanow (1936) correlated the Middle and Upper Cambrian rocks in Peppersauce Canyon in the Mammoth quadrangle with the type Abrigo, but adopted a new nomenclature. To replace the Abrigo Limestone, he proposed four new formations: Peppersauce Sandstone, Abrigo Formation, Southern Belle Quartzite, and Santa Catalina Formation, listed from youngest to oldest.

I have subdivided the Abrigo Formation into three members: from youngest to oldest they are the Peppersauce, Southern Belle, and Three $\mathrm{C}$ Members. The Peppersauce Member is equivalent to Stoyanow's 
Peppersauce Sandstone and Abrigo Formation, and the Southern Belle and Three C Members are equivalent to Stoyanow's Southern Belle Quartzite and Santa Catalina Formation, respectively. The Santa Catalina of Stoyanow, preempted for use as the Santa Catalina Gneiss of Blake (1908), is herein replaced by Three C.

The Peppersauce Member is named for Peppersauce Wash, the largest canyon in the quadrangle, and the one in which all the members of the Abrigo Formation are prominently exposed; the Southern Belle Member is named for the Southern Belle mine, which lies in unsurveyed sec. 20, T. 10 S., R. 16 E.; and the Three C Member is here named for the $3 \mathrm{C}$ Ranch, which is the largest ranch in the quadrangle. In Nugget Canyon, the Abrigo Formation is 735 feet thick, of which the Peppersauce Member comprises 335, the Southern Belle Member, 70 feet, and the Three C Member, 330 feet.

The Abrigo Formation crops out south of the Mogul fault in the southwest corner of the quadrangle. Except for minor offset and duplication by faults, it is exposed continuously southeastward for $2 \frac{1}{2}$ miles to where it is cut out for about a mile by the granodiorite porphyry. South of the porphyry, the Abrigo Formation crops out again and continues southeastward beyond the boundary of the quadrangle.

\section{THREE C MEMBER}

The Three C Member of the Abrigo Formation consists of reddishbrown thin-bedded largely fine-grained feldspathic sandstone, alternating with thin shale partings. Colors range from a slightly ironstreaked white, through pale reddish brown, to dark reddish brown; dark tones prevail. The member is characteristically thin bedded, beds averaging only 1 or 2 inches thick. Here and there, however, zones as much as 15 feet thick crop out strongly, and within these local cliff-forming zones, beds as much as 3 feet thick occur. Slate partings, which range in thickness from a film to an inch, characterize the thin-bedded parts of the member. Because of thin beds and shale partings, weathering produces thin sandstone slabs which cover the hill slopes. The bedding surfaces on these slabs are characteristic of the member; they are intricately irregular, the irregularities consisting of bumps, pits, ridges, valleys, all apparently intersecting in a haphazard manner. These bedding-plane irregularities reflect the internal bedding structures. Although the sandstone beds are finely laminated, reflecting good sorting, these fine laminations are interrupted every few inches by such internal structures as crossbedding, channels, discontinuous bedding, and by products of subaqueous slump, such as edgewise conglomerates (fig. 3 ). 


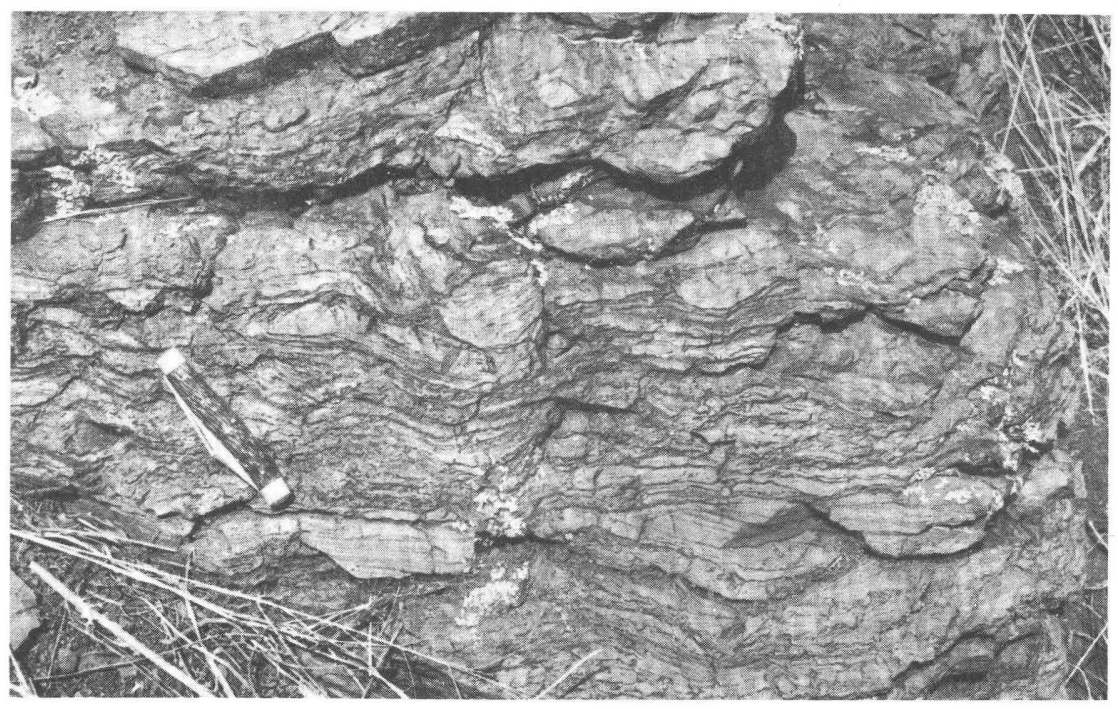

Figure 3.-Typical outcrop of the Three C Member of the Abrigo Formation. The fine laminations, crossbedding, and discontinuous sandstone beds are characteristic of this unit. This outcrop comprises both fine-grained sandstone and shale.

Thin dolomite beds, none of which exceed 6 inches in thickness, are sparsely distributed in the middle and upper parts of the member. These beds are all marked by discontinuous sandy masses, which weather out in relief. Some of these included masses are longest perpendicular to bedding, and they give the offhand impression of a breccia. Such masses, however, are thought to be due to irregularities in deposition.

The sandstone beds consist of abundant interlocking grains of quartz and K-feldspar. The matrix, which constitutes only a few percent of the rock, is sericite and minor amounts of feldspar and quartz. The quartz and $\mathrm{K}$-feldspar grains are subangular and are well sorted.

The shale partings consist of minor amounts of quartz and K-feldspar and abundant microcrystalline low-birefringent flakes and needles of sericite arranged in semiparallel orientation. The sericite needles bend around the more equant quartz and K-feldspar grains. Iron oxide in streaks and spots pervades all the slate and colors it red brown. An X-ray diffraction pattern of the slate has a strong sharp well-defined muscovite peak at $10.0 \mathrm{~A}$ and does not show any clay; therefore, I believe the clay minerals do not form a significant part of the shale. 
In contrast to the upper member of the Dripping Spring Quartzite, which is also a thin-bedded feldspathic unit, the $\mathbf{K}$-feldspar in the Three C Member is not altered to sericite.

The following stratigraphic section, measured in Nugget Canyon, is representative of the Three $\mathrm{C}$ Member of the Abrigo Formation.

\section{Stratigraphic section of the Three $C$ Member of the Abrigo Formation, Nugget Canyon}

Feet

Southern Belle Member of Abrigo Formation:

Quartzite, white, massive, thick-bedded. Cliff forming.

Three C Member of the Abrigo Formation:

13. Sandstone, brown, thin-bedded, slabby, fine-grained. Outcrops poorly

12. Sandstone, thin-bedded, limy. Weathered surface rough and pitted from solution of carbonate

10. Sandstone, brown, thin-bedded, fine-grained, slabby. Sh a le partings

9. Sandstone, light-tan, medium-grained, thick-bedded

8. Sandstone, brown, thin-bedded, fine-grained. Internal laminations. Shale partings

7. Sandstone, light-tan, medium-grained, crossbedded. Nonfeldspathic

6. Sandstone, brown, thin-bedded, slabby; separated by shale partings. Crossbedding, channels, and slump structures. Many beds finely laminated. Forms slope-

5. Sandstone, massive, fine-grained. Crops out prominently

4. Sandstones, brown, thin-bedded, fine-grained, slabby; separated by shale partings. Beds about 1 in. thick. Internal laminations common. Crossbedding, channels, and slump structure common. A few impure thin (3-in.) limestone beds. Forms slope

3. Covered on line of section. A few hundred feet off the section line, the unit is alternating fine-grained thin-bedded slabby argillaceous sandstones and thin silty shales. Sandstone predominates

2. Orthoquartzite, brown, coarse-grained. Bedding as much ás $3 \mathrm{ft}$ thick

1. Sandstone, dark-brown, thin-bedded, slabby; separated by shale partings

Total thickness

Bolsa Quartzite :

Quartzite, white, massive, cliff-forming.

\section{SOUTHERN BELLE MEMBER}

The Southern Belle Member is a white cliff-forming quartzite. It crops out in bold cliffs except where disrupted by the granodiorite porphyry, and even here semialined inclusions in the porphyry approximate its former trace.

236-465 $0-67-3$ 
The contact of the Southern Belle Member with the underlying Three C Member is somewhat arbitrary. Lithology typical of the Three C Member is separated from the white cliff-forming Southern Belle by a zone 15-20 feet thick that has characteristics of each of the members. This zone contains two or three tan coarse-grained crossbedded quartzites separated by thin-bedded slabby sandstone and shale typical of the Three C Member. In contrast, the upper contact, which is at the top of the cliff, is sharp.

The Southern Belle Member consists of well-sorted and well-rounded medium to coarse grains of quartz, almost all of which are overgrowths of quartz. The quartz overgrowths have filled all the original interstices, to form an interlocking aggregate in which all the contacts are sutured. This interlocking of quartz grains accounts for the extreme toughness of the rock and its consequent cliff-forming outcrops. Minerals other than quartz were not recognized; it is remarkably pure quartzite.

\section{PEPPERSAUCE MEMBER}

The Peppersauce Member of the Abrigo Formation comprises two distinct rock units: a lower thin-bedded unit and an overlying thicker bedded unit. The lower unit, which is about 200 feet thick, is light to dark-brown thin-bedded slabby fine-grained arenaceous dolomite and dolomitic sandstone. The upper unit, which is about 140 feet thick, consists of alternating beds of iron-stained coarse-grained crossbedded dolomitic sandstone and sandy dolomites.

The dolomitic sandstone beds contain varying amounts of iron oxide, and their color ranges from grayish red, through moderate brown, to dark yellowish brown. These beds alternate with arenaceous dolomites, which range in color from moderate yellowish brown to dark yellowish orange.

The contrast between the bedding in the upper and lower units of the Peppersauce Member is most striking. The average thickness of the beds in the lower unit cannot be more than 1 or 2 inches. Thin beds, many of which have fine internal laminations and structures, dominate every outcrop, and in the lower part of the unit, shale partings are conspicuous. Beds in the upper unit range in thickness from about 2 inches to perhaps 3 feet, and are estimated to average at least 1 foot. The difference in bedding between the lower and upper unit is so striking that the two could easily be mapped separately on this feature alone.

Both the lower and upper units are crossbedded, but on different scales. The crossbedding in the lower unit occurs in beds 1 or 2 inches thick, whereas in the upper unit it occurs in beds 1 foot or more thick. Some beds in the upper unit that are preponderately dolomite still 
exhibit excellent crossbedding. The sand grains are well distributed throughout these beds; such dolomitic beds are presumed to be entirely epiclastic (fig. 4).

The lower unit is noticeably finer grained than the upper unit. In the thin sections studied, the epiclastic quartz and K-feldspar grains in the lower unit average about $0.10 \mathrm{~mm}$ in diameter, whereas the diameter of the quartz grains in the upper unit averages about 0.40 $\mathrm{mm}$. The grain size of the dolomite is erratic in both the upper and lower unit; the dolomite in the upper unit, however, is appreciably coarser grained.

The relative distribution of the sandstone and dolomite in some beds of the lower unit is strikingly erratic. Locally, the sandstone

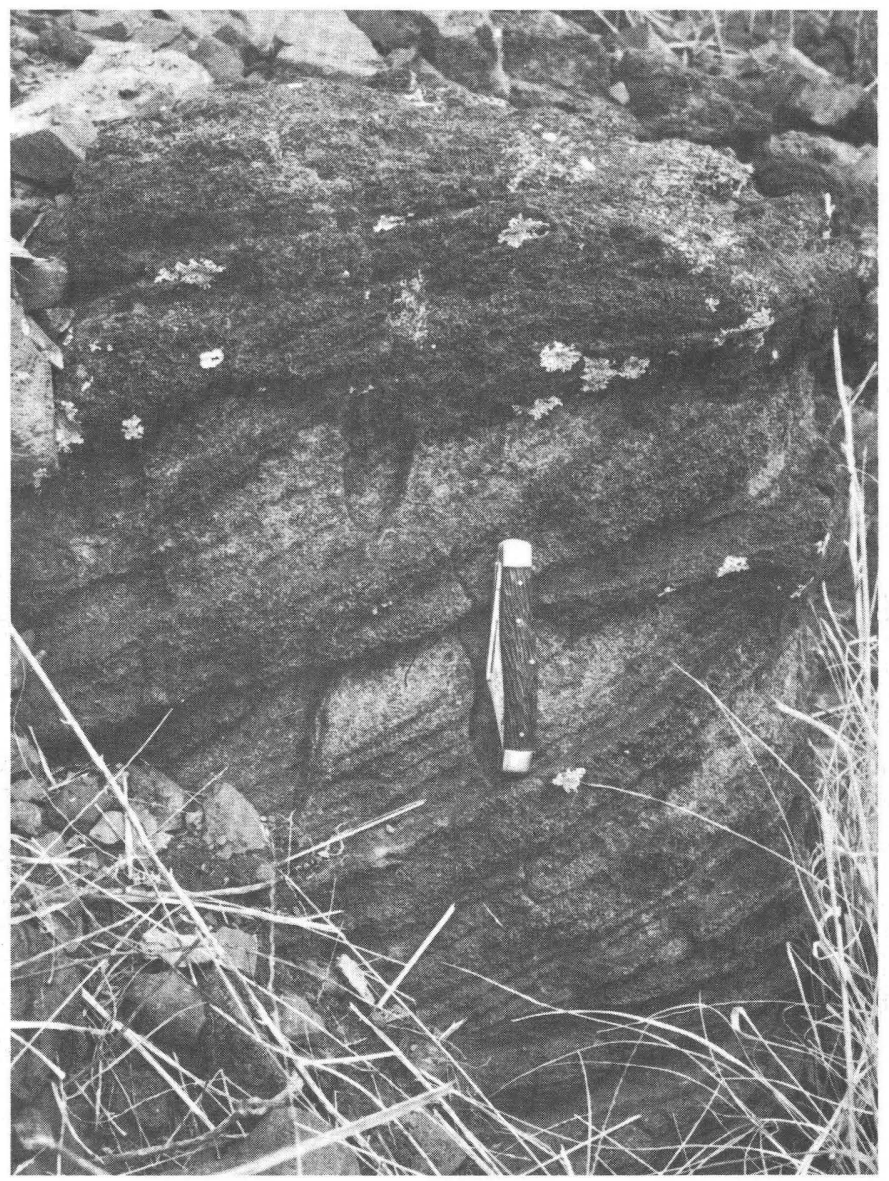

Figure 4.-Crossbedded sandy dolomite in the Peppersauce Member of the Abrigo Formation. The rock is dominantly dolomite, but it contains abundant rounded sand grains that mark the crossbedding. 
occurs in small chips entirely surrounded by dolomite, and in some beds these chips are randomly askew to bedding to form strange edgewise conglomerates (fig. 5.) In other beds the dolomite occurs in stubby lenses entirely surrounded by sandstone, producing discontinuous beds and uneven bedding surfaces similar to those in the Three C Member of the Abrigo Formation. In marked contrast with these erratic beds are outcrops of evenly bedded ribbon rock formed of alternating thin layers of sandstone and dolomite.

In the upper unit some beds contain sufficient iron or manganese oxide for weathering to form a black surface coating.

The section from Nugget Canyon (p. 33) is representative of the Peppersauce Member of the Abrigo Formation.

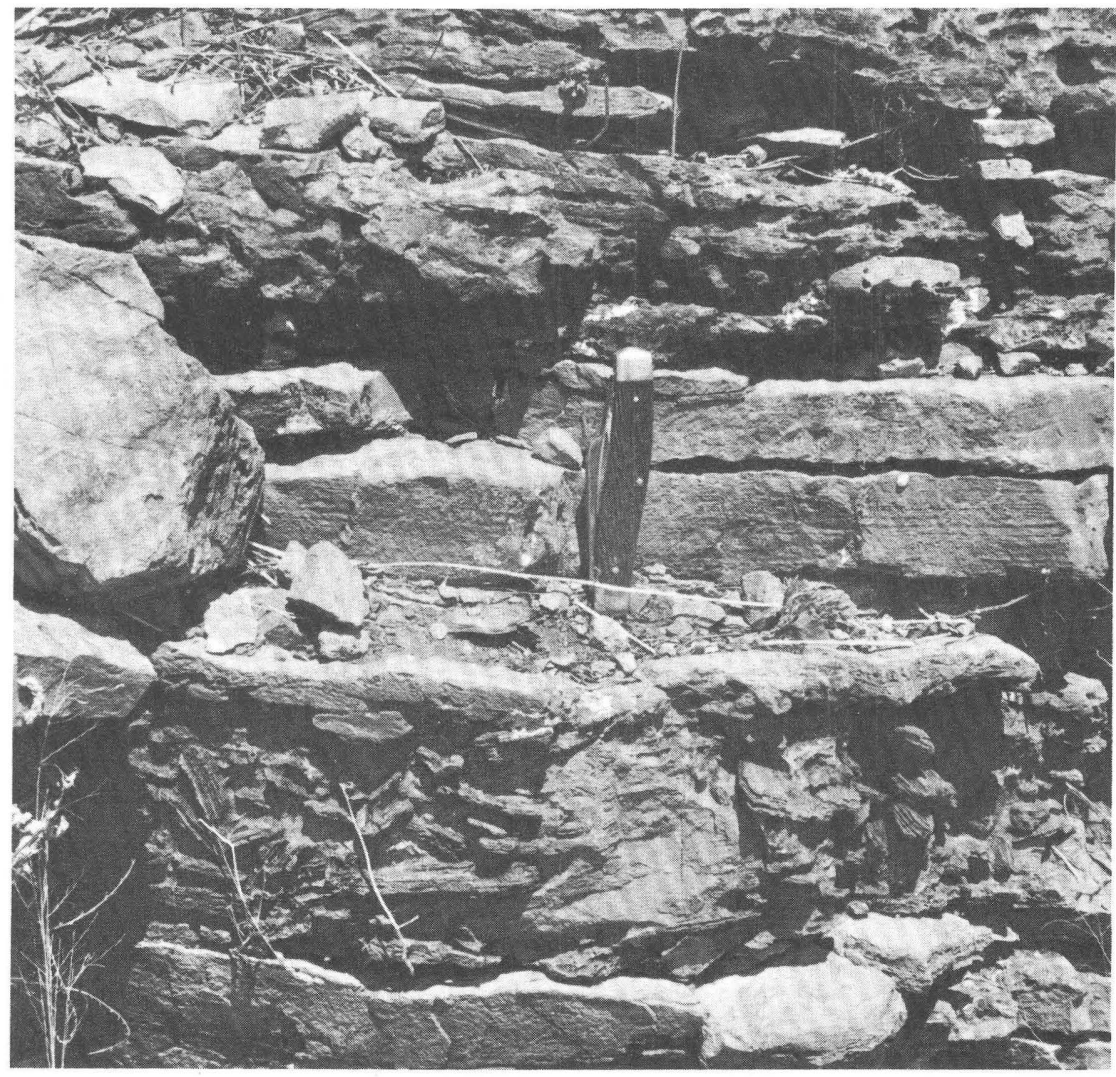

Figure 5.-Chip or edgewise conglomerate in the Peppersauce Member of the Abrigo Formation. In the 6-inch bed just below the knife, small sandstone chips occur embedded in dolomite. They stand out in strong relief because the dolomite weathers more rapidly. Chips lying with their long dimension at high angles to the bedding planes suggest that the conglomerate bed may have originated by submarine slumping. 
Stratigraphic section of the Peppersauce Member of the Abrigo Formation, Nugget Canyon

Martin Formation :

Feet

Limestone, medium-grained, blue-gray. Many colonial corals

Peppersauce Member of the Abrigo Formation :

7. Dolomite buff-colored, coarse-grained impure; in beds as much as $3 \mathrm{ft}$ thick. Subordinate amounts of interbedded dolomitic sandstone

6. Sandstone interbedded, coarse-grained, crossbedded; or quartzite and buff-colored coarse-grained dolomite

5. Dolomite, sandy and dolomitic sandstone; ribbon rock composed of alternating conspicuous layers. Individual layers range in thickness from 1 in to $1 \mathrm{ft}$

4. Sandstone medium- to coarse-grained, dolomitic; in beds 2 in to 3 ft thick. Crossbedded. "Subordinate interbeds of arenaceous dolomite

3. Sandstones, dolomitic and arenaceous dolomites; reddish-brown, fine-grained, thin-bedded, slabby. Becomes thicker bedded and slightly coarser grained toward top. Crossbedded._-_-_-_-_-_--

2. Dolomite conspicuous, arenaceous.-_-

1. Sandstones, dolomitic, and arenaceous dolomites; reddish-brown, fine-grained, thin-bedded, slabby. Crossbedded. Shale partings near base. Egdewise conglomerates and discontinuous beds locally prominent

Total thickness

Southern Belle Member of the Abrigo Formation :

Quartzite, white massive, thick-bedded, cliff-forming

The lower, thin-bedded unit (1-3, above) of the Peppersauce Member consists of abundant quartz, K-feldspar, and dolomite; sparse calcite; a trace of sericite; and enough iron oxide to give the rock a pervasive stain. The sandy beds are predominantly quartz and $\mathbf{K}$ feldspar, but dolomite always occurs as a subordinate constitutent. The carbonate beds are predominantly dolomite; some specimens contain a little calcite, but others do not. Both quartz and K-feldspar occur as impurities. The iron oxide, which is abundant, occurs as hematite.

The mineralogy of the upper unit (4-7, above) is similar to the lower, with one significant difference-it is free of $\mathrm{K}$-feldspar. In the lower unit, $\mathrm{K}$-feldspar constitutes as much as $30-40$ percent of some of the sandstone beds. The contrast with the upper unit, which is virtually free of even a trace of $\mathrm{K}$-feldspar, is most striking. In addition, magnetite occurs in the upper unit. It was not recognized in the lower unit, although oxidation might have vitiated its recognition.

\section{ALTERATION}

Along the north-central margin of the granodiorite porphyry, the Peppersauce Member was mildly altered by contact metamorphism. 
The metamorphism produced a uniform moderate-yellowish-brown color in both sandstone and dolomite beds, but mineralogic changes were slight; a little chlorite crystallized in irregularly shaped patches and in near-microscopic veinlets, associated with quartz, and calcite probably was produced. The increase of calcite in the contact zone, indicated by its greater abundance there, may have resulted from a reaction of dolomite + quartz + water $\rightarrow$ magnesian chlorite + calcite. This is supported both by the absence of dolomite in the larger chloritized patches, which suggests alteration of dolomite to chlorite, and by the very pale green color (colorless in thin section) of the chlorite, which suggests that it is magnesian.

\section{DEVONIAN SYSTEM}

\section{MARTIN FORMATION}

The Martin Limestone of Devonian age was named by Ransome (1904) for exposures on Mount Martin at Bisbee, Ariz. Subsequently, coeval rocks lying beneath the massive Mississippian limestones and extending from Prescott on the north to the international boundary on the south have been called Martin Limestone with few exceptions. Stoyanow (1936) described the Martin Limestone in Peppersauce Canyon. In addition to the Martin, he recognized a unit higher in the Devonian, which he determined to be the age equivalent (in part at least) of the Elbert Formation and the Ouray Limestone in Colorado. Stoyanow called these beds "Lower Ouray." There seems to be no lithologic basis for such a distinction; consequently, both of Stoyanow's units are included in what is herein called the Martin Formation of Middle Late Devonian age (Teichert and Schopf, 1958).

The Martin Formation occurs in the southwest corner of the quadrangle, south of the Mogul fault. It crops out from near the Mogal fault southeastward for about $2 \frac{1}{2}$ miles, where it is cut out by the granodiorite prophyry, and again southeast of the prophyry in secs. 2 and 3, T. 11 S., R. 16 E., continuing southeastward beyond the boundary of the quadrangle.

The Martin Formation disconformably overlies the Abrigo Formation and is disconformably overlain by the Escabrosa Limestone. The Abrigo Formation is of Middle and Late Cambrian age, and the Martin of Middle and Late Devonian age. The disconformity between the two, therefore, represents part of the Cambrian and Devonian Periods and all of the Ordovician and Silurian Periods. Although the Martin is Middle and Upper Devonian, it does not represent the latest Devonian; the Escabrosa is Lower and Upper Mississippian, but it may not represent the youngest Mississippian. 
Apparently, there is also a time break between the Martin and the Escabrosa, but not of the same magnitude as that between the Martin and the Abrigo. The geologic map of the Mammoth quadrangle, however, does not show any recognizable structural discordance between the Martin and either the underlying Abrigo or the overlying Escabrosa. In one outcrop on the north side of Nugget Canyon, the Martin appears to truncate a few thin beds of the underlying Abrigo, but exposures are too poor for the relations to be conclusive. In Nugget Canyon the Martin Formation is 252 feet thick.

The Martin Formation consists of thin-bedded dolomite, sandstone, and mixtures of the two. It is characteristically a grass-covered slope-forming formation lying just below prominent cliffs of Escabrosa Limestone.

The Martin in the Santa Catalina Mountains is medium grained and thin bedded. At no place are there coarsely crystalline beds like those in the overlying Escabrosa. Most beds are 1-2 feet thick. In the measured section only 2 or 3 carbonate beds as much as 3 feet thick are present, and one 6-foot sandstone bed is at the top of the section.

The carbonate beds are predominantly dolomite and contain only minor amounts of calcium carbonate. Effervescence with dilute hydrochloric acid suggests more calcium carbonate than was indicated by $\mathrm{X}$-ray diffraction. There is no doubt, however, that the section is preponderately dolomitic throughout.

The formation is readily divisible into three units: lower and upper dolomites separated by a middle sandstone and impure dolomite unit. The lower unit is characterized by alternating beds of blue-gray and tan dolomites. It contains one or two beds of limy sandstone low in the sections. The middle unit consists of pink and rusty-brown interbedded medium-grained sandstone or orthoquartzite and impure dolomite. The sandstone is well sorted and crossbedded. The impurities in the dolomite are chiefly clay. The color contrast with the overlying and underlying units is strong. The upper unit consists of tan dolomites capped by a 6 -foot orthoquartzite and sandstone bed, which consists of well-sorted sand grains whose average size is about $1 / 2^{-1 / 4}$ $\mathrm{mm}$. The grains are well rounded, but at least half have quartz overgrowths that have completely filled the interstices between grains. Grains not cemented by overgrowths are cemented with dolomite.

The upper unit is distinguished from the lower by the absence of the blue-gray dolomites and the presence of darker tan dolomites. In a formation that characteristically crops out poorly, the upper unit is most conspicuous. Commonly, individual dusky-yellow beds or groups of beds crop out for several hundred feet along the strike.

The following stratigraphic section is representative of the Martin Formation. 
Stratigraphic section of the Martin Formation in Nugget Canyon

Escabrosa Limestone :

Dolomite, massive, medium-bluish-gray, crystalline, thick-bedded.

Martin Formation :

Upper unit :

2. Sandstone and orthoquartzite, medium-grained, well-sorted. Light-brown to cream; white on fresh fracture. Dolomite and quartz cement. One bed, but distinctly laminated....--

1. Dolomite, medium- to fine-grained; in beds from $1 / 2$ to $3 \mathrm{ft}$ thick. Dusky yellow on weathered surface; olive gray on fresh fracture. Contains minor amounts of limestone

Middle unit :

2. Sandstone and orthoquartzite, moderate-red, massive, cliffforming; overlain by $10 \mathrm{ft}$ of poorly exposed bench-forming impure carbonate

1. Sandstone, moderate-red to pale-reddish-brown, mediumgrained, limy; alternates with moderate-red impure (argillaceous) dolomite; bedding from 1 to $2 \mathrm{ft}$ thick

Lower unit :

5. Limestone, blue-gray, medium-grained; in beds 1-2 ft thick. Massive bed $85-88 \mathrm{ft}$ above base of section. Fossiliferous_-

4. Carbonates, alternating beds of blue-gray and yellowish-gray, medium-grained; in beds 1-2 ft thick. Probably dominantly dolomite, but some beds are chiefly limestone. Some beds contain irregularly shaped masses rich in sand, which stand out in relief on weathered surfaces. Corals. Poorly exposed

3. Carbonate, light-tan, clastic

2. Sandstone, rusty-brown, medium-grained, limy. Beds about $1 \mathrm{ft}$ thick, and without internal laminations._.......-..--

1. Limestone, blue-gray, medium-grained. Bedding 1-2 ft thick. Corals___.

Total Martin Formation

Summary :

3. Dolomite, dusky-yellow; topped by 6 -ft orthoquartize and sandstone bed

2. Sandstones; moderate-red to pale-reddish-brown dolomitic, orthoquartzites alternating with moderate-red impure dolomites

1. Dolomites, alternating buff and blue-gray, medium-grained. Locally sandy

Peppersauce Member of the Abrigo Formation :

Dolomites, buff-colored, coarse-grained, impure; in beds as much as $3 \mathrm{ft}$ thick. Subordinate amounts of interbedded dolomitic sandstone. 


\section{MISSISSIPPIAN SYSTEM}

\section{ESCABROSA LIMESTONE}

The Escabrosa Limestone of Early and Late Mississippian age (Simons, 1964, p. 31) was named by Ransome (1904) for exposures on Escabrosa Ridge, near Bisbee. Such Mississippian limestones were deposited to a rather uniform thickness over much of the State (McKee, 1951). In the northern part of Arizona, these rocks are called the Redwall Limestone from exposures in the Grand Canyon of the Colorado, whereas in the southern part and extending at least as far northward as the Globe-Miami district, Escabrosa is the name used.

The Escabrosa Limestone crops out in the southwest corner of the Mammoth quadrangle south of the Mogul fault and in the isolated low hills in the southeast corner of the quadrangle, chiefly in sec. 19, T. 10 S., R. 18 E. South of the Mogul fault, it crops out in a discontinuous band near the $3 \mathrm{C}$ Ranch southeastward to the southern border of the quadrangle. The continuity is interrupted by overlap of Cretaceous and younger rocks and by intrusion of the granodiorite prophyry.

The outcrops of the Escabrosa Limestone, in contrast to those in the underlying Martin Formation, form bold cliffs from the middle and lower parts of the section, and where the cliffs are not present, the Escabrosa crops out prominently in unbroken slopes. These bold outcrops result from a crystalline carbonate lithology virtually free of interbeds of marl or shale. Prominent cliffs of Escabrosa occur on the north wall of Nugget Canyon and on the south wall of Stratton Canyon.

The section of Escabrosa Limestone in the Mammoth quadrangle probably is incomplete. It is overlapped unconformably by the Cretaceous(?) American Flag Formation and by the Pliocene and Pleistocene Gila Conglomerate. The most complete section is exposed on the north side of Nugget Canyon, and the section here may be complete, for the top 28 feet consist of medium- to thin-bedded sandy dolomites that lithologically are not typical of the Escabrosa. Only about 545 feet of Escabrosa is exposed in Nugget Canyon, however, and if this is complete, it is abnormally thin. According to McKee (1951, pl. 1), the Mammoth quadrangle lies in the area between the 600- and 700-foot isopachs for the Mississippian rocks, which in southeastern Arizona include only the Escabrosa Limestone.

The Escabrosa rests with apparent conformity on the Martin Formation of Middle and Late Devonian age. The two formations 
are separated by a 6 -foot orthoquartzite and sandstone bed. It is uncertain to which formation this bed belongs; it is included in the Martin, however, because of the abundance of sandstone beds and sand impurities in the Martin and the virtual absence of such impurities in the Escabrosa.

The color of the Escabrosa Limestone depends in part on composition: the limestone is light gray or very light yellowish gray on weathered surface and fresh fracture, whereas the dolomite is variable. Most of the dolomite tends to weather to a yellowish gray, but on fresh fractures it is medium gray or medium bluish gray.

The Escabrosa is characteristically massive and thick bedded, but the bedding characteristics vary from place to place in the section. In general, the limestone part is thicker bedded, and bedding planes are much less distinct than in the dolomitic part where color differences emphasize bedding. Dolomite beds $11 / 2-2$ feet thick are common, whereas limestone beds this thin are scarce. Internal laminations are conspicious in some dolomite beds but uncommon in the limestone beds. The contrasts in color, internal laminations, and bedding thickness between limestone and dolomite constitute the significant megascopic variations within the Escabrosa Limestone, which is noted for its lithologic uniformity.

Except for the uppermost 28 feet, the Escabrosa appears to be free of primary impurities. Secondary chert or jasper nodules are conspicuous in the upper part of the section and elsewhere are locally abundant.

The section of Escabrosa Limestone measured in Nugget Canyon contains limestone and dolomite: dolomite predominates in the lower 125 feet and from about 517 feet above the base to 545, where Cretaceous(?) rocks overlap the formation, and limestone predominates in the remainder. Some beds consist of a mixture of dolomite and calcite, but in most, either dolomite or calcite greatly predominates.

Grain size is closely related to composition. The dolomite is relatively even grained, and the average grain size is $0.1-0.2 \mathrm{~mm}$. In contrast, the grain size of the limestone is uneven, and consists of calcite crystals 1-2 mm in diameter, set in a fine-grained matrix whose average grain size is estimated to be about $0.01 \mathrm{~mm}$.

In thin section the rocks consist of an interlocking mosaic of carbonate grains. Locally, small equidimensional areas of microcrystalline quartz may be the start of the chert nodules; the source of the silica is not apparent in thin section.

The following stratigraphic section is representative of the Escabrosa Limestone. 
Stratigraphic section of the Escabrosa Limestone in Nugget Canyon

American Flag Formation :

Feet

Graywacke and siltstone, pale-olive to light-olive-gray, fine grained;

in beds $2-6$ in. thick

Escabrosa Limestone:

Dolomite, fine-grained, medium- to thin-bedded. Yellowish gray on weathered surface; medium gray on fresh fracture. Bedding $2-3 \mathrm{ft}$ thick by estimate. Some beds contain sparse disseminated sand grains

Carbonate, massive, gray and medium-dark-gray, coarsely crystalline ; chiefly limestone but contains dolomite. Surface rough and pitted; solution cavities. Bedding planes indistinct. Chert nodules sparse -_- -

Limestone, massive, yellowish-gray, coarsely crystalline. Thick bedded; bedding planes indistinct. Chert nodules abundant_-.--.-

Limestone and dolomite, massive, medium-gray, thick-bedded, crystalline. Distinct internal laminations

Dolomite, massive, fine-grained. Yellowish gray on weathered surface; medium bluish gray on fresh fracture. Beds average $1 \frac{1}{2}-2 \mathrm{ft}$ thick. Average grain size about $1 / 20 \mathrm{~mm}$. Sparse light-colored chert nodules

Dolomite, massive, medium-bluish-gray, crystalline, Thick-bedded. Average grain size about $1 / 10 \mathrm{~mm}$

Total Escabrosa Limestone

\section{Martin Formation :}

'Sandstone and orthoquartzite, medium-grained, well-sorted. One bed, but distinctly laminated

The Escabrosa Limestone contains two limestone caves, both of which seem to be well known to local speleologist. The largest of these is in the Nugget Canyon. The entrance, which is only about 2 by 2 feet, is about 100 yards upstream from where the Mount Lemmon road crosses Nugget Canyon on a stone bridge. The mouth of the cave is on the north wall about 30 feet above the floor of the canyon; a well-worn trail leads to the entrance.

The cave has been described and mapped by Priser (1948) (fig. 6). It is easily accessible and airy. Stalactites and stalagmites several feet long are common, but many are broken and otherwise marred.

The second cave is the SW:1/4, sec. 2 , T. 11 S., R. 16 E., on a small spur ridge where the attitude of the Escabrosa is indicated on the geologic map (pl. 1) as N. $50^{\circ} \mathrm{W} ., 30^{\circ} \mathrm{NE}$. The entrance is about 150 feet north of the fault; it is an irregularly shaped opening, about 15 feet wide by 25 feet long (from memory). Access is by a ladder and a steep incline. The cave consists of a magnificent central chamber and several smaller connected rooms. The cave openings, however, are not so extensive as those in Nugget Canyon. 


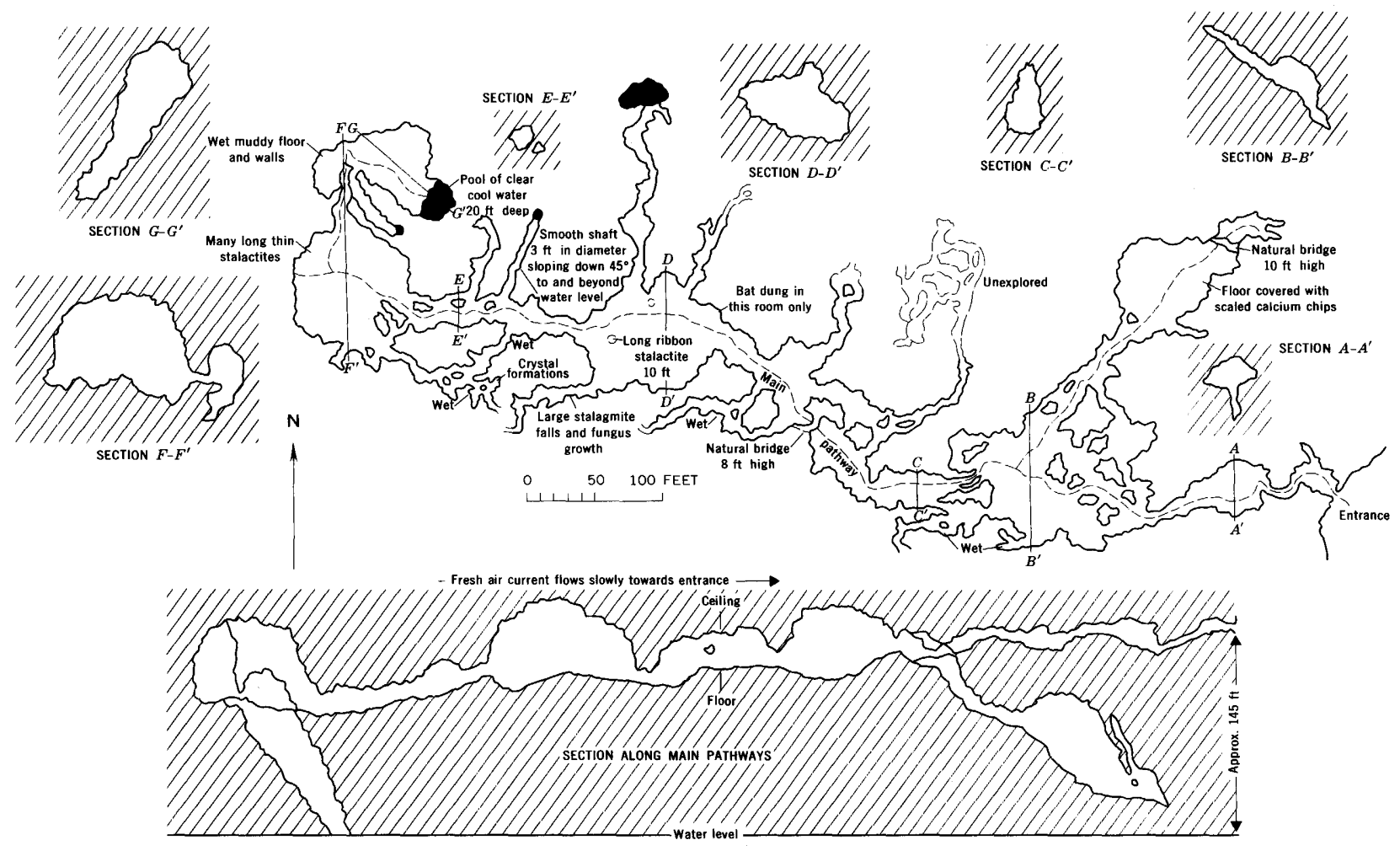

Figure 6.-Plan and sections of Peppersauce Cave, Nugget Canyon. The cave is cut from the Escabrosa Limestone. From Priser, 1948. 


\section{PENNSYLVANIAN AND PERMIAN SYSTEMS}

\section{NACO LIMESTONE}

The Naco Limestone of Pennsylvanian and Permian age was named by Ransome (1904) from exposures in the Naco Hills in the Bisbee district. Subsequent workers, such as Gilluly (1956), have subdivided the formation and raised the Naco to group status. The short stratigraphic interval and isolated outcrops of the Naco in the Mammoth quadrangle make an assignment to a subdivision uncertain and therefore undesirable.

A small patch of Naco Limestone only a few acres in surface area crops out on the east side of a low group of hills (inappropriately called the Black Hills) in the southeast corner of the quadrangle. The exposure is bounded by the Escabrosa Limestone on the west and the Gila Conglomerate on the east. About 100 feet (by estimate) of the formation is exposed.

The Naco Limestone is light to medium gray. A few beds have a pinkish cast owing to impurities. The breviated section consists of interbedded limestone, in beds 1-2 feet thick, and marls. The limestone crops out prominently; the marl does not.

\section{CRETACEOUS (?) SYSTEM}

\section{AMERICAN FLAG FORMATION}

The American Flag Formation occurs in the southwest corner of the quadrangle south of the Mogul fault. It is herein named for the American Flag spring, which is a well-known landmark in the area. Several isolated patches of the formation lie to the east of the Paleozoic rocks and west of the Gilo Conglomerate, and undoubtedly are continuous beneath the cover of Gila. The largest outcrop area is between Peppersauce and Nugget Canyons. To the south in the quadrangle, the American Flag Formation crops out only in two small areas on the walls of Stratton Canyon.

The formation does not crop out strongly. The best exposures are along the Mount Lemmon road and in Nugget Canyon where the type section was measured.

The age of the American Flag Formation is Cretaceous(?). The formation unconformably overlies the Escabrosa Limestone and is unconformably overlain by the Gila Conglomerate. It is intruded by the granodiorite porphyry whose Cretaceous(?) age is based on lithologic correlation with the Cretaceous(?) granodiorite porphyry in the San Manuel deposit (p. 47). Bromfield (1950) found the fresh- 
water pelecypod Unio and the gastropod Viviparus in green mudstone from near the base of the formation on the ridge north of Nugget Canyon. Unio has a time range from Triassic to Recent. Viviparus has a known range from Cretaceous to Recent and a possible range that includes the Permian and Triassic. The Paleozoic section in southeastern Arizona, which is well known, contains no rocks remotely similar to the American Flag Formation, and Triassic and Jurassic sedimentary rocks are missing from southeastern Arizona. It seems likely, therefore, that the American Flag Formation is Cretaceous(?).

The American Flag Formation weathers to various shades of olive brown and produces a dark-brown soil. On fresh fracture, however, the rocks are light olive gray or greenish gray. The formation is well bedded, and bedding ranges in thickness from a few inches to 10 or 20 feet. Some of the fine-grained graywackes are finely laminated, and a few contain slump structures. Crossbedding and cut-and-fill features occur in some of the coarse-grained graywacke beds.

In Nugget Canyon near the fault at the base of the section, the coarser grained graywackes are cut by conspicuous joints and the siltstones and finer grained graywackes by a rock cleavage. The joints and cleavage strike northwest approximately parallel to the strike of the beds, but they dip westward at $20^{\circ}-45^{\circ}$; this attitude is like that of the crude foliation in the granodiorite porphyry lying to the west.

In the exposure of the American Flag Formation between Peppersauce and Nugget Canyons, fine- to medium-grained graywackes characterize the lower part of the section, and conglomerates the upper part. The lower rocks are particularly well bedded. At about 200 feet above the base, a 30-foot limestone conglomerate occurs, and this is approximately where the conglomerate beds become conspicuous. Higher in the section the conglomerates increase in abundance, alternating with graywacke beds. As the conglomerates increase, the finegrained graywackes or siltstones decrease, and the interbeds are largely medium- to coarse-grained graywacke. Higher in the section the conglomerate beds become thicker, reaching a maximum of 10-20 feet, and the relative abundance of conglomerate increases until it is the predominant rock type. The relative abundance of the different rock species among the boulders and cobbles also changes: the pebbles and cobbles in the lower conglomerate beds, which are well exposed along the Mount Lemmon road, are largely volcanic. Higher in the section, the volcanic cobbles gradually give way to abundant quartzite clasts and sparse limestone, gneiss, and granitic clasts. The matrix material and interbeds, however, remain graywackes. This pattern extends to the overlap of the Gila Conglomerate. 
The patch of American Flag Formation north of Peppersauce Wash has lithologic types not recognized to the south. At the base of the formation, which here rests on the Escabrosa Limestone, it is a sedimentary breccia as much as 50 feet thick, derived from the adjacent Paleozoic rocks. The breccia is largely a poorly sorted rubble of angular blocks; however, a few individual beds exhibit good sorting. The poor sorting, angular character of the fragments, and the abundance of fragments like the adjoining bedrock all indicate short transport from a local source. The absence of the zone to the south is probably due to nondeposition.

A zone of maroon fine-to medium-grained clastic rocks several hundred feet wide crops out in the same area. A bedded sedimentary breccia, about 700 feet in outcrop width and composed almost exclusively of angular fragments of granitic rock, overlies the maroon rocks. Neither of these two rock types occurs elsewhere in the map area.

Another rock type that may be part of this formation occurs in the roadcuts of the Mount Lemmon road on the east wall of Stratton Canyon where it crosses the southern boundary of the quadrangle. Here a small patch of andesite (?) is surrounded by Gila Conglomerate. The exposures are such that $I$ am uncertain whether the andesite is interbedded in the Gila or is an outcrop of a larger mass of the American Flag Formation beneath the Gila.

The graywacke part of the formation consists of angular to subangular sand- and grit-sized grains of quartz (abundant), chert (abundant), and feldspar (sparse) and of small rock fragments, all set in a silty matrix composed of comminuted rock in which chlorite, sericite, carbonate, iron oxide, and possibly clay can be resolved with a petrographic microscope. The relative proportions of grains and matrix varies from bed to bed. Obviously the coarser grained beds are richer in the grains, and the laminated siltstones are virtually all matrix material.

The small rock fragments are altered. In several thin sections they consist of abundant sericite and felsic material, either quartz, feldspar, or both. In one section they consist of aggregates of chlorite and carbonate. The average size of the sericitized fragments is at least double the average size of the grains with which they are associated. This suggests that the fragments were less dense than the grains; they may have been pumice.

The following section from Nugget Canyon is representative. 
Stratigraphic section of the American Flag Formation in Nugget Canyon

Gila Conglomerate :

Poorly sorted boulder conglomerate.

Unconformity.

American Flag Formation :

13. Conglomerate, massive, thick-bedded; contains boulders as much at $3 \mathrm{ft}$ in diameter. Boulder derived from quartzites (at least 3 types), gneiss, quartz porphyry, quartz monzonite (Oracle Granite), diabase, and limestone. A few interbeds of coarsegrained graywacke.

12. Largely covered. The sparse outcrops are conglomerate, probably similar to unit 13

11. Like unit 13, but interbeds of coarse-grained graywacke are slightly more abundant.

10. Largely covered. Few outcrops, similar to unit 13

9. Conglomerate and massive greenish-gray graywacke, interbedded. Bedding ranges in thickness from $1 / 2$ to $10 \mathrm{ft}$. Pebbles and cobbles derived from quartzite (most abundant), granitic rocks, diabase, and limestone. Contact below is gradational.......--

8. Conglomerate, massive, thick-bedded; contains boulders, as much as $3 \mathrm{ft}$ in diameter, of quartzite, gneiss, quartz porphyry, quartz monzonite (Oracle Granite of Peterson), diabase, and limestone, all set in a matrix of graywacke

7. Graywacke and conglomerate, intercalated, greenish-gray fineto medium-grained. Cobbles and boulders in conglomerate derived largely from volcanc rocks but some from quartzite....-

6. Conglomerate, thick-bedded, massive; contains quartzite boulders as much as 6 in. in diameter. Graywacke matrix

5. Graywacke and cherty graywacke, pale-olive, finely laminated, scattered outcrops; interbedded here and there with 1-ft conglomerate beds composed of pebbles and cobbles of volcanic rock of intermediate composition

4. Mostly covered. Intermittent outcrops of pale-olive finely laminated graywacke and cherty graywacke. Very light gray to light greenish gray on weathered surface; greenish gray to dark greenish gray on fresh fracture

3. Conglomerate, limestone; contains cobbles of white and black chert

2. Graywackes, pale-olive to greenish-gray, fine- to medium-grained; a few 1-ft discontinuous conglomerate beds containing quartz pebbles. Medium-grained graywacke very abundant. Beds

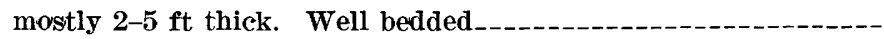

1. Graywacke and siltstone, pale-olive to light-olive gray, finegrained; in beds $2-6$ in. thick. Slump structures in the siltstone. Jointing pronounced. About $45 \mathrm{ft}$ above base, brecciated rock indicates a possible fault, and the base of the formation is bounded by a fault of small stratigraphic throw

Total

Escabrosa Limestone :

Carbonate, massive, gray and medium-gray, coarsely crystalline; chiefly limestone but contains carbonate. 


\section{GRANODIORITE PORPHYRY}

The granodiorite porphyry occurs in two general areas: one in the southwest corner of the quadrangle and the other in a poorly defined zone that trends southwestward from near the abandoned town of Tiger to a point about midway along the western boundary of the quadrangle. This zone includes the San Manuel ore deposit, which is also elongated southwestward.

The largest mass of granodiorite porphyry occurs in the southwest corner of the quadrangle south of the Mogul fault. Although irregular in shape, it covers about 4 square miles. Within the southwestward-trending zone, dikes and irregularly shaped masses occur in the bedrock area bounded by the Mammoth, San Manuel, and Turtle faults. These or related masses extend to the southwest beneath the Gila Conglomerate, as shown by the subsurface openings in the San Manuel mine. Similarly, dikes and irregularly shaped masses of porphyry crop out in the inlier of older rocks surrounded by Gila Conglomerate roughly 2 miles southwest of the San Manuel deposits.

Smaller exposures include an unusual interconnected set of porphyry dikes which crop out in secs. 19 and 20, T. 9 S., R. 16 E., and finally, small irregularly shaped masses are in the bedrock horst between the Mammoth and San Manuel faults in sec. 1, T. 9 S., R. 16 E.

The granodiorite porphyry is a gray rock whose color index ranges from 10 to 20 , and probably averages near 13 . The disseminated mafic constituents in the microcrystalline groundmass darken the rock more than what would be expected from the normative or chemical composition.

The granodiorite porphry is altered in all outcrops, but the texture is well preserved and sufficient mineral relicts remain, so that the original nature of the rock is easily established. The rock is holocrystalline porphyritic with an aphanitic groundmass. It consisted originally of phenocrysts of plagioclase, biotite, and hornblende in a microgranular groundmass. The groundmass comprised plagioclase laths or microlites, granular quartz, K-feldspar, and mafic constituents. In a few specimens the groundmass texture tends toward pilotaxitic, owing to abundant plagioclase microlites. Accessory minerals, which are all primary, consist of apatite, magnetite, zircon, and rutile; apatite is the most abundant. 
The composition of the phenocrystic plagioclase now ranges from $A n_{0-5}$ to $A n_{55}$. The wide range in composition is due to a pervasive alteration which albitized the plagioclase; presumably $\mathrm{An}_{55}$ approximates the primary composition. Although some phenocrysts are zoned, the range in composition was not determined. Common alteration assemblages of the plagioclase are albite-kaolinite-calcite, sericitecalcite, and sericite-calcite-epidote (or some other member of the epidote group). Calcite is much more common in the porphyry near the San Manuel ore deposit, whereas both calcite and epidote group minerals are common in the porphyry mass in the southwest corner of the quadrangle.

Some of the specimens of granodiorite porphyry originally contained both biotite and hornblende; the others contained only biotite. In the central part of the quadrangle, the most common alteration assemblage of biotite and hornblende is chlorite-carbonate (mostly calcite)-muscovite. Leucoxene or granular rutile is an alteration product due to release of titanium from biotite. Biotite altered first to a light-greenish biotite; more intense alteration produced chlorite, calcite (or other carbonate), muscovite, epidote, leucoxene, magnetite, and iron oxide. Here hornblende altered to chlorite, carbonate, muscovite, epidote, magnetite, and iron oxide. Hornblende was more susceptible, to alteration than biotite; in some specimens where hornblende was completely altered to pseudomorphs of secondary minerals, biotite, although strongly altered, still remained.

The porphyry in the southwestern part of the quadrangle contains minor amounts of residual biotite and hornblende and rare pseudomorphs after these minerals. The products from the alteration of the biotite and hornblende are abundant chlorite, carbonate, and epidote; in addition, muscovite (sericite), granular rutile or leucoxene, and magnetite are common. In some sections the magnetite is concentrated as small grains around the periphery of the altered mineral; iron, apparently expelled during alteration, crystallized as magnetite at the edge of the altering crystal. Although carbonate and epidote locally are associated as joint alteration products of mafic minerals, generally only one or the other occur.

Because all the granodiorite is altered, analyses truly representative of the fresh porphyry are not possible. The following analyses, however, are from the freshest porphyry available.

The relation of the porphyry to other rocks and lead-alpha age 


\section{Chemical analyses and norms of granodiorite porphyry}

[Specimen data: (1) Granodiorite porphyry from central part of sec. 4, T. 9 S.. R. 16 E. Rapid analyses by P. L. D. Elmore, K. E. White, and S. D. Botts; (2) granodiorite porphyry from a point 7,500 ft N. $48^{\circ}$ E. of Rice Peak, which is in the southwest corner of the Mammoth 15-minute quadrangle. Rapid analyses by P. L. D. Elmore, S. R. Barlow, S. D. Botts, and G. Chloe]

\begin{tabular}{|c|c|c|c|c|c|}
\hline \multicolumn{3}{|c|}{ Chemical analyses (weight percent) } & \multicolumn{3}{|c|}{ Norms (weight percent) } \\
\hline & 1 & 2 & & 1 & 2 \\
\hline 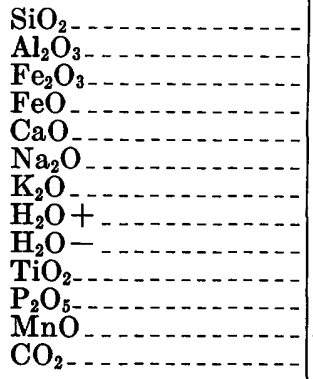 & $\begin{array}{r}61.8 \\
16.5 \\
3.3 \\
1.2 \\
2.6 \\
4.3 \\
2.5 \\
1.9 \\
.5 \\
.62 \\
.22 \\
1.0\end{array}$ & $\begin{array}{r}61.8 \\
16.8 \\
3.0 \\
2.6 \\
5.0 \\
3.8 \\
1.9 \\
2.0 \\
.70 \\
.26 \\
.11 \\
.15\end{array}$ & 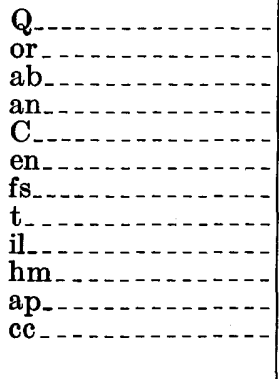 & \begin{tabular}{l}
19.0 \\
15.0 \\
36.1 \\
10.6 \\
2.86 \\
6.5 \\
\hdashline 2.1 \\
1.22 \\
1.92 \\
.34 \\
2.23
\end{tabular} & $\begin{array}{l}20.0 \\
11.1 \\
32.0 \\
21.4 \\
.71 \\
4.7 \\
1.1 \\
4.41 \\
1.37 \\
.7 \\
.5\end{array}$ \\
\hline
\end{tabular}

determination on zircons indicate that the porphyry is probably Cretaceous, but it may be early Tertiary. The porphyry is older than the Cloudburst Formation of Cretaceous or Tertiary age. Fragments of mineralized porphyry that could have come only from the San Manuel deposit occur in the Cloudburst Formation lying between the Mammoth and San Manuel faults in sec. 36, T. 8 S., R. 16 E. Volcanic fragmental rocks (Ross, 1925) that can be correlated with the Cloudburst Formation occur east of Winkelman about 20 miles north-northeast of the Mammoth quadrangle. These fragmental volcanic rocks (Ross, 1925) unconformably overlie Upper Cretaceous sandstones and shales of Colorado age. If the correlation is correct, the Cloudburst Formation is Late Cretaceous or younger.

The porphyry south of the Mogul fault intruded Paleozoic rocks and the American Flag Formation from which Bromfield (1950) reported the fresh-water pelecypod Unio and the gastropod Viviparus. Unio has a time range from Triassic to Recent, and the most probable range of Viviparus is from Cretaceous to Recent.

Zircons were extracted from a sample of porphyry collected near the $3 \mathrm{~A}$ and $3 \mathrm{~B}$ shafts on the 1475 haulage level of the San Manuel mine. The age of these zircons by the lead-alpha method was determined to be 97-130 million years by H. W. Jaffe, of the U.S. Geological Survey. 


\section{CRETACEOUS(?) AND TERTIARY(?) SYSTEMS}

\section{GLORY HOLE VOLCANICS}

The Glory Hole Volcanics were named by Simons (1964) after the Glory Hole (or Globe) mine near the south edge of sec. 3, T. 8 S., R., $18 \mathrm{E}$., in the southwest corner of the Klondyke quadrangle. In the Mammoth quadrangle, they occur in the northeast corner in two small masses, whose combined area is less than 1 square mile. These masses are the southwestern extension of a larger mass along Copper Creek, chiefly in the Klondyke quadrangle to the northeast.

The Glory Hole Volcanics are unconformably overlain by the Tertiary Galiuro Volcanics, although the unconformity is not readily seen in the Mammoth quadrangle. The contact between the two, however, is obviously discordant to the gently $\left(10^{\circ}\right)$ eastward-dipping pyroclastic beds in the upper part of the Galiuro Volcanics east of the quadrangle. Simons (1964), who studied the rocks east of the quadrangle, points out that the Copper Creek granodiorite intrudes the Glory Hole Volcanics and both are disconformably overlain by the Galiuro Volcanics. Thus, the time interval between the accumulation of the Glory Hole and the Galiuro Volcanics was sufficiently long to allow intrusion, solidification, and unroofing of the granodiorite, which is a medium-grained equigranular rock. The cover over the granodiorite must have been in excess of 1,000 feet.

Only a partial section of Glory Hole Volcanics crops out within the quadrangle, and no attempt was made to measure the thickness. Simons (1964) reports the Glory Hole Volcanics in the southwest corner of the Klondyke quadrangle to be about 1,500 feet thick; this also is only a partial section because the base is not exposed.

The Glory Hole Volcanics are a mixed sequence of tuffs, welded tuffs, breccias, lavas, and flow breccias (Simons, 1964). Within the Mammoth quadrangle, the Glory Hole appears to be chiefly lavas and perhaps some flow breccia; in contrast, the southern exposure consists of lithic tuffs and volcanic breccias.

The northern outcrops are a massive dark-greenish-gray rock in which the visible constituents are limited to sparse plagioclase phenocrysts, intensely altered mafic material, and secondary epidote set in a greenish-gray aphanitic matrix. Thin sections show the rock to be holocrystalline porphyritic with a microgranular groundmass. The rock originally consisted of phenocrysts of plagioclase and a mafic mineral set in a groundmass largely of plagioclase. Now the phenocrystic plagioclase is partly altered to epidote and indeterminant finegrained alteration products. The original mafic mineral is represented by iron ores, by aggregates of green hornblende, by a little clear $\mathrm{K}$-feldspar, and probably by epidote. The groundmass also contains 
alteration products; epidote was the only one I recognized, but another mineral too fine grained to be resolved with a petrographic microscope is also present.

The southern mass by contrast is clearly a pyroclastic rock composed of gray to purple fragments of andesite set in a tuffaceous matrix. Sorting is evident in two sequences, several feet thick, that grade from a basal breccia in which individual blocks are as much as 18 inches in diameter to upper beds in which the largest fragments are about 3 inches. The clasts are angular, and although all are andesitic or latitic in composition, several textural varieties occur. The clasts make up roughly half the rock.

The matrix is light gray, cream, or white. It probably was tuffaceous, but it has recrystallized to fine-grained equigranular aggregate of feldspar and quartz.

Both masses are similarly altered. Epidote is the most conspicuous secondary mineral, but other fine-grained alteration products occur. The fragments and groundmass are altered indiscriminately.

The Glory Hole Volcanics are intruded in the Klondyke quadrangle by the Copper Creek Granodiorite, whose isotopic age by the K-Ar method on biotite is 69 million years (corrected value, Creasey and Kistler, 1962) and on hornblende is 66 million years. They are overlain unconformably by the Galiuro Volcanics, which may be of middle Tertiary age, according to Simons (1964). Although the age of the Glory Hole Volcanics cannot be determined more precisely by geologic relations, Simons (1964) thinks that the most likely age is Late Cretaceous to earliest Tertiary.

\section{CLOUDBURST FORMATION}

Cloudburst is a name first used during the geologic studies that followed discovery of the San Manuel deposit. The first reference to it is a very brief description by E. D. Wilson in May 1957, in a paper describing the fracture pattern associated with the San Manuel deposit. Two months later, Pelletier (1957) published a short account of the geology of the San Manuel deposit in which he devoted a short paragraph to the distribution of the Cloudburst Formation near the ore body. Heindl (1963) adds to the description of the formation, but neither describes it in detail nor designates a type or reference section. Creasey (1965) presents a general description of the lithology and designates Cloudburst Wash in the Mammoth quadrangle as the type locality. Unfortunately, Cloudburst Wash is unnamed on the topographic map.

The Cloudburst Formation crops out in the northwest corner of the quadrangle, in the bedrock horst bounded by the San Manuel and 
Mammoth faults southeast of the San Manuel mine, and in four dikes that cut the quartz monzonite in Cottonwood and Smelter Washes.

The formation includes three lithologic types: (1) fanglomerate, (2) a distinctive monolithologic sedimentary breccia, and (3) volcanic rocks comprising intercalated latite flows, flow breccias, and minor intrusive equivalents of the latite. These lithologic types are not considered members because they lack persistent stratigraphic relations to each other. Rather, they are the major rock types in the Cloudburst Formation.

The exposed thickness of the Cloudburst Formation along a N. 35 E. line in sec. 22 , T. 8 S., R. 16 E., is about 6,000 feet, including both fanglomerates and lavas, but neither the top nor the bottom of the section is exposed. The thickness of the fanglomerates south of the San Manuel fault, calculated from an east-west section about 1,000 feet south of the northern boundaries of secs. 32 and 33, T. 8 S., R. $16 \mathrm{E}$., is about 4,800 feet, and the lavas lying to the west within the area are about 2,000 feet thick including a bed of fanglomerate about 100 feet thick. Here also, neither the top nor the bottom of the section is exposed.

The lithology of the fanglomerate in the Cloudburst Formation changes from one series of beds to another and along the strike, but it could not be determined whether these changes were due to lenticularity of the beds of different compositions or to variation of rock types within a single bed, or to both.

Fragments range in size from $1 / 16$ inch to 10 feet; boulders 10 feet in diameter are rare, but those 5 feet in diameter are common. Sorting ranges from poor to good: the volcanic sandstones are well sorted; the fanglomerates are not. Bedding is best shown by beds whose fragments are less than 1 foot in diameter. Induration is moderate, in marked contrast to the adjacent Gila Conglomerate.

Fragments in the fanglomerate include quartz monzonite (Oracle Granite of Peterson, 1938), granodiorite, mafic volcanic rocks, diabase, aplite, hornblende-biotite andesite, rhyolite, granodiorite porphyry, quartzite, limestone, and gabbro. Of these, the granitic and mafic volcanic rocks are estimated to make up at least 85 percent of the fragments. The source of the limestones and quartzites could be the Paleozoic rocks and the Apache Group, exposed in the Santa Catalina Mountains. Presumably, the gabbro is a phase of the diabase that is abundant in the Santa Catalina and Galiuro Mountains. Possible sources for the hornblende-biotite andesite and the rhyolite are not known.

The fanglomerate from the central part of sec. 27 , T. 8 S., R. 16 E., extending northeastward into sec. 26 on both sides of Tucson Wash, consists chiefly of fragments derived from the lavas in the Cloudburst 
Formation. A few beds contain fragments of other rocks, chiefly quartz monzonite; but rhyodacite, quartzite, and possibly aplite are also present.

The fanglomerates in Cloudburst Wash (secs. 28 and 29, T. 8 S., R. 16 E.) west of the San Manuel fault consist predominantly of crudely bedded brick-red fanglomerates derived almost wholly from the quartz monzonite. The remaining fragments are from latite, quartzite, aplite, rhyolite, and probably granodiorite porphyry. The fragment size ranges from that of sand to boulders, some as much as 5 feet in diameter; the bulk of the fragments are more than 1 foot in diameter. Intercalated with these dominantly granitic fanglomerates are a few beds derived chiefly from the latitic lavas, but they also include minor amounts of quartz monzonite and rhyolite. These beds are blue gray, in contrast to the brick red of the fanglomerates derived from the quartz monzonite; in the Cloudburst Wash, fanglomerates derived from the lavas comprise the bottom 150 feet of the section, and are commonly intercalated in the granitic fanglomerate as far east as McKinney Dam, sec. 29, T. 8 S., R. 16 E. In addition, there are (1) a few beds of latitic sandstone as much as 3 feet thick, (2) several beds consisting of mafic volcanic fragments as much as 3 inches in diameter in a sandstone matrix derived from the Precambrian granitic rocks, and (3) one bed of rhyolite tuff as much as 5 feet thick.

The fanglomerate in the north-central part of sec. 27, T. 8 S., R. 16 E., comprises well-bedded boulder fanglomerates and lesser amounts of intercalated coarse- to medium-grained sandstone. Fragments derived from the quartz monzonite greatly predominate, but some beds contain mostly lava fragments. This local sequence is exceptionally well bedded and locally crossbedded.

The fanglomerate west of the Mammoth fault in the central part of sec. 16 , T. 8 S., R. 16 E., consists mostly of volcanic fragments; scattered granitic fragments are estimated to comprise less than 1 percent of the unit. In contrast, the fanglomerate east of the Mammoth fault consists roughly of equal amounts of granitic and volcanic fragments, and in addition, sparse quartzite and limestone cobbles and boulders. In the NE $1 / 4$ of sec. 16 , north of the fault that strikes east and dips $40^{\circ} \mathrm{S}$., the fanglomerate, like that west of the Mammoth fault, is composed of volcanic fragments and little else.

Similar lithologic variations occur in Tar Wash east of the Mammoth fault, chiefly in the southwest corner of sec. 15, T. 8 S., R. 16 E. Here the sinuous north west-dipping fault separates two facies. Only granitic and volcanic fragments-both separated and mixed-occur in the fanglomerate southeast of the fault, whereas the fanglomerate northwest of the fault contains numerous conspicuous limestone, 
quartzite, and sandstone fragments. Fanglomerates of this latter type are not known west of the Mammoth fault.

The lithology of the fanglomerate south of the San Manuel fault differs along the strike. The great bulk of the section exposed in Cloudburst Wash was derived from the quartz monzonite. Along the strike of the beds southward in Tucson Wash, boulders from the quartz monzonite predominate, but sufficient volcanic material is admixed for the two sections to appear different, and locally, beds near Tuscon Wash contain more than 90 percent volcanic fragments. Such areas are in the $\mathrm{N} 1 / 2$ sec. 4 and NE $1 / 4$ sec. 5, T. 9 S., R. 16 E.

Sandstones composed of volcanic debris occur here and there in Cloudburst fanglomerate. They consist of medium- to coarse-grained sandstone derived almost wholly from the latite. The sandstones are dark gray to black, well bedded, well sorted, and commonly crossbedded. Thin sections reveal abundant small lithic fragments of latite and minor amounts of other material, chiefly feldspar and quartz. The thickest stratigraphic interval of latitic sandstone, about 1,000 feet, occurs in Tar Wash, northeastward from a point about 1,400 feet east of the Mammoth fault. Attempts to follow this interval southward were unsuccessful. Beds persist locally as far south as Tucson Wash, but apparently they, too, grade laterally into the typical fanglomerates.

The monolithologic sedimentary breccias occur in secs. 15 and 16 , T. 8 S., R. 16 E. They range in thickness from about 10 to 175 feet and in length from a few hundred feet to about a mile. The underlying and overlying contacts of the breccias are conformable and delightfully sharp. Laterally, however, the breccias grade into typical fanglomerate by a gradual mixing of foreign cobbles and boulders.

The breccias consist of largely angular fragments of Precambrian quartzose granitic rocks, chiefly granodiorite, as much as $11 / 2$ feet in diameter, in a comminuted matrix of the same granitic material as the fragments. The ratio of fragments to matrix is high. Sedimentary structures do not exist within the breccia, and each breccia mass is one bed. The breccias, therefore, appear more tectonic than sedimentary, and indeed, first impressions suggest brecciated fault slivers. However, the geologic map clearly reveals the conformable bedlike nature of the breccias.

Here and there the breccias are cut by sandstone dikes. The largest observed is about 2 feet wide. One dike, exposed on the wall of a gulch, extends downward into the underlying fanglomerate with which it merges, and the composition of the sandstone dike is the same as the finer grained material in the fanglomerate. The relations strongly imply that the fanglomerate was the source of the dike and that the weight of the breccia bed resting on a saturated fanglomerate forced 
the finer grained material into a fracture in the overlying breccia.

One unusual breccia bed contains remnants of a diabase dike. The dike is segmented, and each segment is askew with respect to the others, yet close enough to its neighbors that the general continuity of the original dike is readily recognized. Certainly, this breccia bed must have moved largely in mass, and the presumption is strong that it, as well as the others, was emplaced through gravity.

There is no problem of source for the breccias. The bedrock for several miles to the west and northwest is Precambrian granitic rock, cut by diabase and aplite dikes.

The volcanic rocks in the Cloudburst Formation comprise latite flows, flow breccias, related dikes and small intrusives, and here and there, intercalated beds of sedimentary material too thin to separate on the scale of the regional map.

Textures of the latite range considerably from one flow or fragmental bed to another. The most common texture is porphyritic with a pilotaxitic (felty) groundmass. In addition, the following textures occur in flows: microcrystalline pilotaxitic, porphyritic with a microcrystalline groundmass, trachytic, and microgranular. A small intrusive mass in the NE1/4 sec. 17 , T. 8 S., R. 16 E., has a fine-grained hypidiomorphic granular texture. The phenocrysts are small; rarely do they exceed $2-3 \mathrm{~mm}$ in diameter.

The bulk of the latite is massive, but there are some fragmental rocks or breccias that are commonly oxidized brick red. The fragments show no signs of an explosive origin; hence, they are probably flow breccias. Locally, sections of massive latite are similarly oxidized. Some of these appear to be the tops of flows, and a similar origin is assumed for the others. Vesicles and amygdules are common. Some of the vesicles are stretched or otherwise distorted by flow. The amygdules consist of chlorite, epidote, quartz, chlorite-epidote, analcite, and montmorillonite-analcite. In the chlorite-epidote amygdules, the chlorite surrounds an epidote core. Similarly, the montmorillonite encloses the analcite. The analcite and montmorillonite-analcite amygdules occur in Cloudburst Wash in sec. 30, T. 8 S., R. 16 E.

The latite is composed of plagioclase, $\mathrm{K}$-feldspar, pyroxene, chlorite biotite, epidote, calcite, magnetite, hematite, leucoxene, apatite, and xenocrystic quartz. Of these, all the chlorite, epidote, calcite, and hematite, and at least part of the $\mathrm{K}$-feldspar and biotite, are secondary. The phenocrysts are characteristically pyroxene, now intensely altered; phenocrystic plagioclase is uncommon.

The great bulk of the pyroxene is altered to chlqrite and hematite. Truly fresh pyroxene (augite) occurs as euhedral crystals and $0.5 \mathrm{~mm}$ across the maximum dimension in a small instrusive mass in the $\mathrm{NE} 1 / 4$ 
sec. 17 , T. 8 S., R. 16 E. This pyroxene has a $2 V$ of about $40^{\circ}$, a birefrigence of 0.025 , and a $y$ index of 1.695 ; the $Z \wedge c$ is about $36^{\circ}$. On the basis of Hess' diagrams relating optical properties to chemical composition of the clinopyroxenes (Hess, 1949, p. 634), the atomic proportion of $\mathrm{Mg}$ to $\mathrm{Fe}$ to $\mathrm{Ca}$ is 43 to 23 to 34, which indicates a common augite. Properties of the pyroxene in the flows were not determined because of their altered condition and small grain size. In several flows, however, partly altered pyroxene crystals about 0.05 $\mathrm{mm}$ in diameter showed a maximum birefringence of 0.022 .

Most of the plagioclase is in microscopic laths that form the pilotaxitic texture of the flows. The composition of the plagioclase reflects a pervasive propylitic alteration. Presumably albite was the stable plagioclase under the alteration conditions, and the plagioclase became progressively more albitic as equilibrium was approached. Measured compositions range from $\mathrm{An}_{48}$ to $\mathrm{An}_{5}$. The former probably approximates the plagioclase composition before alternation, and the latter after alteration.

The K-feldspar occurs chiefly as anhedral crystals, mostly less than $0.05 \mathrm{~mm}$ in diameter, interstitial to the plagioclase. To a lesser extent, $\mathbf{K}$-feldspar replaces and rims the plagioclase. In a few slides, $\mathbf{K}$ feldspar is about as abundant as the plagioclase. In these slides, a little secondardy biotite is associated with the $\mathrm{K}$-feldspar, and the textural relations between $\mathrm{K}$-feldspar and plagioclase strongly suggest that the K-feldspar replaced the plagioclase. In several slides, small anhedral crystals of $\mathbf{K}$-feldspar are disseminated in chlorite pseudomorphs after pyroxene. Such $\mathbf{K}$-feldspar is presumably secondary.

Chlorite is the dominant mafic constituent of the rock; it occurs in pseudomorphic aggregates after pyroxene, in disseminated flakes of uncertain origin, and as amygdules. Biotite, which ranges from pale brown to nearly colorless, is sparse; it occurs in small disseminated flakes or shreds. Epidote is common in disseminated granules, in clots, and as amygdules, both separately and associated with chlorite. Calcite, identified through rapid effervescence with dilute hydrochloric acid, occurs in veinlets, disseminated grains, and aggregates. It is closely associated with epidote but is also independent. One would judge from their occurrence that both are stable calcian alteration products.

The rocks in secs. 30 and 31 , T. 8 S., R. 16 E., consist of a series of porphyritic vesicular and amygdaloidal latite flows, some of which are 30-40 feet thick, and one intercalated fanglomerate bed. The upper few feet of many of the flows are scoriaceous, oxidized brick red, and vesicular; some vesicles are elongated from flowage. The fanglomerate bed ranges from maroon to brick red and is composed of 
boulders and cobbles of latite, quartz monzonite, and minor amounts of quartzite. A few beds of volcanic sandstone are intercalated in the coarse material.

The age of the Cloudburst Formation has not been unequivocally determined. It is probably Late Cretaceous or early Tertiary, on the bases of lithologic correlation with the volcanic rocks and fanglomerate in Reed Basin, which is about 20 miles north-northeast of the quadrangle, and of a lead-alpha age determination of zircons from the granodiorite porphyry, fragments of which occur in the Cloudburst Formation.

In Reed Basin similar volcanic rocks and minor amounts of intercalated fanglomerate unconformably overlie Upper Cretaceous rocks of Colorado age. These same volcanic rocks near Christmas were intruded by a quartz diorite porphyry whose isotopic age by the $\mathrm{K}-\mathrm{A}$ method using biotite is 63 million years (corrected value) (Creasey and Kistler, 1962).

H. W. Jaffe, of the U.S. Geological Survey, determined the age of zircon concentrates from the granodiorite porphyry by the lead-alpha method to be 97-130 million years; this suggests that the porphyry is Cretaceous. Fragments of the porphyry are common in the fanglomerates of the Cloudburst Formation, and fragments of altered porphyry derived from the San Manuel ore deposit occur in the Cloudburst Formation southeast of the deposit in the area bounded by the San Manuel and Mammoth faults.

\section{INTRUSIVE RHYOLITE AND RHYODACITE}

The intrusive rhyolite and rhyodacite are not distinguished separately on plate 1 . Intrusive rhyolite occurs in two prominent plugs in the north-central part of the area and in one large and several small masses near the old town of Tiger. The larger masses of intrusive rhyodacite occur in secs. 4, 8, and 9, T. 9 S., R. 16 E., and in secs. 28 and 31 , T. 8 S., R. 16 E. In addition, about 20 other smaller masses of intrusive rhyolite and rhyodacite, mostly less than 300 feet in diameter, are scattered here and there, but chiefly in the Cloudburst Formation. Two large masses of intrusive rhyolite near the northern boundary of the quadrangle and two small masses in Tucson Wash (sec. 24, T. 8 S., R. 16 E.) protrude through the Gila Conglomerate. Apparently, they stood above the surrounding area, and the Gila was deposited around them.

The fresh fracture of the intrusive rhyolite is pinkish gray, and weathered surfaces are lighter hues of the same color. The intrusive rhyodacite is medium gray on a weathered surface and medium light gray on freshly fractured one. The color index of both rocks ranges from about 1 to 2 . 
The texture and structure in the rhyolite vary considerably from place to place. Flow banding is common. In general, the flow bands dip $70^{\circ}-80^{\circ}$ and strike at random. Intrusive rhyolite breccias are exposed on the surface near Tiger and in the St. Anthony mine around the margins of some of the rhyolite masses. Excellent exposures in the walls of Tucson Wash display a vertical intrusive breccia dike about 40 feet wide. Near the bottom of the wash, the dike consists chiefly of rhyolite fragments; higher on the slopes, more foreign fragments are included, but local patches are nearly all rhyolite; and near the top of the dike, foreign fragments predominate to the near exclusion of rhyolite. The wallrocks of the dike consist of Cloudburst fanglomerate composed entirely of volcanic detritus. Most of the foreign fragments in the breccia dike, however, are Precambrian granitic rocks. Mixed with these are minor amounts of other rocks, chiefly quartzite, which clearly show that the foreign fragments came from some bed in the Cloudburst Formation lying beneath the floor of Tucson Wash, rather than from the Precambrian bedrock itself. Presumably, breccia dikes of this sort are a product of gas transport under high pressures.

Similarly, the two northernmost rhyolite plugs exhibit explosive phases; both are flanked-particularly on the east-by tuffs. Locally, the rhyolite intruded the tuff, which indicates that the explosive phase preceded the intrusive. Tar Wash cuts the core of the southernmost of these two plugs and exposes a vertical section through a vent breccia. Besides altered and fresh rhyolite fragments, the vent breccia includes minor amounts of foreign material, such as quartzite, granite rocks, and fanglomerate, and blocks of Cloudburst fanglomerate about 35 feet across. The altered rhyolite fragments in the vent breccia contain appreciable amounts of montmorillonite.

Some of the rhyolite is felsitic, but most is porphyritic with a microcrytalline groundmass. Phenocrysts, which constitute as much as 10 percent of the rhyolite, comprise quartz, albite, K-feldspar, and minor amounts of biotite. The minerals of the groundmass and the felsitic rhyolite are partly microcrystalline. Quartz, alkali feldspar, and a few spherulites were recognized.

The intrusive rhyodacite contains white plagioclase and bronze biotite phenocrysts set in a medium-gray microcrystalline granular groundmass. This rock weathers to a medium light gray. The modal composition, by volume percent (average of three samples), is 92 percent groundmass, 6 percent phenocrystic plagioclase, 1.6 percent biotite, and less than 1 percent magnetite; a few crystals of accessory apatite were noted. The plagioclase, which occurs in laths as much as 2 by $5 \mathrm{~mm}$, has an average composition in the freshest rock of An ${ }_{35-40}$. 
Biotite occurs in plates, 1-3 mm in diameter, which include needles and irregularly shaped magnetite crystals. Biotite is altered to hematite and possibly to magnetite.

The groundmass is a microcrystalline aggregate of granular quartz and feldspar. Much of the groundmass feldspar is $\mathbf{K}$-feldspar, and the composition of the groundmass plagioclase is 10 percent or less An.

In altered rhyodacite, the albitized plagioclase is partly changed to sericite, and the biotite, to hematite and possibly magnetite. Much fine-grained "dust," which appears to be an alteration product but whose mineralogy is uncertain, occurs in some altered specimens.

The following table gives the chemical and normative composition of the intrusive rhyolite and rhyodacite. Nockolds' (1954) data for calcalkali rhyolites plus rhyolite-obsidians and for average rhyodacites plus rhyodacite-obsidians are included for comparison.

\begin{tabular}{|c|c|c|c|c|c|c|c|c|c|}
\hline \multicolumn{5}{|c|}{ Chemical analyses (weight percent) } & \multicolumn{5}{|c|}{ Norm (weight percent) } \\
\hline & 1 & 2 & 3 & 4 & & 1 & 2 & 3 & 4 \\
\hline 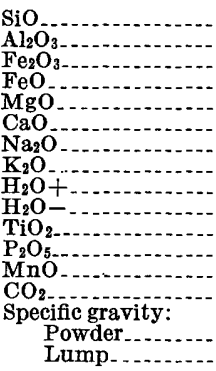 & $\begin{array}{c}77.2 \\
12.9 \\
.56 \\
.05 \\
.20 \\
.46 \\
2.7 \\
5.1 \\
1.2 \\
-1 . \\
.10 \\
.02 \\
.04 \\
.13 \\
2.60 \\
2.17\end{array}$ & $\begin{array}{r}73.66 \\
13.45 \\
1.25 \\
.75 \\
.32 \\
1.13 \\
2.99 \\
5.35 \\
.78 \\
.22 \\
.07 \\
.03 \\
\\
\\
\end{array}$ & $\begin{array}{c}66.7 \\
16.2 \\
3.2 \\
.11 \\
.60 \\
1.70 \\
4.4 \\
4.4 \\
1.1 \\
.9 \\
.64 \\
.20 \\
.02 \\
.09\end{array}$ & $\begin{array}{r}66.27 \\
15.39 \\
2.14 \\
2.23 \\
1.57 \\
3.68 \\
4.13 \\
3.01 \\
.68 \\
\hdashline .66 \\
.17 \\
.09 \\
\hdashline-\end{array}$ & $\begin{array}{l}\text { ob } \\
\text { an } \\
\text { an } \\
\text { wo } \\
\text { en } \\
\text { fs } \\
\text { mt }{ }_{1}\end{array}$ & \begin{tabular}{c}
41.0 \\
30.0 \\
23.1 \\
1.4 \\
2.35 \\
\hdashline .2 \\
\hdashline .15 \\
\hdashline .64 \\
\hdashline$r a c e$ \\
\hdashline 55
\end{tabular} & $\begin{array}{r}33.2 \\
25.1 \\
25.1 \\
5.0 \\
\hdashline .8 \\
\hdashline 1.9 \\
.5 \\
\hdashline .2 \\
\hdashline 51\end{array}$ & \begin{tabular}{c}
20.3 \\
26.1 \\
37.2 \\
7.0 \\
1.63 \\
\hdashline .6 \\
.6 \\
3.2 \\
.7 \\
.2 \\
.6 \\
37
\end{tabular} & \begin{tabular}{r}
20.8 \\
17.8 \\
35.1 \\
14.5 \\
\hdashline .2 \\
3.9 \\
1.3 \\
3.0 \\
1.4 \\
.3 \\
\hdashline \\
26
\end{tabular} \\
\hline
\end{tabular}

1. Intrusive rhyolite. Location: Sec. 15, T. 8 S., R. 16 E. Mammoth quadrangle, Pinal County, Ariz . Rapid analysis by $P$. L. D. Elmore and S. D. Botts (Creasey, 1965).

2 . Average of 22 calc-alkali rhyolites plus rhyolite-obsidians (Nockolds, 1954, p. 1012)

3. Intrusive rhyodacite, NW1/4 sec. 9, T. 9 S., R. 16 E., Mammoth quadrangle, Pinal County, A riz. Rapid analyses by P. L. D. Elmore, K. E. White, and S. D. Botts (Creasey, 1965).

4. Average of 115 rhyodacites plus rhyodacite-obsidians (Nockolds, 1954, n. 1014).

The rhyolite and rhyodacite are intrusive into the Cloudburst Formation and are overlain by depositional contact by the Gila Conglomerate. They are therefore younger than the Cloudburst and older than the Gila. Because the Cloudburst Formation is either Late Cretaceous or early Tertiary, the intrusive rhyolite and rhyodacite are similarly assigned. Somewhat similar rhyolitic rocks of about the same age have been recognized in the Klondyke quadrangle, which lies to the northeast and has a common corner with the Mammoth. Here Simons (1964) recognized a volcanic sequence (Horse Mountain Volcanics) of dominantly rhyolitic rocks including volcanic necks and vents. He considered these to be older than the volcanic rocks comprising the 
Galiuro Mountains and younger than rocks that unconformably overlie the Pinkard Formation of Late Cretaceous age. He therefore assigned these rhyolitic rocks to the Late Cretaceous or early Tertiary.

\section{TERTIARY SYSTEM}

\section{GALIURO VOLCANICS}

The Galiuro Volcanics of Tertiary age occur in two strips along the eastern edge of the quadrangle. The northern exposure, which is in secs. 16 and 21, T. 8 S., R. 17 E., is about 6,000 feet long (north) and a maximum of 1,000 feet wide. It is a westward extension of the Galiuro Volcanics (Simons, 1964), which make up much of the Galiuro Mountains, and exposures are continuous with those in the mountains. The southern strip, which is in sec. 21 , T. 9 S., R. 17 E., is only the western edge of an isolated patch of volcanic rocks entirely enclosed in Gila Conglomerate about 3 miles west of the volcanic bedrock in the Galiuro Mountains. The outcrop of this southern area within the bounds of the quadrangle is only about 2,000 feet long (north) by 300 feet wide. Because both of these occurrences are merely fragments of the volcanic pile forming the Galiuro Mountains, and because the base of each is concealed by the overlap of the Gila Conglomerate, the thickness within the quadrangle has little significance, and therefore no attempt was made to measure it. The relations shown on the geologic map, however, indicate that about 700 feet of these volcanic rocks are exposed within the quadrangle.

The Galiuro Volcanics unconformably overlie the Glory Hole Volcanics of Late Cretaceous to early Tertiary age and are unconformably overlain by the Gila Conglomerate. Neither unconformity is readily apparent from the geologic map because of the small outcrop areas within the quadrangle. The unconformity between the Glory Hole and Galiuro Volcanics is described more fully in the section on the Glory Hole Volcanics. The unconformity between the Galiuro Volcanics and the Gila Conglomerate is marked by hundreds of feet of topographic relief and by a difference in dip of about $20^{\circ}$. The Galiuro Volcanics were faulted early in the Basin and Range period of deformation, and the Gila, which accumulated in the basins formed by this deformation, progressively overlaps the volcanic bedrock. Along the eastern edge of the quadrangle, the Gila dips about $10^{\circ}$ westward or basinward, whereas the Galiuro Volcanics dip about $10^{\circ}$ eastward or toward the mountains.

The northern area of Galiuro Volcanics, undivided on plate 1, consists of a lower unit of andesite estimated to be $200-500$ feet thick, overlain successively by (1) about 30 feet of lapilli tuff and tuffaceous volcanic breccias, (2) about 30 feet of black vitrophyre, and (3) more 
than 150 feet of what is probably a welded tuff. The entire sequence above the andesite may be different parts of ash flow.

The andesite is a pale-lilac-gray lava marked here and there by vesicles and amygdules, especially near the top of the unit. It is porphyritic with an aphanitic groundmass, and consists of phenocrysts of plagioclase and altered pyroxene set in a pilotaxitic groundmass of plagioclase lath and minor amounts of pyroxene. The pyroxene is chiefly a light-yellow-green clinopyroxene and is in crystals $0.5-0.1$ $\mathrm{mm}$ in length. In addition, there are minor amounts of a somewhat fibrous mafic mineral whose optical properties suggest an orthopyroxene.

Overlying the andesite is a buff-colored section ranging in lithology from lapilli tuff to tuffaceous volcanic breccias. The unit consists of crystals and fragments of volcanic rocks ranging in size from 1 or $2 \mathrm{~mm}$ to as much as $25 \mathrm{~cm}$ set in a matrix of volcanic ash. Accidental fragments are common. The crystal fragments are mainly plagioclase, but some are biotite, quartz, and iron ores. The rock fragments consist of pumice and a variety of porphyritic volcanic rocks including andesite or latite. In addition, a few fragments of a quartz-mica hornfels of unknown source were noted.

A black vitrophyre overlies the tuffaceous breccia. The vitrophyre is a deep brown to black rock composed of about 20 percent crystals and crystal fragments set in a glass matrix. The microscope reveals in the glass a beautifully preserved relict fragmental structure in which the detailed texture of individual fragments is clearly preserved. Obviously, most of the original fragments were pumice. The crystals and crystal fragments are largely plagioclase, but they include pyroxene and biotite and a few crystals of quartz, sphene, and zircon.

The vitrophyre grades upward abruptly into a pinkish-gray laminated and vuggy volcanic rock that appears to be a welded tuff. On fresh fracture, the volcanic rock exhibits somewhat contorted gray and pale-maroon layers and consists of abundant untwinned plagioclase crystals and crystal fragments set in a felsitelike groundmass. In addition to crystals of plagioclase and shreddy biotite, the welded tuff contains lenticular granoblastic aggregates of plagioclase crystals, each with sutured boundaries. The texture of the aggregate suggests recrystallization. Iron ore, sphene, and zircon are present as minor accessories. The groundmass appeared to be partly devitrified.

Simons (1964, p. 92) tentatively assigned the Galiuro Volcanics to the middle Tertiary. In the Klondyke quadrangle, which joins the Mammoth on the northeast, the Galiuro Volcanics covered the deeply eroded surface of the Copper Creek Granodiorite. The isotopic ages by the K-Ar method of the biotite and hornblende from the grano- 
diorite are 68 and 66 million years, respectively; hence, the Galiuro Volcanics are early Tertiary or younger.

The Galiuro Volcanics predate the Basin and Range period of deformation because they comprise the rocks in some of the ranges. The time when the deformation started is uncertain, but some of the sediments that collected in the basins have been dated by vertebrate remains as Pliocene and Pleistocene. The minimum age of the Galiuro Volcanics, therefore, is Pliocene, and they may be somewhat older.

About 12 miles south of the Mammoth quadrangle on the west side of the San Pedro Valley, terrestrial deposits involved in the Basin and Range deformation have been dated as middle Tertiary by a single fossil rhinoceros (Chew, 1952). Similar-appearing rocks on the east side of the valley are unconformably overlain by the Galiuro Volcanics that occur in the Mammoth quadrangle.

These relations suggest that the volcanics are middle Tertiary or younger, and are older than the basin deposits of Pliocene age. They cannot be dated more closely than this.

\section{TERTIARY AND QUATERNARY SYSTEMS}

\section{GILA CONGLOMERATE}

The Gila Conglomerate of Pliocene and Pleistocene age was named by Gilbert (1875, p. 540-541) for the basin deposits exposed along the gorges of the upper Gila River and its tributaries in the Gila Valley about 60 miles east of the map area. The dominant rock in the type area is conglomerate, but finer grained sediments and lava flows form part of the section. Subsequently, the name has been used widely for basin deposits of essentially similar rocks of Pliocene or Pleistocene age that fill the basins formed during the Basin and Range period of deformation. The basin deposits in the San Pedro Valley that are called Gila Conglomerate are contiguous in part with the deposits of the type area, whereas deposits called Gila in some other basins are isolated. Use of the name Gila Conglomerate for the widespread, and commonly disconnected, basin deposits of Pliocene or Pleistocene age is criticized by Heindl (1963), who asserts that the formation rank of the Gila Conglomerate tends to mask the sequence of alluvial deposits and to oversimplify a complex history. He proposes that Gila Conglomerate be replaced by Gila Group, and he uses Gila Group for his discussion of part of the Mammoth quadrangle. The author prefers to use Gila Conglomerate for the Mammoth quadrangle at this time because subdivision of the Gila Conglomerate has not produced units that meet the requirements of formations. The need for a general term to cover the basin deposits eixsts. Whether Gila Conglomerate or Gila Group is used would seem to depend logically on the extent to which the local 
deposits are subdivided according to the widely accepted code of stratigraphic nomenclature published by the American Association of Petroleum Geologists in 1961.

There are further differences between Heindl's stratigraphic treatment of the basin deposits in the Mammoth quadrangle and those here stated. Heindl (1963) mapped a strip about 5 iniles wide across the Mammoth quadrangle and subdivided the Gila into three formations, the lowest of which comprises three members. In order of increasing age, they are the Sacaton, Quiburis, and San Manuel Formations. Here also the Gila is subdivided, but into three lithologic facies that do not coincide with Heindl's formations.

Fundamental to this disagreement is the differing interpretation of the lowest exposed basin-fill conglomerates on opposite sides of the San Pedro Valley. Heindl (1963) believes that the conglomerates on the west side of the valley (San Manuel Formation) are older than those on the east (Quiburis Formation) and that the San Manuel Formation grades upward into the Quiburis. However, the sediments from opposite sides of the valley seem to interfinger, and nothing indicates an age difference. Heindl also includes pediment gravels in the Gila Group as the Sacaton Formation, whereas here they are excluded from the Gila Conglomerate.

The Gila Conglomerate covers all but a minuscule part of the eastern two-thirds of the quadrangle. The thickness of the Gila is not known. Schwartz (1953, p. 14) reported a maximum of 1,208 feet near the San Manuel ore deposit. Undoubtedly, the thickness increases towards the valley, and Schwartz reported that east of Tiger near State Highway 77, the Santa Maria Mining Co. drilled through 2,020 feet of alluvium and Gila Conglomerate without penetrating bedrock. Presumably, the general thickness is several thousand feet, but inliers of bedrock that protrude through the Gila indicate that the thickness varies from place to place, depending on the configuration of the bedrock surface beneath the San Pedro Valley. Such inliers occur in sec. 19, T. 10 S., R. 18 E., and secs. 21 and 29 , T. 9 S., R. 18 E.

The Gila Conglomerate rests on Precambrian granitic rocks, aplites, and diabase; on Paleozoic rocks; and on Cretaceous or Tertiary conglomerates and volcanic rocks. In the central part of the San Pedro Valley, north of the eastward projection of the Mogul fault, the inlier of Escabrosa surrounded by Gila in the Black Hills, sec. 19, T. 10 S., R. 18 E., suggests that the entire Paleozoic section may lie beneath the Gila. This possibility is further supported by the presence of Paleozoic rocks in Putnam Wash, 6 miles north of the quadrangle, striking into that part of the Mammoth quadrangle underlain by Gila.

236-465 0-67- -5 
The Gila Conglomerate is overlain by Quaternary pediment gravels and by still younger alluvium along the San Pedro River and its tributaries.

The subdivisions of the Gila are based on lithologic differences, but the stratigraphic relations of the subdivisions vary from one local area to another because the lithology changes vertically and laterally. Deformation, which continued during at least part of the time during which the Gila Conglomerate accumulated, resulted in local unconformities and presumably influenced the amount and character of the accumulating debris.

The indurated conglomerate unit overlaps the bedrock on both the west and east sides of the San Pedro Valley. On the west side it is unconformably overlain by the unconsolidated sand and conglomerate unit as far south as this latter unit can be distinguished. The indurated conglomerates, however, toward the central axis of the valley, grade laterally into the unconsolidated marls and limy silts unit. This lateral lithologic change is surprisingly rapid; in the vicinity of Copper Creek Canyon the complete change from boulder conglomerates to marls occurs within a quarter of a mile. The facies change is accomplished through interfingering of the two rock types, rather than through lithologic change within specific beds. 'The transition is so sudden that it is strongly reflected in the topography and is easily recognized on the topographic map.

From the relation of the indurated conglomerate to the marls and the unconsolidated conglomerate and sandstone, one would expect the unconsolidated conglomerate and sandstone to overlie the marls unconformably. If this relation does exist, which it may, it was not recognized. So far as could be observed, the marls appeared to grade into the unconsolidated sands and conglomerates through interfingering of the different lithologic types. The contact between the two units in secs. 2, 9, and 10, T. 10 S., R. 17 E., and in secs. 26 and 35, T. 9 S., R. 17 E., is gradational, and its location purely arbitrary. Northward from this contact the unconsolidated sand and conglomerate becomes progressively more conglomeratic, and the northern part is predominantly conglomerate.

The indurated boulder and cobble conglomerate unit of the Gila consists of overlapping and coalescing alluvial fans that grew eastward and westward from the uplifted mountain ranges into the basin between. Like other typical fans, these display a wide range of fragment size, sorting, crossbedding, and lithology. Differences in lithology from one fan to another presumably reflect differences in bedrock from one source area to another. Beds on the west side of the valley dip $15^{\circ}-40^{\circ}$ eastward, and beds on the east side dip $5^{\circ}-15^{\circ}$ 
westward. These dips reflect both the initial dip and subsequent local deformation, some of which occurred before the deposition of the next younger strata of the Gila.

Exclusive of the associated sedimentary breccias, the indurated conglomerate is composed of detritus ranging in size from that of silt to boulders, but the great bulk of the unit is cobble and boulder conglomerates from the older Precambrian granitic rocks and Tertiary volcanic rocks and lesser amounts from the younger Precambrian Apache Group and Paleozoic rocks. Some individual beds are predominantly one type or another, and others are mixed. Some of the beds are tuffaceous, and several thin predominantly tuffaceous beds were noted. Boulders as much as 15 feet in diameter occur in the conglomerates that directly overlie the bedrock on the west side of the valley. This unit is well bedded and indurated. Bedding ranges in thickness from 1 or 2 inches to about 50 feet. Some individual beds are well sorted, but many are not. The cementing material is carbonate and silica; in one thin section the grains were cemented by a zeolite.

In secs. 5, 6, 7, 8, and 9, T. 9 S., R. 16 E., the indurated conglomerate includes several beds or lenses of a distinctive sedimentary breccia which is distinguished on the geologic map, plate 1. The sedimentary breccias comprise four bedlike masses whose thicknesses range from about 25 to 125 feet and one lenslike mass whose thickness is estimated at 400-600 feet and strike length at about 4,500 feet. Except where broken by faults, the breccia masses are conformable with the underlying and overlying conglomerates. These breccias are composed of one, two, or three rock types; the fragments are angular and jumbled and, unlike the surrounding conglomerates, show no indication of water transport or sorting. The ratio of angular fragments to matrix is surprisingly high. The matrix consists of smaller angular fragments and rock flour similar in composition to the fragments. The large lens is a composite breccia mass; it contains lenses or irregularly shaped masses that are monolithologic. Some of these irregularly shaped masses appear to be blocks as large as 20 by 50 feet in which the original bedding is consistent throughout, despite a generally crackled condition in which no area more than 2 feet across is without a fracture. Such blocks must have been emplaced as a unit.

The large lens is cut by numerous sandstone and pebble dikes. The dikes cut all the breccia types, but chiefly the diabase. They range in width from about 1 inch to 4 feet, and observed lengths are estimated at 50 feet. The material composing some dikes must have traveled upward, for it is composed of material like either the enclosing rocks or the underlying breccias. 
The four sedimentary breccia beds are composed of limestone, quartzite, diabase, and a diorite, which is probably a facies of the diabase. The longest bed in the central part of sec. 8 -the faulted one-is estimated to consist of 85 percent limestone and 15 percent combined diabase and quartzite.

In the composite lenslike mass four breccia types occur: diabase and diorite, limestone, quartzites, and banded hornfels. The diabase breccias, which are a dark greenish gray, consist of angular diabase fragments in a comminuted matrix of diabase. Limestone breccias are about as abundant as the diabase, and together they comprise the bulk of the large lens. The limestone breccias tend to be more coherent; original bedding can still be recognized in large blocks that are intimately crackled or fractured. Some limestone breccias were derived from the Escabrosa Limestone; others in which the limestone is impure probably were derived from the Martin. Here and there small masses of quartzite breccia occur; they are not nearly so abundant as the limestone or diabase. In general, the fragments in the quartzite breccias are much smaller, and the impression is that of much more intense brecciation.

Because the bulk of the indurated conglomerate in the area west of the San Manuel mine came from Precambrian granite rocks and Tertiary volcanic rocks, the contrasts in source material with the breccias derived from Paleozoic rocks and from the younger Precambrian Apache Group is striking. To try to obtain some concept of the origin of these breccias, Creasey (1965) subdivided the enclosing Gila Conglomerate on the bases of the dominant rock types. This study shows one highly significant fact: the breccias are included in a thick lens (probably a fan) of Gila Conglomerate in which fragments derived from the same sources as the breccias (Paleozoic racks and the Apache Group) are common, whereas the Gila overlying and underlying this lens or fan is virtually free from these rock types. Obviously, the breccias and the related enclosing Gila shared the same source areas, and these source areas were for the most part different from the Gila above and below the breccias. Any origin proposed for the breccias must take into account the obvious consanguinity of the enclosing Gila. This relation and the conformity of the breccias and the enclosing Gila led Creasey to propose a landslide or mudflow origin for the breccias.

\section{QUATERNARY SYSTEM}

\section{GRAVELS}

The Quaternary gravels, which veneer pediments produced by erosional cycles older than the present one, occur here and there in irregularly shaped patches overlying the Gila Conglomerate west of the San 
Pedro River from the northern to the southern border of the quadrangle. These patches are the erosional remnant of a much broader veneer that at its maximum development must have covered most of the Gila Conglomerate and very possibly much of the contiguous bedrock. In all places these pediment gravels lie above the level of the alluvium in the adjacent washes, and it is this relation to the alluvium that permits their distinction.

The pediment gravels are largely unconsolidated poorly sorted sheets of boulders and cobbles. Most of the remnants, which cap the interfluves between the larger washes, still possess the smooth, even surfaces of the original pediments. Others are the "roots" of channels that gouged into the underlying Gila and bedrock well below the general level of cut surface of the pediments. In the channel gravels, crossbedding, cut-and-fill features, and crude bedding were observed.

No attempt was made to record thicknesses of the gravels remaining. The geologic map shows that the thickness probably nowhere exceeds 100 feet, and that the average is probably much closer to 20 feet.

The pediment gravels are not in all places easily distinguished from the underlying Gila Conglomerate. Where the pediment gravels are underlain by the boulder or cobble conglomerate unit of the Gila, the difference between the pediment gravels, which contain reworked Gila, and the Gila, is subtle; this subtlety is emphasized by the small angular discordance between the two and, commonly, by poorly exposed contacts. Where erosion has not supplied vertical sections along the walls of the gulches, the distinction may not always be made, and possibly some pediment gravels were overlooked.

A well-developed dark-red soil formed at the top of the pediment. This soil profile, which probably averages at least 2-3 feet in thickness, was of great help in the recognition and separation of the pediment gravels; where gulches were sparse or absent, it was accepted as an indication of the pediment. In the central part of the quadrangle the dark-red soil occurs only in widely scattered patches on the highest parts of the interfluves. The pediment therefore appears to be dissected to a depth of 20-30 feet, the pediment gravels being stripped almost completely, and the Gila Conglomerate exposed.

\section{ALLUVIUM}

The Quaternary alluvium consists of unconsolidated sand and gravel that carpets all the streambeds from the smallest gulch to the wide flood plain of the San Pedro River. On the geologic map, however, alluvium is shown only along the San Pedro River and the major tributaries. Most of the alluvium is along the flood plain of the San Pedro River, which ranges in width from $1 / 2$ to 1 mile. The river itself is incised in the flood plain to depths estimated at about 20 feet. According to Bryan (1926), this renewed erosion started in 1883. 


\section{ROCKS OF UNKNOWN AGE-GRANITE}

On the east side of the San Pedro Valley just north of Whitlock Wash in sec. 29, T. 9 S., R. 18 E., a small mass of fine-grained quartz monzonite protrudes through the Gila Conglomerate. The mass is roughly circular and about 300 feet in diameter. The quartz monzonite was obviously a hill around which the marls and silts of the Gila accumulated, for fragments as much as 2 inches across of the quartz monzonite are included in the immediately adjacent Gila. The contrast between the fine-grained Gila and the quartz monzonite clasts is striking.

The quartz monzonite has a fine-grained hypidiomorphic granular texture. On casual inspection it appears to be porphyritic because crystals of poikilitic $\mathbf{K}$-feldspar as much as $5 \mathrm{~mm}$ in diameter occur throughout a rock whose average grain size is less than $1 \mathrm{~mm}$.

A single thin section suggests that the rock is composed of quartz (33 percent), plagioclase ( 26 percent), K-feldspar ( 30 percent), muscovite ( 5 percent), biotite ( 5 percent), and about 1 percent combined opaques and minor accessory minerals, including zircon and magnetite. Although the rock appears perfectly fresh in hand specimen, the thin section reveals that the plagioclase is heavily sericitized and rimmed with unaltered plagioclase, the $\mathrm{K}$-feldspar is heavily impregnated with an alteration dust of unknown composition, and the biotite is partly chloritized. The plagioclase is either albite or oligoclase; the alteration makes an accurate compositional determination not only difficult but of little merit.

The age of this quartz monzonite and its relation to rocks in the quadrangle other than the Gila Conglomerate are unknown. Its finegrain size, lack of deformation, and only slight alteration suggest that it is probably Mesozoic or Cenozoic in age.

On the geologic map the quartz monzonite is designated granite. This is to avoid confusion with the Precambrian quartz monzonite; besides, such a small exposure does not merit a formal geologic name.

\section{STRUCTURE}

\section{SUMMARY OF PRINCIPAL STRUCTURAL EVENTS}

The following paragraphs contain a brief summary of the principal structural events for this part of Arizona. Evidence of all the periods of deformation established for southeastern Arizona is not recognized in the rocks remaining in the Mammoth quadrangle. Following the summary are descriptions of the structures recorded in the rocks of the Mammoth quadrangle. 
The older Precambrian rocks of Arizona record one or more periods of deformation of sufficient intensity to produce isoclinal folds, pronounced foliation, and widespread metamorphism to the greenschist and amphibolite facies. Widespread intrusion of granitic rocks either followed or accompanied the late stages of this deformation. These granitic rocks, which intruded the metamorphic rocks in many places, are not gneissic, which indicates they did not yield to a pervasive deformation. They are, however, cut by strong older Precambrian shear zones and joints. The granodiorite and quartz monzonite (Oracle Granite of Peterson, 1938) in the Mammoth quadrangle are examples of such rocks.

The younger Precambrian Apache Group accumulated on a remarkably level erosion surface cut across the upturned edges of these older rocks. The Apache Group records only mild deformation in comparison with that of the older Precambrian rocks. The strongest deformation occurred some time after the deposition of part, or all, of the Troy Quartzite, perhaps at the same time as intrusion of stratiform diabase masses that locally inflated the section.

Following the deposition oi the Apache Group, regional upliff, erosion, and subsidence are recorded by the unconformities separating (1) the Apache Group from the Troy Quartzite and (2) the Troy Quartzite from the Bolsa Quartzite which is Middle Cambrian in age. There is no evidence of a period of intense deformation separating the Precambrian from the Paleozoic.

During the entire Paleozoic Era, the area was structurally quiet. Epeirogenic uplifts and subsidence are recorded by longtime breaks between some of the formations, but the entire Paleozoic section is nearly conformable. The era concluded by emergence followed by a long period for which we have no sedimentary record and therefore little, if any, insight into the structural paroxysms.

The Triassic and Jurassic Periods passed, leaving little or no record of what transpired. In recent years, however, detailed geologic mapping aided by isotopic age determinations have discovered scattered remnants of Mesozoic (and possible Mesozoic) volcanic rocks in southeastern Arizona. Gilluly (1956) recognized granitic rocks that were intruded during this period, and granitic intrusions commonly attest to deformation. Apparent structural and presumably topographic relief existed before the invasion of the Comanche seas, for the Lower Cretaceous Bisbee Group rests on Precambrian Pinal Schist and granite within 2 miles of Paleozoic rocks fully 4,000 feet thick (Gilluly, 1956, p. 67). In many places, however, Cretaceous rocks are missing, and here Mesozoic deformation has not been differentiated from Cenozoic deformation. 
The deposition of Lower and Upper Cretaceous rocks in south eastern Arizona, although not in the same areas, permitted records of intense deformation at two or more times in the post-Early Cretaceous and pre-Pliocene interval. An early period of deformation produced thrusts and overturned folds, such as those in the Dragoon Mountains and probably in the Dos Cabezas, and pronounced folds and faults elsewhere. A wide variety of granitic rocks and porphyries was emplaced during this period, and most of the fabulous mineral deposits of the southwest formed. In the Mammoth quadrangle, the granodiorite porphyry, the San Manuel deposit, and movement on the Mogul fault all date from this period.

A later period of thrusting produced the San Xavier thrust fault in the Sierrita Mountains (Cooper, 1960). The San Xavier thrust fault is younger than the ore deposits in the Pima district, which includes prophyry copper deposits similar to San Manuel. The age of the thrusting is not precisely known, but the San Xavier thrust is cut by andesite dikes whose isotopic age by the $\mathrm{K}$-Ar method on biotite is 24 million years (Creasey and Kistler, 1962).

The Pliocene and younger deformation (Basin and Range period) consisted of normal faults (chiefly high angle), tilting or gently warping, and monoclinal folds. It blocked out the present basins and ranges. Tension seems to have been the dominant force; nowhere is there evidence of widespread compression. In the Mammoth quadrangle the San Manuel and Mammoth faults moved at this time.

\section{STRUCTURES IN THE MAMMOTH QUADRANGLE}

The older Precambrian structures are in the granodiorite and quartz monzonite, and consists of sheared zones and joints, many of which are occupied by diabase or aplite dikes. These structures trend northwest and northeast, and dip at high angles. The northwest trend is dominant, but no age distinction between the two directions was recognized. Aplite and diabase dikes occupy both directions, and the crosscutting relations are mutual.

Banerjee (1957) thought that these structures were formed at two different times: the northwest-trending fractures during the Precambrian and the northeast-trending fractures during the Iurassic or Cretaceous. It is noteworthy that diabase and aplite dikes occupy both the northwest- and northeast-trending fractures, whereas the granodiorite porphyry associated with the San Manuel ore deposit occupies only the northeast-trending fractures. This suggests a second generation of the northeast-trending fractures before the intrusion of the porphyry, for had they existed in Precambrian time, they probably would have been intruded by diabase or aplite. Only the aplite and 
diabase form compound dikes, and these in the northwest-trending fractures; this suggests that the porphyry was not intruded into Precambrian structures.

The younger Precambrian structures, which are those shown by the Apache Group, consist of inflation by stratiform diabase intrusives, foliation in the Pioneer Formation, and those structures implied by a pronounced unconformity at the top of the Apache Group. The diabase spread laterally in the weaker thin-bedded units, specifically the upper member of the Pioneer and the upper member of the Dripping Spring Quartzite. Although there are many examples of crosscutting contacts, for every foot of diabase contact that crosscuts beds there are at least a thousand parallel to bedding. The thickness of the diabase is a measurement of the amount of inflation of the stratigraphic section. The thickness of the diabase varies from place to place, but the average is estimated to be about 300 feet, and the maximum, about 600 feet.

The Pioneer Formation in sec. 30, T. 10 S., R. 16 E., has a pronounced cleavage that is discordant to the bedding. The strike of the cleavage ranges from N. 45 E. to east-west, and dips are inclined north and south. The cleavage is missing from the siltstones and shales of the overlying Cambrian rocks and therefore it probably formed during the Precambrian. It may be a very local structure related to the intrusion of the diabase. The mild metamorphism in the Apache Group, in which quartz-feldspar rocks locally are altered to quartzsericite, is pre-Paleozoic and probably related to the intrusion of diabase. This metamorphism supports the concept that the heat and force generated by the diabase intrusion produced the foliation.

The unconformity at the top of the Apache Group was formed during two separate periods. This is demonstrated 35 miles to the northeast by 700 feet of Troy Quartzite, which lies between the Precambrian Apache Group and the Cambrian Bolsa Quartzite, and which is bounded top and bottom by pronounced unconformities. In the Mammoth quadrangle both these unconformities are represented by the one unconformity between the Apache Group and the Bolsa Quartzite. The Troy northeast of the Mammoth quadrangle probably was deposited over the area of the Mammoth quadrangle and was entirely removed during the post-Troy and pre-Bolsa erosional period.

Even though the Apache Group and the Paleozoic rocks are nearly conformable, the uplift and subsequent erosion in the two-generation unconformity that separates them was sufficient to expose coarsegrained diabase that probably crystallized at least a thousand feet below the surface.

The entire Paleozoic section in the Mammoth quadrangle is nearly conformable. Nevertheless, significant time breaks occur between 
formations, such as the break between the Middle and Upper Cambrian Abrigo Formation and the Middle and Upper Devonian Martin Formation. These breaks resulted from gentle relative uplifts accompanied by a minimum of erosion followed by gentle subsidence.

Igneous activity was absent in the Mammoth quadrangle during the Paleozoic Era, and virtually absent in all parts of southeastern Arizona.

So far as known from the rock record in the Mammoth quadrangle and adjacent areas, no rocks were deposited and no igneous activity occurred during the Triassic and Jurassic Periods. The only data on this interval for the Mammoth quadrangle come from the relation of the Cretaceous(?) American Flag Formation to the Paleozoic rocks. Pronounced structural elements, such as folds and faults that occur in Paleozoic rocks, are absent in the American Flag Formation. This formation, however, does unconformably overlie the Paleozoic rocks. If the American Flag Formation is rotated to the horizontal, the Paleozoic rocks dip gently, perhaps a few degrees west, in contrast to their present eastward dip.

The post-Early Cretaceous and pre-Pliocene deformation, which accounts for most of the structures in the Mammoth quadrangle, is recorded by the rocks (1) southward from the Mogul fault and (2) northward from the San Manuel fault. These areas will be considered separately in the following paragraphs.

Sometime following the accumulation of the American Flag Formation, this formation, the underlying Paleozoic rocks, and the Apache Group were inclined at moderate to steep angles eastward. Because the entire sequence is homoclinal, there is no way to determine unequivocally whether these rocks were folded or simply tilted. The structures west of the $3 \mathrm{C}$ Ranch perhaps give some insight into this deformation, for here the Escabrosa Limestone is thrust over the Martin Formation, other Escabrosa, and the American Flag Formation. The thrust indicates compression, but the compression may be due to local forces generated by movement along the Mogul fault rather than to the regional deformation that tilted the rocks. Furthermore, it is not known whether the regional tilting and the movement on the Mogul fault occurred concurrently or sequentially. The thrust, however, at the base of the Cloudburst Formation, which is only a few miles to the north, probably dates from this period and supports the concept of compression.

The Mogul is a west-northwest-striking high-angle right-lateral normal fault. It dips southward at about $60^{\circ}$. The Apache Group, Paleozoic rocks, and the American Flag Formation on the hanging wall have been moved against the Precambrian quartz monzonite (Oracle Granite of Peterson) on the footwall. 
The main break of the fault is sharply defined by the juxtaposition of sedimentary and granitic rocks. The fault plane itself is exposed in one of the opencuts at the Campo Bonito mine, and here the width of a hand covers the fault trace, but general brecciation in both walls extends beyond the limits of the exposure. The geologic map clearly shows the numerous concomitant branching and secondary faults, some parallel, on the hanging wall (south wall). Near the Mogul the complexity and number of faults that can be mapped depends chiefly on the scale of the base map. The number of these associated faults decreases rapidly with distance from the Mogul, and few are found beyond a mile away.

Undoubtedly, there are also numerous subsidiary faults along the footwall of the Mogul, but these cannot be recognized because of the uniform lithology of the quartz monzonite. Some measure of the intensity of the brecciation in the footwall is indicated by the difficulty of mapping individual diabase dikes closer to the Mogul fault than about 1,000 feet. This is not because the dikes end here, but rather because they are so segmented that mapping them is not feasible.

The vertical separation on the Mogul is down on the south, and the horizontal separation is right lateral. Along the entire trace of the Mogul fault in the southwest corner of the area, the older Precambrian quartz monzonite forms the footwall. This means that the stratigraphic throw at any point exceeds the stratigraphic thickness of all bedded rocks in the local section older than the one in contact with the fault. Where the American Flag Formation contacts the Mogul, therefore, the stratigraphic throw is at least 5,000 feet, which is the approximate total thickness of the stratigraphic section through the American Flag Formation. Despite this impressive stratigraphic throw, strike slip was the dominant movement if exposure of the Escabrosa Limestone in the Black Hills (sec. 19, T. 10, S., R. 18 E.) provides the general location of the Paleozoic section north of the fault.

In Putnam Wash about 6 miles north of the Mammoth quadrangle, the Apache Group and the overthrowing Paleozoic rocks dip and face eastward. To the south these rocks pass beneath the Gila Conglomerate, and on the assumption that the strike of the rocks remains the same, the Paleozoic section lies beneath the Gila Conglomerate somewhere near the town of Mammoth; the Black Hills lie along this same trend still farther southward. Thus, the Black Hills may provide a generalized location of the Paleozoic rocks north of the Mogul fault, and, if so, the right-lateral offset parallel to the trace of the Mogul is about 10 miles.

Among the subsidiary faults in the hanging wall of the Mogul fault, some parallel the Mogul in strike, some strike about $50^{\circ}$ more northward, and some follow geologic contacts. Those faults that 
parallel the Mogul offer no problem; they are undoubtedly parallel breaks. The parallel fault roughly 3,500 feet southeast of the Mogul is of interest because it is about the southern limit of the intense faulting. It dips northward, opposite to the Mogul; the right-lateral off set parallel to the trace measured on the contact between the Three $\mathrm{C}$ Member of the Abrigo and the Bolsa Quartzite is about 3,500 feet.

The faults that strike more northerly than the Mogul probably are gash faults. Displacement on these faults is small, and there is nothing about their offsets to suggest strike slip. In addition, the attitudes of these faults are about what would be expected for gash faults along a right-lateral strike-slip fault.

The faults that follow contacts commonly occur between rocks of different competency, such as the contacts of the massive upper unit of the Bolsa Quartzite. Such contacts are zones of weakness, and movement apparently occurred along many of them. Movement also probably occurred within some of the incompetent units. For example, along the northwest-striking fault that bounds part of the northern boundary of the granodiorite porphyry, the horizontal offset is about a mile, parallel to the strike of the fault. Yet this displacement apparently dies out abruptly westward as this fault intersects a small cross fault. It seems more likely that on the west side of the cross fault, the fault bends parallel to bedding, where the movement cannot be recognized. Likely sites for this particular fault are either along the contact between diabase and the upper member of the Dripping Spring Quartzite or in some shaly zone within this upper member.

Sometime after the accumulation of the American Flag Formation, but probably before movement along the Mogul fault, the mass of granodiorite porphyry in the southwest corner of the area was forcibly intruded. In a general way, the intrusion "shouldered" its way into the Cambrian rocks, pushing the rocks aside both toward the east and the west. On the west side the porphyry clearly arched or bowed the rocks toward the west. The northwest-trending fault along part of the northern contact of the porphyry is compatible with forceful intrusion. Nevertheless, the fault is parallel to the Mogul, and the offset is also right lateral. The similarity cannot be dismissed as chance, and the fault probably formed at the same time as the Mogul, that is, after the intrusion of the porphyry.

The eastward-arching of the beds along the east side of the porphyry is apparent from the distribution of the Southern Belle Member of the Abrigo. Where engulfed by the porphyry, the Southern Belle Member is segmented. The segments, which are in sec. 3, T. 11 S., R. 16 E., and in unsurveyed sec. 34, T. 10 S., R. 16 E., were not moved so far by the porphyry intrusion that the preintrusion position cannot be approximated. 
It is interesting to speculate whether the porphyry also pushed aside the section toward the north and the south from an east-west line approximately bisecting the outcrop area of porphyry. At the ends of this line the Cambrian rocks are missing on both the east and west flanks of the porphyry. As the contact effects of the porphyry reveal that it did not possess sufficient energy to assimilate the wallrocks, the missing Cambrian rocks, therefore, were either floated beyond the present level of observation, or the rocks were forcibly pried apart. If the latter, movement must have occurred as slippage along the bedding planes. A likely zone for such movement would be the base of the quartzite unit of the Bolsa. Interestingly, the siltstone unit of the Bolsa, which underlies the quartzite, ends a short distance north of the porphyry. It seems possible that the absence of the siltstone unit adjacent to the porphyry is not necessarily due to nondeposition; the siltstone could be faulted out.

The granodiorite porphyry is cut by a moderate to weak foliation that is not uniformly distributed. Local areas as much as half a mile across lack any megascopic trace of the foliation, yet in general the foliation occurs in all parts of the mass. At first glance the foliation attitudes appear to be randomly oriented, but closer study reveals that 35 percent lies in the range $\mathrm{N} .40^{\circ}-65^{\circ} \mathrm{W} ., 15^{\circ}-60^{\circ} \mathrm{SW}$, and 60 percent in the range $\mathrm{N} .5^{\circ}-65^{\circ} \mathrm{W} ., 15^{\circ}-60^{\circ} \mathrm{SW}$. This strong concentration of attitudes similar to those of the Mogul and related faults strongly implies that the same stresses were responsible for both. This coincidence is not surprising, for the only other period of deformation in the map area younger than the porphyry is the Basin and Range deformation, which is characterized by high-angle normal faults presumably resulting from tension. A distributed foliation, such as marks the porphyry, is a product of compressional forces, and therefore an unlikely product of the Basin and Range deformation.

The rocks north of the San Manuel fault reveal a structural history considerably less complete than the area south of the Mogul fault, because the Apache Group and the Paleozoic rocks are missing. 'The postEarly Cretaceous and pre-Pliocene deformation produced the thrust fault at the base of the Cloudburst Formation, probably the related high-angle reverse faults, and the intrusion of the granodiorite porphyry, rhyolite, and rhyodacite. In terms of rock units this period of deformation is younger than the Cloudburst Formation and older than the oldest sedimentary rocks deposited in basins formed during the Basin and Range deformation.

The Cloudburst Formation, which dips and faces east, is homoclinal and is soled by a thrust. In the area between the San Manuel and Mammoth faults, the outcrop elevations of the thrust and elevations exposed in the St. Anthony (Mammoth) mine establish an eastward 
dip of $5^{\circ}-10^{\circ}$. The base of the Cloudburst south of the San Manuel fault and west of the San Manuel deposit also appears to be a thrust, but the only exposure of the fault is around a small window of granitic rock, which is exposed a short distance west of the Mammoth quadrangle. Where exposed, the thrust fault is a sheared zone as much as several feet thick.

North of the San Manuel fault the separation of these older structures from those formed during the Basin and Range period is not always possible. The numerous high-angle faults in the thrust plate cannot always be related to one or the other of the two periods of deformation. On the bases of their attitude and apparent relative movement, two sets of conjugate reverse faults, one striking northeast and the other northwest, cut the thrust plate. Presumably, these reverse faults resulted from compression and are therefore related to the thrust fault. Northwest-trending normal faults also occur, and many, if not all, of these are probably part of the Basin and Range fault system.

The intrusion of the granodiorite porphyry, rhyolite, and rhyodacite, the formation of the San Manuel porphyry copper deposit, and the faulting and mineralization that formed the St. Anthony vein deposit all occurred during the post-Early Cretaceous and pre-Pliocene interval, although the two ore deposits did not form concomitantly. The St. Anthony vein system as well as other veins cut the Cloudburst Formation and the thrust at its base, whereas the San Manuel deposit and the granodiorite porphyry are older than the Cloudburst Formation. The intrusive rhyolite and rhyodacite cut the Cloudburst Formation, but their age relation to the thrust is not known.

Deformation during the Basin and Range period is largely responsible for the present physiography. The San Pedro Valley is the depressed block, and the Black Hills and Santa Catalina Mountains the elevated block. The Mammoth fault system, the San Manuel fault, probably the Turtle fault, and probably the faults that cut the Gila Conglomerate in secs. 5-9, T. 9 S., R. 16 E., are all part of this period of deformation. Older faults in this period cannot be separated from those that may be younger because faulting and accumulation of sediments in the basins occurred simultaneously. For example, in sec. 1, T. 9 S., R. 16 E., south of State Highway 77, the San Manuel fault separates the Cloudburst Formation from the indurated fanglomerate unit of the Gila Conglomerate, and the Mammoth fault separates the Cloudburst Formation from both the indurated fanglomerate unit and the unconsolidated conglomerate and sand unit. About a mile farther to the southeast, however, the unconsolidated conglomerate and sand unit of the Gila overlaps both faults where the indurated fanglomerate unit is still cut by the San Manuel fault. 
The Mammoth fault crops out from just north of Cottonwood Wash (sec. 1, T. 9 S., R. 16 E.) northwestward to within 3,000 feet of the north boundary of the area. It is an eastward-dipping high-angle normal fault. From grooves on the fault surface exposed in the St. Anthony mine, which were assumed to mark the bearing and plunge of the net slip, and from the amount of movement necessary to restore the continuity of the Mammoth and Collins veins, Creasey (1950, p. 72) concluded that the Mammoth is an oblique slip fault and that the dip-slip component was several times greater than the strike slip. The hanging wall (east side) moved down and to the northwest with respect to the footwall; the normal dip-slip component in the St. Anthony mine was computed to be about 700 feet. Steele and Rubly (1947, p. 5) state that the "vertical displacement" on the Mammoth fault (East fault of Steele and Rubly) is about 200 feet near the San Manuel deposit. The figures given by Creasey and by Steele and Rubly were derived from the movement on a single strand or fault surface. The composite displacement on the Mammoth fault system is undoubtedly larger.

The Mammoth fault is composite where it cuts the Cloudburst Formation. From about the latitude of Tiger northward, the Cloudburst Formation forms both walls of the Mammoth fault, and here the fault comprises many strands. In places, principal fault planes are difficult to determine, yet the existence and general location of the northwest-trending fault zone is quite evident. From Tiger southward to State Highway 77, the Mammoth fault comprises two strands, and from Highway 77 southward, only one. Where the fault consists of only one or two strands, one or both walls are Gila Conglomerate. This fact may signify that the Mammoth fault existed before the deposition of the Gila Conglomerate and was reactivated during or after the accumulation of the basin deposits.

The San Manuel fault crops out from the north flank of Signal Peak, which is near the western boundary of the area, east-southeastward to Smelter Wash in sec. 18, T. 9 S., R. 17 E. It exists as two separate overlapping strands in sec. 28 , T. 8 S., R. 16 E., which are not connected on the surface, and is offset by two high-angle normal faults in sec. 35, T. 8 S., R. 16 E. The fault dips southwestward at angles ranging from $25^{\circ}$ to $70^{\circ}$. In the San Manuel mine the dip averages about $25^{\circ} \mathrm{SW}$, and the average dip at the surface is estimated to be about $35^{\circ} \mathrm{SW}$; certainly, at most places the dip is less than $45^{\circ}$.

During the early exploration and development of the San Manuel deposit, the question of whether the San Manuel fault might not be a thrust was commonly raised because of its low dip. Schwartz (1953, p. 17) and Steele and Rubly (1947, p. 5) both conclude that it 
is a low-angle normal fault. Steele and Rubly attribute the low angle of dip to post-Gila tilting, which decreased the dip from about $60^{\circ}$ or $65^{\circ}$. They assume that the San Manuel fault is older than the regional tilting, an assumption which is difficult either to prove or to disprove.

Conversely, after a careful study of the structures in the San Manuel deposit, Wilson $(1957$, p. 8) concludes that the San Manuel fault is a thrust. Wilson found that the fracture pattern in the deposit, including the San Manuel fault, indicated compression and that the attitude of the San Manuel fault was compatible with other indications of compression, although it formed during the later period of regional compression.

The relative displacement of the Cloudburst Formation and of the thrust fault that soles the formation, suggest that the San Manuel is a right-lateral fault with a large strike-slip component. The unequivocal proof, however, of the absolute movement on the San Manuel fault, such as the recognition of a point on the hanging wall formerly in juxtaposition to a point on the footwall, was not found. The geologic map shows that the separation on the San Manuel fault is right lateral. It also shows that the thrust fault at the base of the Cloudburst Formation lies at a lower elevation in the hanging wall of the San Manuel fault than in the footwall, if the presence of a thrust at the base of the Cloudburst is granted. The vertical separation of the thrust at any point is not known, but a window in the thrust plate south of the San Manuel fault in the adjoining Oracle quadrangle about 2,000 feet west of sec. 31 , T. 8 S., R. 16 E., exposes the thrust at an altitude of about 3,700 feet. As pointed out elsewhere, the thrust fault in the footwall of the San Manuel fault dips $5^{\circ}-10^{\circ}$ eastward. Assuming a general eastward dip of $10^{\circ}$ for the thrust on the hanging wall of the San Manuel fault, the vertical separation of the plane of the thrust in about the central part of sec. 29, T. 8 S., R. 16 E., is about 2,000 feet, a figure probably not too small by more than 100 percent. Assuming a $45^{\circ}$ dip for the Cloudburst Formation and a strike at right angles to the San Manuel fault, a normal dip-slip movement sufficient to produce a vertical separation of 2,000 feet for the beds would produce an offset parallel to the trace of the fault of about 2,000 feet, or not more than 4,000 feet, allowing for 100 percent error in underestimation of the vertical separation. As shown on the geologic map, however, the offset (horizontal separation) parallel to the trace of the fault exceeds 10,000 feet. It seems probable, therefore, that the displacement had a dominant component of right-lateral strike-slip movement.

The similarity between the San Manuel and the Mogul faults is conspicuous: both strike northwestward, and both are thought to be 
right-lateral strike-slip faults. The chief difference seems to be that the San Manuel fault moved significantly after the deposition of the fanglomerate unit of the Gila Conglomerate, whereas the Mogul fault moved only a trifle, as indicated by a vertical separation on the base of the Gila of about 50 feet. Whether the displacement of the Gila Conglomerate on the San Manuel fault is less than the displacement of the Cloudburst Formation was not determined because of lack of information on the location of the Gila on the footwall of the San Manuel fault west of the Mammoth fault. Therefore, it cannot be established that the San Manuel fault was active during the post-Early Cretaceous and pre-Pliocene period, but neither can it be established that it was not in existence.

In the areas of the Basin and Range province where the marginal faults were not active in the Recent Epoch, the location of the faults commonly cannot be determined. In areas of degradation, pediment gravels or other surficial material on their way out of the basin effectively mask the position of the fault, and in areas of aggradation, because the faults occur at the break in slope, their trace is the first place to receive sediment. For these reasons, inactive Basin and Range faults commonly are obscure. 'The Mammoth quadrangle is no exception; the Basin and Range faults are obscure here, for there must be other major faults belonging to this period besides the Mammoth and San Manuel faults. Although the obscure faults cannot be observed directly, perhaps the pattern of the sedimentary units mapped within the Gila Conglomerate provides a clue to their location, particularly the contact between (1) the marls and siltstones and (2) the indurated fanglomerates.

On the east side of the San Pedro Valley, the contact between the marls and the fanglomerate is remarkably well defined and straight. As pointed out elsewhere, this contact results from the extremely rapid interfingering of the two rock types. The marls and siltstones are lake deposits, and the fanglomerates are fluviatile. This means that streams carrying large boulders discharged into a lake whose shoreline conditions were such that interfingering of the two types of sediments was held to a narrow zone; this zone itself was virtually linear. Presumably, one of the conditions was deep water close to the shoreline. Such a shoreline might be controlled by a normal fault-a fault that was active during sedimentation. It seems that some such explanation is necessary to explain the remarkable relations of these two rocks.

On the west side of the valley, a similar relation exists in the southern part of the quadrangle. The contact between fanglomerate and marls is on the strike extension of the Mammoth and San Manuel faults, both of which are part of the Basin and Range fault system. Therefore, this contact may reflect a buried Basin and Range fault. 


\section{PEDIMENTS}

The San Pedro River is part of an integrated drainage that flows to the Pacific Ocean successively through the San Pedro, Gila, and Colorado Rivers, and erosional surfaces (pediments) cut on the Gila Conglomerate dominate the physical features of the map area, plate 1. Two levels of pediments mark relatively stable periods during degradation. There is a direct correlation between the extent to which the pediments developed and the bedrock on which they were cut. This is strikingly displayed east of the San Pedro River where extensive remnants of a pediment cover the marls and silts, all of which terminate at or near the contact with the indurated fanglomerate. The pediments cut on the soft marls and silts have slopes of about 150 feet per mile, with the exception of those at the north margin of the quadrangle east of the San Pedro River, which for unknown reasons are significantly steeper. Pediment remnants, cut on indurated fanglomerate, occur only west of the San Pedro, plate 1 . These have consistent slopes of about 200 feet per mile.

Profiles drawn west of the San Pedro in the southern part of the quadrangle suggest two levels of pediments. The lower pediment is cut almost exclusively on the marls and silts, but locally it extends as much as 2,000 feet over the contiguous conglomerates. However, the lower pediment probably never developed significantly on the indurated fanglomerates because no scattered remants were recognized. The upper level, which by projection at the slope of 200 feet per mile would pass at 100-200 feet over the top of the lower, is found only on the indurated fanglomerate, and except for three small patches along the eastern border of the quadrangle, is only west of the San Pedro River.

There is some question of whether only one pediment existed, and that with an appreciably steeper slope on the conglomerate than on marls and silts. The small pediment remnant in sec. 28, T. 10 S., R. $17 \mathrm{E}$., helps to negate this concept. Between this remnant and those to the west, the slope of the pediment projects at about 200 feet per mile, in accord with the slopes of the upper surface of the pediment remnants themselves. To join, however, the remnant in sec. 28 with the lower pediment cut on the marls and silts only 4,000 feet away, the slope would have to increase to 300 feet per mile and abruptly flatten to 150 feet per mile at the junction. This single pediment theory, however, seems highly unlikely.

Apparently, pediments are extensive along the San Pedro Valley. Bryan (1926) described briefly an upper and a lower pediment surface in the vicinity of Benson and named them the Tombstone and Whetstone surfaces, respectively. He mentioned that the Tombstone sur- 
face sloped at 50-200 feet per mile, which embraces the range of slopes found in the Mammoth quadrangle. Whether the two pediments in the Mammoth quadrangle correlate with Bryan's Tombstone and Whetstone surfaces is not known, but the possibility exists.

The gently dipping smooth surface in the central part of the map area south of Smelter Wash represents a slightly dissected surface of the lower pediment. On the geologic map this is not mapped as Quaternary pediment gravels, but it was concluded only after carefu] study that the gravels had been largely stripped. This conclusion was based on remnants of pediment gravels being restricted to some of the highest parts of the interfluves. The general surface, therefore, seems to have been lowered by about $15-20$ feet.

A remarkably level surface was developed on the granitic rocks during a period that may predate the deposition of the Gila Conglomerate. One such surface is north of the Mogul fault, and another, which is especially smooth, is the area north of the San Manuel fault and west of the thrust at the base of the Cloudburst Formation.

No special effort was made to determine the origin of these surfaces. They are obviously being dissected during the present erosion cycle, and they are obviously well below the level of the upper pediment. Slopes are about 150 feet per mile, essentially like those on the lower pediment surfaces, and it is possible that they should be correlated with the lower pediment. However, the relief on the contact between the Gila Conglomerate and the granitic rocks north of the Mogul fault is remarkably low. This indicates that here the Gila accumulated on a surface of virtually no relief; it is therefore possible that the present surface is an exhumed erosional surface that predates the Gila Conglomerate.

\section{MINES}

The major mines in the Mammoth quadrangle are the San Manuel mine, which produces copper, and the St. Anthony (Mammoth) mine, which produced gold, vanadium, and molybdenum from oxidized ores, and lead and zine from unoxidized ore. Lesser mines are of two general types: gold and tungsten. These include the Southern Belle gold mine and the Maudina and Morning Star tungsten mines. In addition, there is a base-metal prospect herein named for its owner, Mary West. Included in this section on mines are short summaries of the San Manuel and St. Anthony mines, brief descriptions of the Southern Belle gold mine and the Mary West prospect, and a more complete description of the Maudina and Morning Star tungsten mines, largely abstracted from a report by Bateman and Erickson (1944). 
The San Manuel mine, the only active one in the quadrangle when fieldwork was finished, is the subject of two Geological Survey reports (Schwartz, 1953; Creasey, 1965) ; data on the mine, therefore, are summarized here only briefly. The St. Anthony mine (also called Mammoth) is inaccessible, and no additional subsurface data subsequent to Creasey's (1950) report are available. The outcrop of the Mammoth and Collins veins is described in Creasey's (1965) report on the San Manuel deposit.

\section{AGE OF THE ORE DEPOSITS}

The San Manuel deposit formed after intrusion of the granodiorite porphyry and before accumulation of the Cloudburst Formation. These age relations are established by the presence of mineralized boulders of granodiorite porphyry in fanglomerate beds in the Cloudburst. The lead-alpha age of zircons from the granodiorite porphyry is $97-130$ million years (p. 47), and stratigraphic correlations indicate that the Cloudburst Formation is Late (?) Cretaceous or early Tertiary, (p. 55). These data restrict the age of the San Manuel deposit to Cretaceous or early Tertiary.

The St. Anthony (Mammoth) deposit is younger than the Cloudburst Formation, and older than the Mammoth fault, which probably originated during the Basin and Range period of deformation. The age of the deposit therefore is early to middle Tertiary.

The tungsten deposits are younger than the Escabrosa Limestone and the Mogul fault, but their age cannot be restricted further from geologic relations. Geologic intuition suggests they are younger than the granodiorite porphyry that is about a mile south of the deposits. This mass of granodiorite porphyry cuts the Cretaceous(?) American Flag Formation.

The age and origin of the gold-bearing quartz veins in the Southern Belle mine is conjectural. Because the quartz veins are offset by shears thought to be related to the Mogul fault, the mineralization could be older than the tungsten mineralization in the adjacent mines, which is younger than the Mogul fault. There is nothing, however, to refute essentially contemporaneous mineralization and faulting.

\section{ST. ANTHONY (MAMMOTH) MINE}

The St. Anthony (Mammoth) mine is in the west-central part of sec. 26 , T. 8 S., R. 16 E. It closed in 1952 , and the town of Tiger, which was built around the mining enterprise, was abandoned (pl. 1). Little remains except a headframe over the Mohawk shaft and a few scattered buildings. 
The deposit, described by Peterson (1938) and Creasey (1950) consists of a vein that strikes northwest, dips south, and transects quartz monzonite, the Cloudburst Formation, and intrusive rhyolite (pl. 1). The vein is cut into two segments by the Mammoth fault, which strikes northward and is downthrown on the east. The eastern segment is called the Mammoth vein, and the western segment, the Collins vein.

The oxidized parts of the veins contain gold-silver-vanadinitewulfenite ores, whereas the unoxidized part of the Collins vein contains lead-zinc ores. Oxidation extends throughout the Mammoth vein, from the surface to where the vein intersects the Mammoth fault, at a depth of about 850-900 feet below the surface. The Collins vein, however, is oxidized only to a depth of 600-700 feet and, to account for the difference, it seems probable that the vein was faulted after deep oxidation. In addition, the oxidized ores contain descloizite and mottramite in commercial amounts. The oxidation alone probably does not account for the enrichment in precious metals and relative impoverishment in base metals in the higher part of the vein; the vein must be zoned also.

The Collins vein below the 700 level consisted of unoxidized galena, sphalerite, chalcopyrite and minor pyrite in a gangue of quartz, chlorite, specularite, barite, and fluorite. Below the 1,000 level, galena and sphalerite decreased and pyrite and chalcopyrite seemed to increase. Both changes are due to primary mineral zoning.

The approximate total production from 1881 to 1947 consists of $1,889,375$ tons of ore which yielded 397,201 ounces of gold, 983,918 ounces of silver, $3,456,121$ pounds of copper, $74,730,289$ pounds of lead, $48,272,654$ pounds of zinc, $6,314,822$ pounds of $\mathrm{MoO}_{3}$, and 2,540,842 pounds of $\mathrm{V}_{2} \mathrm{O}_{5}$.

\section{SAN MANUEL DEPOSIT}

The San Manuel porphyry copper deposit is in secs. 34 and 35, $\mathbf{T}$. 8 S., R. 16 E., and secs. 2 and 3, T. 9 S., R. 16 E. The altered zone that contains the ore body is about $8,000-9,000$ feet wide and 9,300 feet long; the long dimension of the ore body itself trends about $\mathrm{N}$. $80 \mathrm{E}$. Before mining, the deposits were estimated to contain about 500 million tons of combined sulfide and oxide ore that averaged about 0.8 percent copper.

The ore occurs in quartz monzonite, granodiorite porphyry, and diabase. In general, the ore body lies along the steeply dipping contact of granodiorite porphyry (above) and quartz monzonite (below) ; the granodiorite porphyry, however, is the most abundant host rock.

The primary sulfide minerals are chalcopyrite, pyrite, and molybdenite. Chalcocite is supergene; it is restricted to the lower part of the 236-465 $0-67-7$ 
oxidized zone where it is accompanied by chryscolla and residual sulfides. Silicate alteration that accompanied the copper mineralization produced quartz, K-feldspar, biotite, and muscovite (sericite). In addition, the ore contains residual albite, chromite, rutile, apatite, and kaolinite. Alteration peripheral to the ore body crystallized quartz, muscovite (sericite), pyrite, and kaolinite, and destroyed all the primary silicate minerals other than the quartz.

In the ore body, sulfides occur disseminated and in veinlets. Quartzchalcopyrite-pyrite veinlets are abundant, and quartz-molybdenite or molybdenite veinlets are common but not abundant. A few veinlets of quartz-K-feldspar were recognized during mine mapping and petrographic study of the ores.

\section{SOUTHERN BELLE MINE}

The Southern Belle (fig. 7) is a lode gold deposit located in unsurveyed secs. 19 and 20, T. 10 S., R. 16 E. No records of the production or description of the property could be found, and the mine was inaccessible. The present surface indications consist of many prospect pits and short adits, several long adits (judging by the size of the dumps), and several shafts, some of which probably were for ventilation. None of the larger workings are now accessible.

All but a few of the workings are on the south side of an easttrending ridge that is composed chiefly of the upper member of the Dripping Spring Quartzite (fig. 7). All the workings show that the quartzite was brecciated and sheared intensely. Most shear planes strike northwest, but many strike northeast. Dips range from nearly flat to steep. Quartz veins as much as 2 feet thick are common; most seem to dip at low angles, which make the strikes erratic and difficult to determine. Most of the veins are offset by high-angle shears.

Two days were spent examining the surface outcrops, trying to determine any consistent pattern of the deposit, figure 7 . The rocks are so intensely deformed that geologic continuity from one outcrop to another is most difficult to establish. The crest of the ridge appears to be a white relatively thick-bedded massive quartzite, quite unlike any other quartzite in the upper member of the Dripping Spring elsewhere. It was like the quartzites in the middle member, but it is overlain by the siltstone unit of the Bolsa, and is therefore thought to be part of the upper member. Because the contact between the Dripping Spring and the Bolsa Quartzites is an erosional unconformity, beds at the surface in one area might be missing through erosion in another. Hence, the unusual quartzite near the Southern Belle mine is reasonable. Fine-grained thin-bedded quartzites with shale partings underlie these massive quartzites. The contact between the two is flatter 


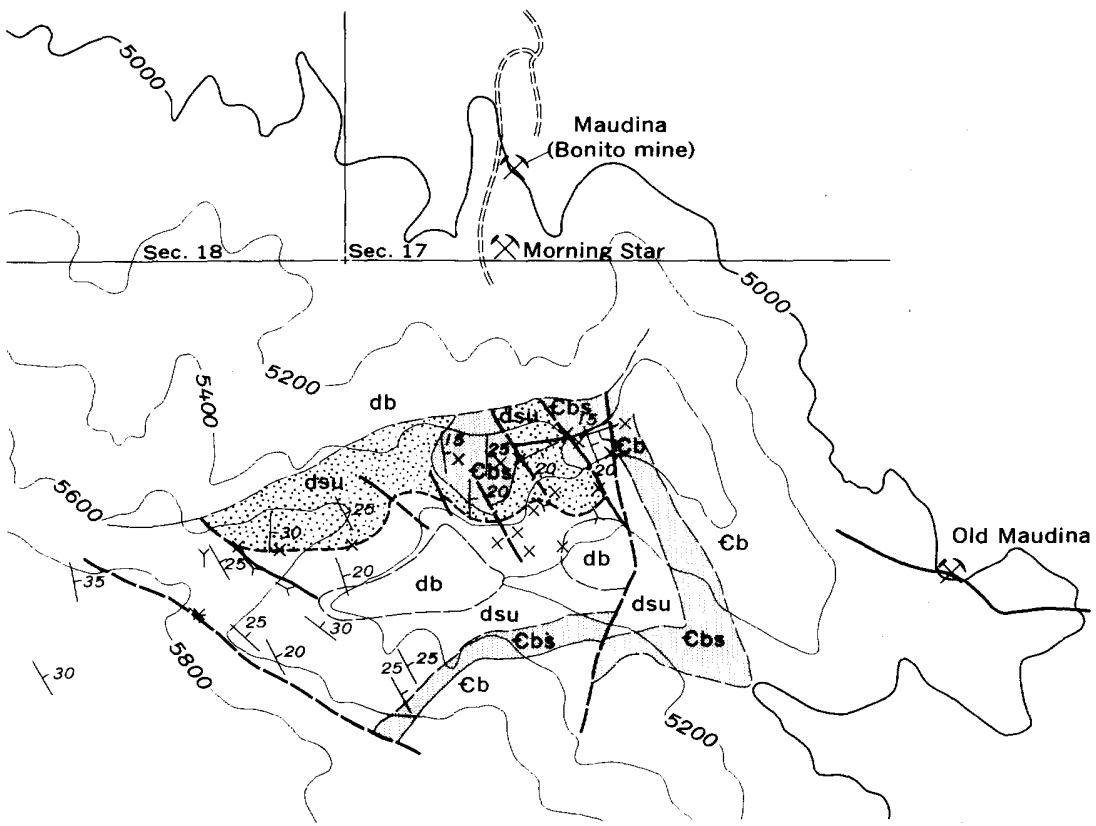

N

0

CONTOUR INTERVAL 200 FEET

$1 / 2$ MILE

\section{EXPLANATION}

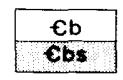

Bolsa Quartzite

$\mathrm{Cb}$, thick-bedded to massive quartzite €bs, maroon siltstone

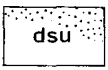

Dripping Spring Quartzite, upper member Massive thick-bedded white quartzite where stippled; thin-bedded fine-grained quartzite separated by shale partings where not stippled

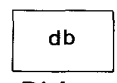

Diabase

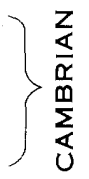

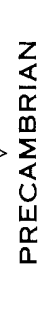

\section{Dashed where approximately located}

Fault

Dashed where approximately located

Top of sheared zone

Mineralized with gold-bearing quartz veins

$$
\begin{aligned}
& \frac{25}{1-1} \\
& \text { Strike and dip of beds } \\
& \text { Prospect pit or shallow shaft } \\
& \times
\end{aligned}
$$

FIGURE 7.-Geologic sketch map of the area around the Southern Belle gold mine.

than the bedding in either quartzite and is the zone that contains the quartz veins and the majority of the mine workings. It appears to be a sporadically mineralized sheared zone, but the displacement on it is insufficient to bring into juxtaposition rocks other than the upper member of the Dripping Spring Quartzite. 


\section{MARY WEST PROSPECT}

The Mary West prospect is located in one of the tributary canyons to Peppersauce Canyon south of the Mogul fault. It is about $41 / 2$ miles north of the southern boundary of the quadrangle and 1 mile east of the west boundary.

The surface expression of the mine consists of an inclined shaft driven on a quartz vein along the contact between the upper and lower members of the Pioneer Formation. Exposures of the quartz vein at the surface extend only a few feet from the shaft. A few specimens containing galena and pyrite were found on the dump.

Quartz veins occur at several places along the contact between the two members of the Pioneer Formation. This contact separates the massive thick-bedded quartzites of the lower member from the thinbedded slates of the upper member; and because it separates rocks of such different physical properties, it is commonly marked by fractures and possibly by faults. The quartz veins along the contact probably are due to the increased permeability resulting from the movement along the contact.

\section{TUNGSTEN MINES}

\section{GENERAL FEATURES}

The tungsten mines are in the northern part of the Santa Catalina Mountains in the SW $1 / 4$ sec. 17 and the NW1/4 sec. 20, T. 10 S., R. 16 E. On the map the names of the mines are shown as the Bonito mine and the Old Maudina mine, but these names have not been used consistently and herein the names Maudina and Morning Star mines are used. The Maudia mine comprises three widely separated workings: the Cody tunnel, the Pure Gold workings, and the Old Maudina mine. The Pure Gold workings and the Morning Star mine, however, are only about 240 feet apart and are collectively grouped under the name Bonito mine on the topographic map, which shows two symbols for mines. The northem symbol represents the Pure Gold workings, and the southern one, the Morning Star mine. The Old Maudina mine is about 3,500 feet southeast of the other workings. The Cody tunnel is the southern adit of the two shown on the ridge east of the Pure Gold and Morning Star workings (pl. 1).

The Maudina and Morning Star mines are described by Wilson (1941), Bateman and Erickson (1944), and Dale (1959). Wilson gives a brief account of the geologic setting, development work, and ore bodies in the Old Maudina and Morning Star mines; but his report predates the extensive development during World War II, which includes the Pure Gold workings. Bateman and Erickson give the most complete account of the geology of the Pure Gold workings and the Morning Star mine; but their report contains nothing on the Old 
Maudina, which was inactive at the time of their investigation. Most of the geologic data on the mines have been abstracted from Bateman and Erickson. Dale's report records the total mine development, history, and production to 1958 , but it depends heavily on Wilson and on Bateman and Erickson for descriptions of rocks, structures, and ore bodies.

\section{GEOLOGY}

The principal geologic feature of the area is the Mogul fault, which is described elsewhere in this report. In this area the fault dips $30^{\circ}-60^{\circ} \mathrm{S}$. It comprises many planes of movement and consists of a zone of breccia and mylonite as much as 50 feet thick. All the mineralized zones are confined to a fault block of Escabrosa Limestone adjacent to the Mogul fault. The fault block is bounded on the west and northwest by the Abrigo Formation, on the south by quartzites of the Pioneer Formation, on the east by the Dripping Spring Quartzite, and on the north by Precambrian quartz monzonite (Oracle Granite of Peterson, 1938) of plate 2. Bedding in the Escabrosa is generally absent or unrecognizable, but on the ridge above the Pure Gold workings, the bedding appears to strike N. $20^{\circ} \mathrm{W}$., and to dip $75^{\circ} \mathrm{E}$.

The scheelite is restricted to well-defined shoots in silicified Escabrosa Limestone. The silicification is an alteration and is restricted to zones in the limestone that seem to be controlled by faults or fractures related to the Mogul fault. The Escabrosa Limestone adjacent to the silicified zones has recrystallized to marble.

\section{MAUDINA MINE}

The Maudina mine (pl. 2) comprises 29 patented claims and workings centered around the Pure Gold workings, the Cody tunnel, and the Old Maudina mine. The Pure Gold workings consist of a 175-foot adit, an opencut 30 by 160 feet, an inclined shaft 35 feet deep, and adit 88 feet long, and two shallow shafts (Dale, 1959, p. 52). The workings in the Cody tunnel total 1,165 feet: 830 feet of tunnel and 335 feet of crosscuts (Dale, 1959, p. 52). The workings of the Old Maudina mine consist of a 175-foot vertical shaft and levels at 50,100,150, and 175 feet below the collar of the shaft. The levels comprise about 1,000 feet of crosscuts and drifts (Dale, 1959, p. 52; Bromfield, 1950).

The ore body in the Pure Gold workings is localized in the silicified upper part of the breccia in the Mogul fault (fig. 9). The surface width of the zone ranges from 5 to 40 feet, and the exposed length in 1943 was about 200 feet. The mineralized zone appears to dip paralle] to the fault, about $40^{\circ}-50^{\circ}$ southward. 
In 1943 the adit was only 120 feet long and barely reached the downward extension of the mineralized zone 50 feet below the level of the opencut. The ore in the face contained only a trace of scheelite. Two samples by B. R. Frisbie, of the Reconstruction Finance Corp., assayed 0.14 and 0.05 percent $\mathrm{WO}_{3}$. Bateman and Erickson thought that better grade ore might lie beyond the face, but whether or not this preaiction proved correct is not known.

The ore shoot in the Old Maudina mine is along a steep-dipping fault $\left(\mathrm{N} .80^{\circ}\right.$ W.) that is about parallel to the Mogul fault. The ore shoot plunges $45^{\circ} \mathrm{E}$., ranges in width from 4 to 15 feet, and is 50 feet or more in siope length (Wilson, 1941, p. 32). The ore consists of veinlets and replacement masses of scheelite, commonly free of gangue but locally in a quartz gangue. The best ore was reported to be below the 100-foot level in impure limestone beneath sandstone and quartzite (Wilson, 1941, p. 33). Lead carbonate and wulfenite are reported from the upper 50 feet of the ore shoot. Wilson $(1941$, p. 33) describes a small separate ore shoot, 20 by 12 by 4 feet, on the 150 -foot level north of the main ore shoot and suggests further exploration along the fault.

\section{MORNING STAR MINE}

The Morning Star mine lies south of the Pure Gold workings, the two properties sharing a common boundary (pl. 2). In 1944 the ore came from a glory hole and some small stopes west of the glory hole. The scheelite was in an irregular body of silicified limestone, elongated in a northwest-southeast direction. The scheelite was concentrated in large crystals along two faults at right angles to each other that cut through the silicified limestone. The northwest-trending fault, which has some postmineral movement, offset the southwest-trending fault about 10 feet. The ore along the faults, across widths of 6 inches to 2 feet, appeared under ultraviolet light to contain several percent $\mathrm{WO}_{3}$. Scheelite was sparsely disseminated throughout the rest of the silicified zone.

The silicified limestone breccia, 5 feet wide, near the portal of the lower adit, which is probably a continuation of the Pure Gold ore zone, contains substantial amounts of fine-grained scheelite. The first 60 feet of the adit is also dug in silicified limestone, but it contains little scheelite. 


\section{PRODUCTION}

Both the Morning Star and the Maudina mine (Pure Gold workings) were active during World War II, when the demand for tungsten was high. After the war the demand for tungsten dropped, the price fell, and the mines closed. So far as known, there has been only small production since 1944 and no successful attempt to reactivate the mines. D. M. Lemmon, of the U.S. Geological Survey, supplied the following production records:

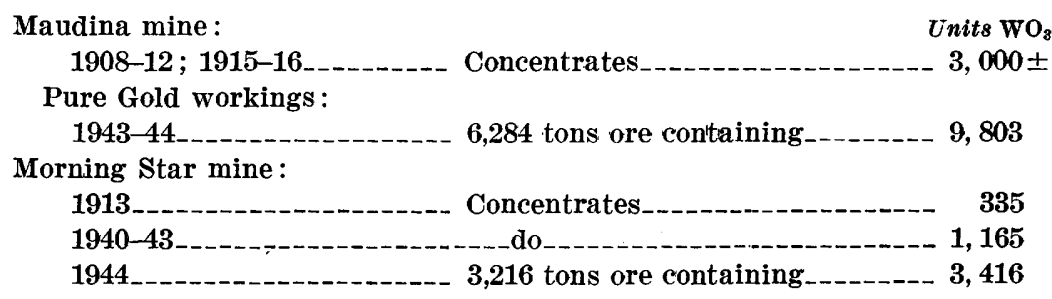

Dale $(1959$, p. 52,61$)$ reports the total production of the Maudina mine as 15,000 short-ton units of $\mathrm{WO}_{3}$, and that of the Morning Star mine as exceeding 6,000 units.

\section{RECOMMENDATIONS}

The zone south of the Mogul fault for perhaps one or two thousand feet where Paleozoic carbonate rocks are cut by the Mogul or related faults offers good opportunities for prospecting. In view of the tungsten distribution in the Morning Star mine and Pure Gold workings, the Escabrosa Limestone appears to be the most favorable host rock, but other carbonate units should be prospected also.

Most likely the mineralizing solutions originated from some "relative" of the granodiorite porphyry that crystalized at some depth within the crust. The Mogul and related faults served to guide the mineralizing fluids to the carbonate host rocks. The Mogul is a strong fault and undoubtedly penetrates the earth's crust to considerable depths. 


\section{REFERENCES CITED}

Banerjee, A. K., 1957, Petrology and structure of the Oracle granite, Pinal County, Arizona : Arizona Univ., Tucson, Ph.D. thesis, 155 p.

Bateman, P. C., and Erickson, M. P., 1944, Maudina and Morning Star tungsten mines, Pinal County, Arizona : U.S. Geol. Survey open-file map, July 7, 1944, 2 maps with text.

Blake, W. P., 1908, Note upon the structure of the Santa Catalina gneiss, Arizona : Science, new ser., v. 28, p. 379-380.

Bromfield, C. S., 1950, Geology of the Maudina mine area, northern Santa Catalina Mountains, Pinal County, Arizona: Arizona Univ., Tucson, M.S. thesis.

Bryan, Kirk, 1926, San Pedro Valley, Arizona, and the geographic cycle [abs.] : Geol. Soc. America Bull., v. 37, no. 1, p. 169-170.

Chew, R. T., III, 1952, Mid-Tertiary rock unit from southern Arizona [abs.] : Geol. Soc. America Bull., v. 63, no. 12, pt. 2, p. 1324.

Cooper, J. R., 1960, Some geologic features of the Pima mining district, Pima County, Arizona: U.S. Geol. Survey Bull. 1112-C, p. 63-103.

Cooper, J. R., and Silver, L. T., 1964, Geology and ore deposits of the Dragoon quadrangle, Arizona : U.S. Geol. Survey Prof. Paper 416, 196 p.

Creasey, S. C., 1950, Geology of the St. Anthony (Mammoth) area, Pinal County, Arizona, chap. 6 in pt. 1 of Arizona zinc and lead deposits: Arizona Bur. Mines Bull. 156, Geol. Ser. 18, p. 63-84.

Creasey, S. C., 1965, Geology of the San Manuel area, Pinal County, Arizona, with a section on the San Manuel ore deposits, by J. D. Pelletier and S. C. Creasey : U.S. Geol. Survey Prof. Paper 471, 64 p.

Creasey, S. C., and Kistler, R. W., 1962, Age of some copper-bearing porphyries and other igneous rocks in southwestern Arizona, in Short papers in geology, hydrology, and topography : U.S. Geol. Survey Prof. Paper 450-D, p. D1-D5.

Dale, V. B., 1959, Tungsten deposits of Yuma, Maricopa, Pinal, and Graham Counties, Arizona : U.S. Bur. Mines Rept. Inv. 5516, 68 p.

Gilbert, G. K., 1875, Report on the geology of portions of New Mexico and Arizona: U.S. Geog. and Geol. Survey West 100th Meridian (Wheeler), v. 3, pt. 5, p. 503-567.

Giletti, B. J., and Damon, P. E., 1961, Rubidium-strontium ages of some basement rocks from Arizona and northwestern Mexico: Geol. Soc. America Bull., v. 72, no. 4, p. 639-644.

Gilluly, James, 1956, General geology of central Cochise County, Arizona: U.S. Geol. Survey Prof. Paper 281, 169 p.

Goddard, E. N., chm., and others, 1948, Rock-color chart: Washington, Natl. Research Council ; repub. by Geol. Soc. America, 1951, $6 \mathrm{p}$.

Granger, H. C., and Raup, R. B., 1964, Stratigraphy of the Dripping Spring Quartzite, southeastern Arizona: U.S. Geol. Survey Bull. 1168, 119 p.

Heindl, L. A., 1963, Cenozoic geology in the Mammoth area, Pinal County, Arizona : U.S. Geol. Survey Bull. 1141-E, 41 p.

Hess, H. H., 1949, Chemical composition and optical properties of common clinopyroxene, Pt. 1: Am. Mineralogist, v. 34, nos. 9-10, p. 621-666; abs. v. 33, nos. 3-4, p. 199.

Krieger, M. H., 1961, Troy quartzite (younger Precambrian) and Bolsa and Abrigo Formations (Cambrian), Northern Galiuro Mountains, southeastern Arizona, in Short papers in the geologic and hydrologic sciences: U.S. Geol. Survey Prof. Paper 424-C, p. C160-C164. 
McKee, E. D., 1951, Sedimentary basins of Arizona and adjoining areas: Geol. Soc. America Bull., v. 62, no. 5, p. 481-505.

Nockolds, S. R., 1954, Average chemical compositions of some igneous rocks: Geol. Soc. America Bull., v. 65, no. 10, p. 1007-1032.

Pelletier, J. D., 1957, Geology of the San Manuel mine, Arizona : Mining Eng., v. 9 , no. 7 , p. 760-762.

Peterson, N. P., 1938, Geology and ore deposits of the Mammoth mining camp area, Pinal County, Arizona: Arizona Bur. Mines Bull. 144, Geol. Ser. 11, $63 \mathrm{p}$.

Priser, John, 1948, Operation underground [Catalina Mountain cave, Arizona] : Desert Mag., v. 11, no. 4, p. 4-7.

Ransome, F. L., 1903, Geology of the Globe copper district, Arizona: U.S. Geol. Survey Prof. Paper 12, $168 \mathrm{p}$.

1904, Geclogy and ore deposits of the Bisbee quadrangle, Arizona: U.S. Geol. Survey Prof. Paper 21, 168 p.

Ransome, F. L., 1915, The Paleozoic section of the Ray quadrangle, Arizona: Washington Acad. Sci. Jour., v. 5, p. 380-388.

Ross, C. P., 1925, Ore deposits of the Saddle Mountain and Banner mining districts, Arizona : U.S. Geol. Survey Bull. 771, 72 p.

Schwartz, G. M., 1953, Geology of the San Manuel copper deposit, Arizona : U.S. Geol. Survey Prof. Paper 256, 63 p.

Silver, L. T., 1960, Age determinations on Precambrian diabase differentiates in the Sierra Ancha, Gila County, Arizona [abs.] : Geol. Soc. America Bull., v. 71 , no. 12 , pt. 2 , p. $1973-1974$.

Simons, F. S., 1964, Geology of the Klondyke quadrangle, Graham and Pinal Counties, Arizona : U.S. Geol. Survey Prof. Paper 461, 173 p.

Steele, H. J., and Rubly, G. R., 1947, San Manuel [copper] prospect [Arizona] : Am. Inst. Mining Metall. Eng. Tech. Pub. 2255, Mining Technology, v. 11, no. $5,12 \mathrm{p}$.

Stoyanow, A. A., 1936, Correlation of Arizona Paleozoic formations: Geol. Soc. America Bull., v. 47, no. 4, p. 459-540.

Teichert, Curt, and Schopf, J. M., 1958, A Middle or Lower Devonian psilophyte flora from central Arizona and its paleogeographic significance: Jour. Geology, v. 66, p. 208-217.

Willden, Ronald, 1964, Geology of the Christmas quadrangle, Gila and Pinal Counties, Arizona: U.S. Geol. Survey Bull. 1161-E, p. E1-E64.

Wilson, E. D., 1941, Tungsten deposits of Arizona : Arizona Bur. Mines Bull. 148, Geol. Ser. 14, $54 \mathrm{p}$.

Wilson, E. D., 1957, Geologic factors related to block caving at San Manuel copper mine, Pinal County, Arizona: U.S. Bur. Mines Rept. Inv. 5336, 78 p. 



\section{INDEX}

[Italic page numbers indicate major references]

A.

Abrigo Formation discon formity between Martin Formetior

Peppersauce Member. alteration by contact metamorphism. minerals. stratigraphic section in Nugget Canyon Southern Belle Member $27,29,72$

Three C Member. stratigraphic section in Nugget Canyon.

Abrigo Limestone

Accessibility

Acknowledgments

Alaskite.

age

minerals.

Alluvium, Quaternary

American Flag Formation.

joints

minerals.

stratigraphic section in Nugget Canyon...

Analyses, granodiorite porphyry

Andesite dikes, age.

Apache Group. $12,14,63,64,67,69,70$

Mescal Limestone Aplite .$$
\text { age. }
$$

dikes...

$$
\text { minerals }
$$

Aplite dikes, quartz monzonite.

\section{B}

Barlow, S. R., analyst

Barnes Conglomerate Member of Drippin Spring Quartzite $10,15,19$ disconformity between Pioneer Formation.

Barnes Peak on -

Basin and Range, deformation $58,60,68,73,74,80$ faults

Bisbee Group ................................. 67

Black Hills................................ 71, 74

Bolsa Quartzite_..................... 19,22,24, 72, 73 disconformity between Dripping Spring Quartzite $19,23,82$ maroon siltstone...................... 24 stratigraphic section in Nugget Canyon... unconformity between Troy Quartzite.... 67,69

Bonito mine.

Botts, S. D., analyst

Bromfield, C. S., cited

Bryan, Kirk, cited
C

Page

Cambrian System

Campo Bonito mine... 71

Chemical and normative composition, intrusive rhyodacite.................. $\quad 67$ intrusive rhyolite.......................... $\quad 67$

Chew, R. T., cited........................... 60

Chloe, G., analyst............................ 47

Christmas....................................... 55

Christmas quadrangle........................ 14

Cloudburst Formation...........47, 49, 70, 74, 76,76

age. -

fanglomerate...................... $50,52,65,56$ monolithologic sedimentary breccias...... $\quad 62$ thrust fault............................... 73

thrust plate............................ $\quad 7,8$

volcanic rocks........................... 68

Cloudburst Wash. . ...................... 49, 52, 53

Cody tunnel..................................... 84, 85

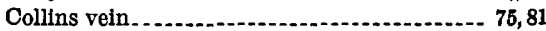

Copper Creek. . ............... 6, 48

Copper Creek Canyon...................... 62

Copper Creek granodiorite...................... 48

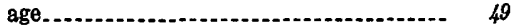

Cottonwood Wash............................ 50

Creasey, S. C., cited................ 49, 55, 64, 68, 75

Cretaceous(?) System........................ 41,48

D

Damon, P. E., cited....................... 10

Devonian System. .......................... $\$ 4$

Diabase, age.................... 12

stratiform ............ $\$ 8$

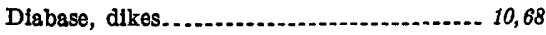

Intrusives................................ 69

minerals................................... 11

sills............................................ 10

Dike, Intrusi ve breccia. . . ....................... 56

Dikes, andesite, age...................... 68

aplite............................... 10,12,19,68

aplitic $\ldots$

diabase........................................ 10,68

diabasic...................................... 8

pebble........................................ 63

sandstone. . . .............................. 58,63

Disconformity between, Barnes Conglomerate

Member of Dripping Spring

Quartzlte and Ploneer Formation. 19

Dripping Spring and Bolsa Quartzites. 19,23,82

Martin and Abrigo Formations.......... 34, 70

Dos Cabezas.................................... 68

Dragoon Mountains............................. 68

Drlpping Spring Mountains................. 18 


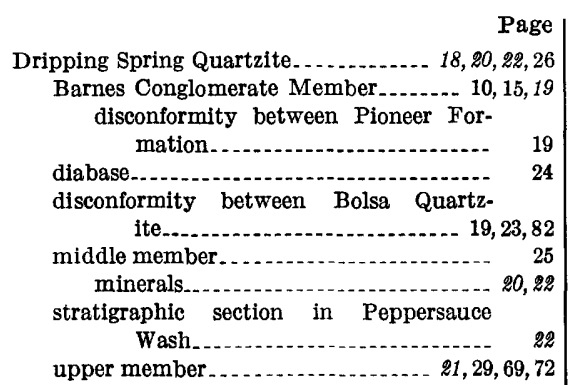

$\mathbf{E}$

Elbert Formation

Elmore, P. L. D., analyst.

Escabrosa Limestone.

fault block

inlier.

limestone caves

minerals.

$\mathbf{F}$

Fanglomerate in Cloudburst Formation.

$50,52,55,56$

Fault block of Escabrosa Limestone......... $\quad 85$

Faults:

along contacts.

Basin and Range.

high-angle normal

Mammoth.

$45,47,51,68,73,74,75$

Mogul $70,71,76,85,87$ associated and subsidiary faults.....- 71

San Manuel. ............. 45, 47, 51, 68, 73, 74,75

San Xavier thrust.

Turtle.

Fieldwork

Flood plain, San Pedro River.

Flow breccias.

Fossil rhinoceros

Fractures

Frisble, B. R., analyst.

\section{G}

Galiuro Mountains $23,50,58$

Galiuro Volcanics

age.

minerals.

unconformity between, Gila Conglomerate

Glory Hole Volcanics.

$48,49,58$

Gash faults.

Geology of tungsten mines.

Gila Conglomerate

$8,43,55,58,60,74,75,77,79$

from the indurated fanglomerate unit.... sedimentary breccias unconformity between Galiuro Volcanies.

Gila Group

Gila River

Gila Valley

Gilbert, G. K., cited

Giletti, B. J., cited.

Gilluly, James, cited

Glory Hole (or Globe) mine
Glory Hole Volcanics........................ 48

minerals............................... 48

unconformity between Galiuro Volcanics. .

Granger, H. C., cited................ 19

Granite ......................... 66

Granodiorite .................... 7,18

age

minerals.................................... 8

Granodiorite porphyry .................. 12, $23,33,34,41,42,45,68,73,87$

age..................................... 47

analyses................................. 47

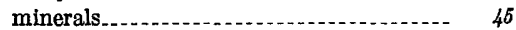

San Manuel deposit...................... 41

Gravels, quaternary .................... 64

\section{H}

Heindl, L. A., cited . . . . . . . . . . . . . . . . 60,61

Hess, H. H., cited ............................ 54

Holy Joe Peak quadrangle.................. 19, 23

Horse Mountain Volcanics. .................. 57

\section{I}

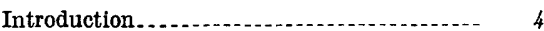

Intrusive rhyodacite....................... $\quad 55$

age

chemical and normative composition..... $\quad 57$

Intrusive rhyolite . . . .

age

chemical and normative composition ..... $\quad 57$

minerals. 56

\section{$\mathbf{J}$}

Jaffe, H. W., cited............. 55

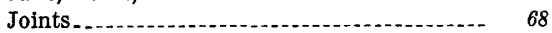

American Flag Formation............. 42

Kistler, R. W., cited...

Klondyke quadrangle . . . . . . . . . . $48,49,57,59$

Krieger, M. H., cited.................... 19, 23

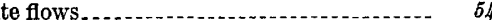

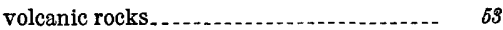

Lemmon, D. M., cited...................... 87

Limestone caves, Escabrosa Limestone.......

Location. . . .

\section{M}

McKee, E. D., cited

Mammoth fault.......... 45, 47, 51, 68, 73, 74, 75, 77, 81

Mammoth fault system......... 74

Mammoth mining camp

Mammoth vein............. 75,81

Maroon siltstone, Bolsa Quartzite.........-..- 24

Maroon slates, Pioneer Formation.......... 24

Martin Formation .................... $\$ 4, \$ 7,64,70$ disconformity between Abrigo Formation - 34,70 stratigraphic section in Nugget Canyon-- $\quad 36$

Martin Limestone. . .

Mary West base-metal prospect.............. 84

Maudina mine.............................. 84

Maudina tungsten mine....................... 85

Mescal Limestone of Apache Group. ....... 18 
Page

laskite.

American Flag Formation.

aplite.

diabase dikes.

Dripping Spring Quartzite, middle member.

Escabrosa Limestone

Galiuro Volcanics $-n_{-}$

Glory Hole Volcanics

granodiorite

granodiorite porphyry

intrusive rhyolite.

Peppersauce Member of Abrig tion

Three C Member of Abrigo Formation...

tungsten mines.

Mines

volcanic rocks in Cloudburst Formation.-

Mississippian System

Mogul fault $6,10,12,19,23,27,34$, $61,68,70,71,72,76,85,87$

associated and subsidiary faults........... 71

Monolithologic sedimentary breccias in Cloudburst Formation

Morning Star mine.

Morning Star tungsten mine.

Mount Martin

N

Naco Hills

Naco Limestone.

Nugget Canyon. $24,27,35,37,38,39,41,42$

\section{0}

Old Maudina mine

Oracle Ridge.

15,16

Ore deposits, age.

Ouray Limestone

\section{P}

Pediments

Pennsylvanian and Permian Systems.

Peppersauce Canyon

Member of Abrigo Formation alteration by contact metamorphism. minerals stratigraphic section in Nugget Canyon. -

Peppersauce Sandstone

Peppersauce Wash

Physical Features.

Pinal Schist $19,20,21,24,27$

Pioneer Formation disconformity between Barnes Conglomerate Member of Dripping Spring Quartzite

maroon slates

middle member.

origin.

Scanlan Conglomerate Member

upper Member.

minerals

stratigraphic section

Pioneer Quartzite.

Pioneer Shale

Precambrian rocks.
Quartz diorite porphyry..................... $\quad 65$ Quartz monzonite. ....................... 66, 68,70

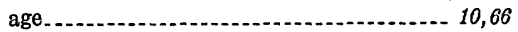
aplite dikes............................... 12 composition......................... 9 minerals.................. 8,66 Quartz monzonite (Oracle Granite of Peterson, 1938) $\ldots$

Quartz veins. .................................. 84 gold-bearing age and origin ............. 80

Quaternary, alluvium...................... 65

gravels...................................... 64

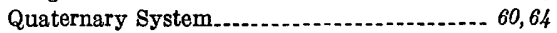

Quiburis Formation............................. 61

\section{$\mathbf{R}$}

Ransome, F. L., cited...... 14, 18, 19, 23, 26, 34,37, 41 Raup, R. B., cited........................ 19

Recommendations for prospecting........... $\quad 87$

Red Hill, diabase dikes......................... $\quad 12$

Redwall Limestone............................ 37

Reed Basin...................................... 55

Relief................ 6, 79

Rhinoceros, fossil............ 60

Ross, C. P., cited.............................. 47

Rubly, G. R., cited. . .

\section{S}

Sacaton Formation.......................... 61

St. Anthony (Mammoth) deposit, age.......- 80

St. Anthony (Mammoth) mine............ 73, 75, 80 production of ore...................... 81 San Manuel deposit............... 45, 47, 49, 55, 68, 75 age........................................ 80 granodiorite porphyry San Manuel fault........ 45, $47,50,51,52,68,73,74,75$ San Manyel Formation...................... 61 San Manuel mine. . . . . . San Manuel porphyry copper deposit......... 81 San Pedro River. flood plain........... 7 San Pedro Valley.................... 60, 61, 62, 74, 77 San Xavier thrust fault....................... 68 Sandstone dikes................... 52 Santa Catalina Formation..................... 26, 27 Santa Catalina Gneiss...................... 27 Santa Catalina Mountains.......... 23, 35, 50, 74, 84 Santa Maria Mining Co.................... 61 Scanlan Conglomerate Bed................... 14, 15 Scanlan Conglomerate Member of Ploneer Formation .......................... 10,14

Schwartz, G. M., cited ......... 9,61,75

Scolithus tubes.................................. 23

Sierrita Mountains....................... 68

Sills, diabase. .

Simons, F. S., cited.................... 48, 49, 59

Smelter Wash

Southern Belle gold mine.................... 27,82 age and origin of the gold-bearing quartz veins. 


\begin{tabular}{|c|c|}
\hline Page & Page \\
\hline $\begin{array}{r}\text { Southern Belle Member of Abrigo Formation- } 27, \\
29,72\end{array}$ & $\begin{array}{r}\text { Troy Quartzite } \\
\text { unconformity between, Apache Group } \ldots \text {._. } 67,69\end{array}$ \\
\hline Southern Belle Quartzite... & Bolsa Quartzite.................. 67, 69 \\
\hline teele, H. J., cited.. & Tucson Wash \\
\hline Stern, T. W., cited.. & Tungsten deposits, age . . . . . . . . . \\
\hline Stoyanow, A. A., cited. & Tungsten mines..... \\
\hline Stratigraphic section in Nugget Canyon, & geology \\
\hline American Flag Formation...... & Turtle fault \\
\hline Bolsa Quartzite. & \\
\hline Martin Formation & $\mathrm{U}$ \\
\hline $\begin{array}{l}\text { Peppersauce Member of Abrigo Forma- } \\
\text { tion }\end{array}$ & Unconformity between, Apache Group and \\
\hline Three C Member of Abrigo Formation & Troy Quartzite \\
\hline $\begin{array}{l}\text { Stratigraphic section in Peppersauce Wash, } \\
\text { Dripping Spring Quartzite }\end{array}$ & $\begin{array}{lr}\text { Galiuro Volcanics and Gila Conglomerate. } & 58 \\
\text { Glory Hole and Galiuro Volcanics..... } 48,49,58\end{array}$ \\
\hline Stratton Canyon. & Troy and Bolsa Quartzites....... \\
\hline $\begin{array}{l}\text { Structure, summary of principal structural } \\
\text { events... }\end{array}$ & Unio.................. \\
\hline Structures. & $\mathbf{V}$ \\
\hline & Veins, quartz............................ \\
\hline $\mathbf{T}$ & 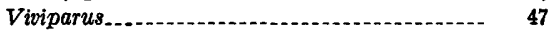 \\
\hline 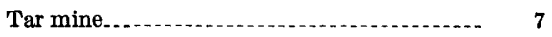 & Volcanic rocks in Cloudburst Formation...-- \\
\hline $51,52,56$ & minerals........ \\
\hline Tertiary System...... & Volcanic rocks in latite flows..... \\
\hline Tertiary(?) System.... & \\
\hline Three C Member of Abrigo Formation........ 27,72 & W \\
\hline in Nugget Canyon... & Warshaw, C. M., analyst.. \\
\hline 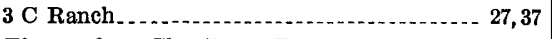 & $\begin{array}{l}\text { Warsitaw, } \\
\text { Whetstone surface......... }\end{array}$ \\
\hline Thrust plate, Cloudburst Formation......... & White, K. E., analyst.... \\
\hline Tombstone surface. & 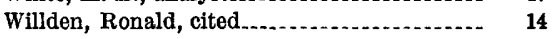 \\
\hline Troy Mountain & Wilson, E. D., cited............... \\
\hline
\end{tabular}



